UNIVERSIDADE DE SÃO PAULO

INSTITUTO DE PSICOLOGIA

LUÍS FERNANDO DE OLIVEIRA SARAIVA

A pedagogização das diferenças sexuais: o cinema como dispositivo educativo

São Paulo

2011 
A pedagogização das diferenças sexuais: o cinema como dispositivo educativo

Dissertação apresentada ao Instituto de Psicologia da Universidade de São Paulo para a obtenção do título de Mestre em Psicologia Escolar e do Desenvolvimento Humano.

Área de Concentração: Psicologia Escolar e do Desenvolvimento Humano

Orientadora: Prof. Dra. Marie Claire Sekkel

São Paulo

2011 
Biblioteca Dante Moreira Leite

Instituto de Psicologia da Universidade de São Paulo

Saraiva, Luis Fernando de Oliveira.

A pedagogização das diferenças sexuais: o cinema como dispositivo educativo / Luis Fernando de Oliveira Saraiva; orientadora Marie Claire Sekkel. -- São Paulo, 2011.

$168 \mathrm{f}$.

Dissertação (Mestrado - Programa de Pós-Graduação em Psicologia. Área de Concentração: Psicologia Escolar e do Desenvolvimento Humano) - Instituto de Psicologia da Universidade de São Paulo.

1. Subjetividade 2. Governamentabilidade 3. Sexualidade 4. Cinema 5. Inclusão social I. Título. 
SARAIVA, Luís Fernando de Oliveira

\section{A pedagogização das diferenças sexuais: o cinema como dispositivo educativo}

Dissertação apresentada ao Instituto de Psicologia da Universidade de São Paulo para a obtenção do título de Mestre em Psicologia Escolar e do Desenvolvimento Humano.

Área de Concentração: Psicologia Escolar e do Desenvolvimento Humano

Aprovado em:

Banca Examinadora

Prof. a Dra. Marie Claire Sekkel (Presidente da Banca e Orientadora)

Instituição: Instituto de Psicologia da USP Assinatura:

Prof. Dr.

Instituição: Assinatura:

Prof. Dr.

Instituição: Assinatura: 
Para Pedro, que não pode prometer ser meu menininho para sempre - mesmo quando fosse grandão - e continuou a cantar tio-tio-tio passarinhadamente. Até hoje. E de tantas maneiras. 


\section{AGRADECIMENTOS}

Agradeço primeiramente à minha orientadora, professora Marie Claire Sekkel, pela aposta e confiança nesses longos três anos. Sua companhia, tranquilidade, gentileza e disponibilidade no inquietante exercício de criação de novos pensamentos foram de tamanha preciosidade nesse percurso.

Ao professor Julio Groppa Aquino, pela generosidade de seus golpes sempre certeiros, capazes de nos tirar o chão e nos fazer estrangeiros dentro da gente. Agradeço também pelo título-presente deste trabalho.

À professora Adriana Marcondes Machado, que me ensinou o ofício de psicólogo e me apresentou o inquietante pensamento foucaultiano. Alguém que desde sempre me inspira e me traz potência.

Ao professor Luiz Fuganti, pela intensidade das segundas-feiras à noite. Intensidade que atravessa todo este trabalho.

A Gê Eisenlohr, maiga querida, que não se cansa de me fazer acreditar no quanto é possível. Agradeço o carinho, as risadas, lágrimas, lições, passeios pela Paulista que nos damos com tanta intensidade.

A Nayara Romero e Fernanda Buckeridge, amigas queridas de tantas histórias, com quem venho compartilhando alegrias, dores, angústias, medos, não apenas do mestrado, mas de toda a tarefa de inventarmos uma vida a se viver.

Às queridas amigas do Taboão, Carol Vieira, Carol Fantin, Gigliana Lima, Margarida Simone, Simone Paggi e Zorah Castanho, por tantos encontros e parcerias que ultrapassaram as durezas de nosso trabalho.

A Martha Pimenta, Mariana Stucchi, Lucimara Bernardo e Aline Brás, amigas queridas que continuam sempre por aqui, por ali, atravessando qualquer distância. 
A toda equipe do CRAS Pirajussara, em especial, Judite dos Santos, Sheila Carneiro e Gleyciara Lima, por tantas trocas e pelas lutas travadas contra a tendenciosa anestesia cotidiana.

Aos parceiros do Conselho Regional de Psicologia de São Paulo, em especial a Carla Biancha Angelucci, por sua maneira de conduzir as coisas, carinho e confiança.

Aos parceiros do Grupo Interinstitucional Queixa Escolar, pela busca incessante em nos potencializarmos. Agradeço em especial a Beatriz de Paula Souza e suas apostas.

A Márcia Moyses, terapeuta que cuidadosamente vem me ensinando a arte de entrar e sair da casinha sempre que necessário.

À minha mãe, Nilce de Oliveira, que, se não me deu um João Bobo quando criança, caprichou em todo o resto. Agradeço pelo cuidado e pela vontade em estarmos juntos.

Ao meu adorado sobrinho Pedro Liev Saraiva, pela impaciência diante de meu sumiço, pelas lutas no sofá e por me fazer querer ir cada vez mais adiante.

E, por fim, agradeço a Bruno Arneiro, pela paciência, atenção, carinho e massagens nesses tempos difíceis. E agradeço mais ainda por, de tempos em tempos, nossos olhares insistirem em se cruzar com tantas intensidades. 
“- - - - - - estou procurando, estou procurando. Estou tentando entender. Tentando dar a alguém o que vivi e não sei a quem, mas não quero ficar com o que vivi. Não sei o que fazer do que vivi, tenho medo dessa desorganização profunda. Não confio no que me aconteceu. Aconteceu-me alguma coisa que eu, pelo fato de não a saber como viver, vivi outra? A isso queria chamar desorganização, e teria a segurança de me aventurar, porque saberia depois para onde voltar: para a organização anterior. A isso prefiro chamar desorganização pois não quero me confirmar no que vivi - na confirmação de mim eu perderia o mundo como eu o tinha, e sei que não tenho capacidade para outro.

(...) É difícil perder-se. É tão difícil que provavelmente arrumarei depressa um modo de me achar, mesmo que achar-me seja de novo a mentira de que vivo..."

Clarice Lispector, A paixão segundo G.H. 


\section{RESUMO}

SARAIVA, Luís Fernando de Oliveira. A pedagogização das diferenças sexuais: o cinema como dispositivo educativo. 2011. 168p. Dissertação (Mestrado) - Instituto de Psicologia, Universidade de São Paulo, São Paulo, 2011.

Com as transformações políticas, econômicas e sociais ocorridas a partir dos séculos XVII e XVIII, tem se intensificado um poder que se ocupa em gerir a vida e lhe extrair ao máximo suas forças, seja na produção de corpos individuais mais produtivos, seja no controle do corpo-espécie da população. Assim, ao mesmo tempo em que se torna hegemônico um modo de subjetivação no qual domina uma interioridade dotada de capacidades, desejos, virtualidades a serem descobertos, há uma crescente preocupação com fenômenos e processos da vida, transformados em taxas a serem medidas e previstas. No encontro entre indivíduo e população, a sexualidade, ponto fundamental na gestão da vida. Nesse contexto, o presente estudo teve por objetivo investigar modos de subjetivação acionados pelo cinema no que diz respeito às diferenças sexuais, fornecendo subsídios para a problematização de práticas ditas inclusivas. Em uma perspectiva teórico-metodológico pós-estruturalista que dialoga com a Teoria Crítica, tomou-se o cinema como um dispositivo educativo e governamentalizante, isto é, uma extremidade na qual o poder se exerce, visando o governo de corpos e da população. Inserido na lógica da indústria cultural, o cinema ensina estilos de vida, maneiras de ser e modos de se relacionar, construindo e legitimando identidades sociais, ao mesmo tempo em que desautoriza outras. A partir da análise de filmes indicados e/ou vencedores do Oscar na última década, percebeuse uma significativa mudança nas formas pelas quais personagens não-heterossexuais vêm sendo apresentados, apontando tanto para uma aparente ruptura com imagens pejorativas e estereotipadas, fomentadoras de preconceitos e exclusões, quanto para a incitação de processos subjetivadores nos quais dominam a domesticação das diferenças sexuais e abafamento de seu potencial contestatório e disruptivo.

Palavras-chave: subjetividade, governamentalidade, cinema, sexualidade, inclusão social 


\begin{abstract}
SARAIVA, Luís Fernando de Oliveira. Pedagogicizing the sexual differences: cinema as an educational device. 2011. 168p. Dissertação (Mestrado) - Instituto de Psicologia, Universidade de São Paulo, São Paulo, 2011.

With the political, economic and social changes from the seventeenth and eighteenth centuries, has intensified a power that engages in life and manage to extract most of their forces, either in the production of individual bodies more productive, be in control of body-species population. Thus, while it becomes a hegemonic way of subjectivity in which one dominates inner endowed with abilities, desires, virtues to be discovered, there is a concern about the processes of life, transformed into rates to be measured and predicted. In the meeting between individual and population, sexuality, is a fundamental point in life management. In this context, this study has the objective to investigate ways of subjectivity regarding to sex differences, supporting the problematization of practices called "inclusive". In a theoretical and methodological poststructuralist that dialogues with Critical Theory, cinema became an educational device and of governamentalization, ie an end in which power is exercised in order to government bodies and the public. In the logic of the culture industry, the film teaches lifestyles, ways of being and ways of relating, building and legitimating social identities at the same time that disallows others. From the analysis of nominated films and / or Academy Awards winners in the last decade, it was noticed a significant change in the ways non-heterosexual characters have been presented, pointing to an apparent break with negative images and stereotypes, that lead to actions of prejudice and exclusion, as for the incitement of subjective processes in which dominate the domestication of sexual differences and smothering of their contesting and disruptive potential.
\end{abstract}

Key words: subjectivity, governamentality, sexuality, cinema, social inclusion 
PARTE I- BASTIDORES

1. CARTOGRAFANDO INQUIETAÇÕES

PARTE II - LUZES

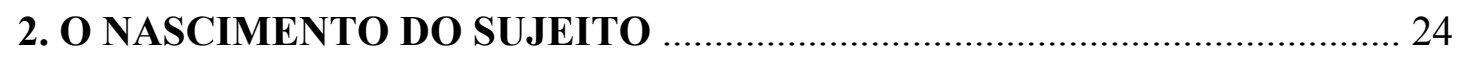

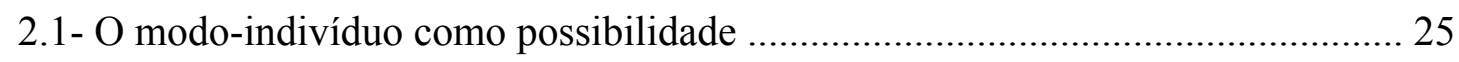

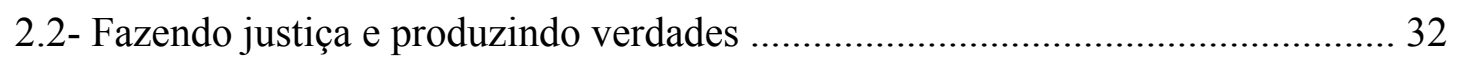

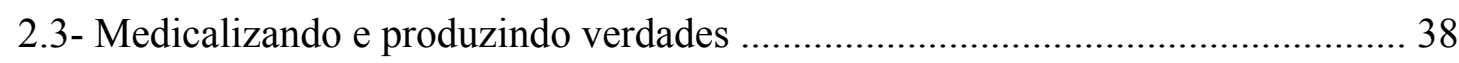

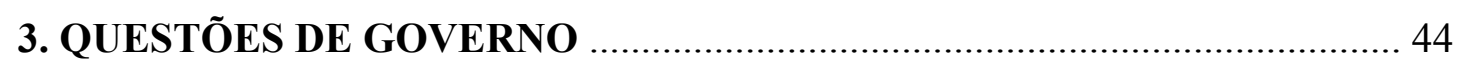

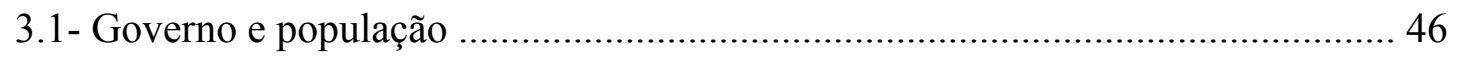

3.2- O governo de corpos e populações: o dispositivo de sexualidade ...................... 54

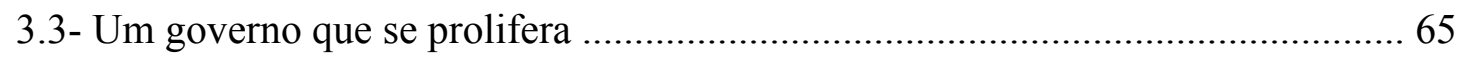

PARTE III - CÂMERA

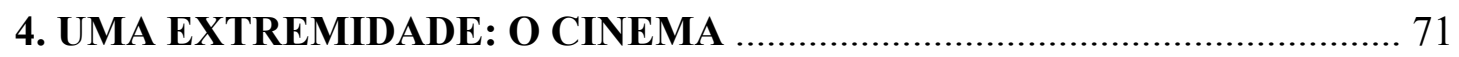

4.1- Um dispositivo da (na) indústria cultural ...................................................... 74

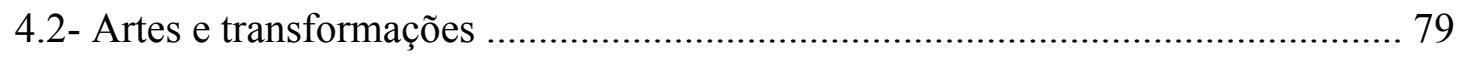

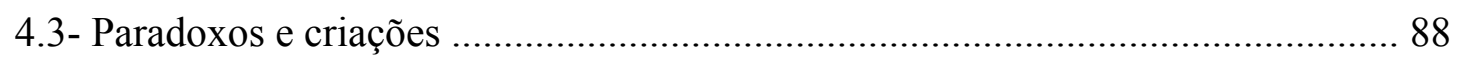

4.4- $(\mathrm{Re})$ Tomando o cinema como extremidade ..................................................... 93

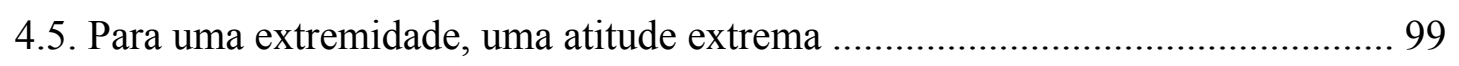

PARTE IV - AÇÃO

5. PEDAGOGIZANDO AS DIFERENÇAS SEXUAIS .................................... 105

5.1 - Primeira Lição: a descoberta de si ................................................................... 110

5.2- Segunda Lição: como sair do armário .......................................................... 116

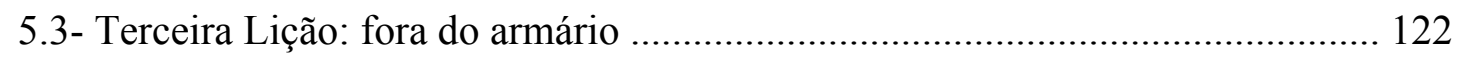

5.4- Quarta Lição: o fim do nomadismo ............................................................. 126

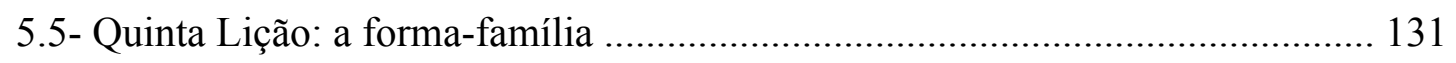

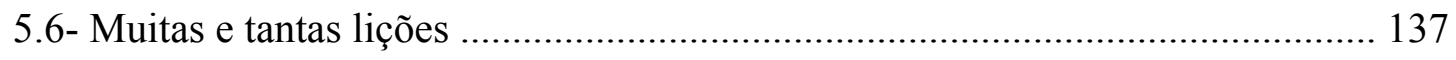


PARTE V - CORTA

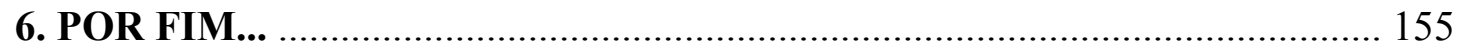

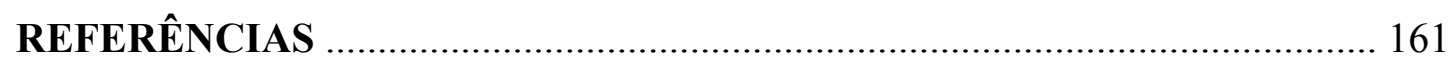

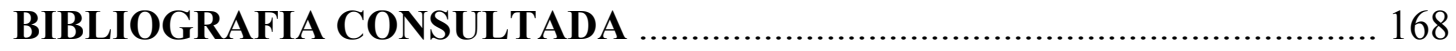




\section{PARTE I - BASTIDORES}




\section{Cartografando inquietações}

Eu hei de ter ao invés de paz inquietação Houvesse paz, não haveria esta canção ${ }^{1}$

Esta pesquisa nasceu de encontros de tamanha inquietação. Uma inquietação inicial com concepções e práticas escolares nas quais são produzidas hegemonicamente corpos e almas adoecidos, faltosos, excluídos. Concepções e práticas que aprisionam diferentes modos de ser, pensar, sentir dentro de uma de um campo marcado por desigualdades e exclusões. Uma inquietação ligada, sobretudo, à maneira como diferenças sexuais vinham sendo vivenciadas, diferenças estas costumeiramente percebidas como desvios, patologias, formas não-naturais e ilegais de sexualidade. Inquietação: no que diz respeito à educação inclusiva, como produzir olhares curiosos diante daquilo que é considerado uma diferença sexual?

No encontro com o pensamento de Michel Foucault, novas inquietações. Momentos de desestabilização, de metamorfose. Entendendo que na produção das diferenças sexuais como desigualdades dominava um certo tipo de saber, saber que engendrava essa produção, como, então, analisar a formação de um certo tipo de saber em termos de poder?

Poder entendido por Foucault (1988, 1995, 2008a) como algo que só existe em ato; uma ação sobre uma ação. Quer dizer, um conjunto de ações sobre ações possíveis; algo que incita, induz, desvia, facilita ou dificulta, amplia ou limita, torna mais ou menos provável. Um conjunto de mecanismos e procedimentos que fala de um campo de relações; o poder é causa e efeito de todas as relações. Algo que não está em um lugar definido e não é uma

\footnotetext{
1 “De amor e paz”, letra de Adauto Santos e Luiz Carlos Paraná, cantado por Mart'nália.
} 
propriedade de alguém, nem algo estável. Uma multiplicidade de correlação de forças, que provém de todos os lugares. Não é uma substância; é verbo. É algo que se exerce, no sentido de buscar conservar a si mesmo, o estado das coisas que o constitui. Não que se funde em si mesmo e se dê a partir de si mesmo; o poder é sempre parasitário. Algo repressivo, então? Não necessariamente. A repressão é apenas um dos aspectos do poder, um de seus efeitos, mas não o principal. O poder é algo positivo, uma ação positiva, que, mais do que encerrar uma ação, busca produzir uma ação. Produtivo: esta é uma de seus principais atributos. Produtivo, pois busca modos de resolver problemas; uma estratégia para um dado momento, em um dado lugar, operando no campo das possibilidades. Quer dizer, torna uma coisa mais possível que a outra. E algo que exige a cumplicidade dos sujeitos.

Uma cumplicidade, pois, falar em poder, implica falarmos na "condução de condutas", no ordenamento de probabilidades, de possibilidades. Ora, para se exercer, o poder requer possibilidades várias; requer, assim, "sujeitos livres", que têm várias possibilidades de conduta, reação, modos de comportamento à vista. Intencional, supõe a possibilidade de resistências. Poder que se distingue da violência, uma situação na qual há uma intensa saturação determinista, uma espécie de coerção pura.

$\mathrm{Na}$ tentativa de controlar acontecimentos aleatórios, isto é, possibilidades, a produção de discursos de modo controlado, selecionado, organizado e redistribuído (FOUCAULT, 1996). Recortes. Daquilo que pode ser dito, visto, feito. Mesmo quando ares de verdade dominam. Discursos são práticas, descontínuas, produzidas com ares de continuidade. Práticas impostas às coisas, inventadas dentro de um campo de possibilidades, quer dizer, possibilitadas a partir de certas condições. Se recortes, produzidos em determinado contexto, pensar as condições para sua emergência, aquilo que há de descontinuidade, as normas pelas quais funciona, seus alvos e aquilo que eles fazem fazer. 
Assim, como pensar a educação inclusiva integrante de relações de poder? Que ações vêm se produzindo sobre quais ações? Que discursos, isto é, recortes, produz?

Perguntas produtoras de desnaturalização. Da educação inclusiva. Dos encontros entre as diferenças sexuais e a escola. Da (pré)suposta potência desses encontros, quase bons em si. Desdobra de objetos-já-dados, naturalizados ao não perguntarmos sua proveniência.

Necessidade, então, de se desnaturalizar a educação inclusiva. Se, de um modo geral, a educação inclusiva é tomada diretamente como um paradigma a ser seguido, um passo atrás se faz necessário. Com isso, um desafio pode se produzir: pensar quais relações de poder instituíram a educação inclusiva como um objeto possível e de que forma foi se tornando possível investi-la de técnicas de saber e de procedimentos discursivos. Perguntas que se reformulam. O que se diz, então, quando se diz "educação inclusiva"?

Pensar tal pergunta significa pensar os procedimentos produtores dos discursos acerca da educação inclusiva e as maneiras como os discursos se organizam e se distribuem. Mais do que pensar o que é esse discurso ou o que diz esse discurso, pensar o que ele faz fazer. No discurso pela defesa da inclusão, pelo que se vem lutando? Qual poder queremos nos apoderar?

O que se diz quando se diz "práticas de inclusão"? O que está em jogo nesse discurso? Desconfianças ao pensar essas perguntas. Uma nova conexão possível: quais os efeitos desses discursos? O que produzem, que realidades acionam? Que campo de forças se quer criar nesse contexto? Que campos se criam?

Foucault (1988), como veremos mais adiante, acompanha mudanças impressionantes em questões relacionadas ao sexo. Do silêncio à incitação em se falar sobre. Uma incitação 
acompanhada de um efeito de que não se fala. Ou de que se fala de algo proibido. Uma incitação a confessar algo que daria acesso a quem somos. Incitação a se falar, sobretudo, daquilo que chamamos de diferenças sexuais. Sexualidades desviantes, pouco "normais". Uma legitimação dessas sexualidades ao longo do tempo, ou de parte delas. Que passagem é esta, da repressão de tais diferenças a sua incitação, da ilegitimidade a uma suposta legitimidade (do lucro, talvez), da censura ao "confessa", à incitação? Aliás, que consenso é este: “educação inclusiva”"? Que consenso é o "aceite as diferenças”?

Ares de desconfiança por essa busca da visibilidade. Que visibilidade permanente é essa que acompanha as tais práticas inclusivas e o tal "respeito às diferenças sexuais"?

Atravessamentos que se cadenciam. Falamos de uma visibilidade que torna algo legítimo, enunciável. Que expõe à dissecação da linguagem e do olhar. O visível se torna também dizível, em procedimentos de classificação, hierarquização. Idéia de que discursos de aceitação das diferenças é também um discurso de domesticação, de docilização dos corpos. Olhar para saber. Olhar para reger. Forças disruptivas que passam a ser colonizadas, abafadas. Normalização. Poder sobre a vida; organização da vida. Mecanismos corretivos. Lei que funciona cada vez mais como a norma. Práticas que gerem a população. Gestão de condutas; condução de condutas. Novas normas, agora modulares; uma flexibilidade que torna todos produtivos, capaz de fazer todos caberem. Regulamentação, ora. Relações que tendem à dominação, à aniquilação de possibilidades de resistência. Sob o argumento de garantia de direitos. De direitos humanos e de sentimentos humanitários (FOUCAULT, 1973 [2003], 1975 [1987], 1988, 1999, 2008a).

No trato às diferenças sexuais (e não apenas), uma ideia costuma ser frequente: a aparente necessidade em se "dar voz" àqueles que são considerados diferentes. Uma ideia de que são oprimidos, vitimizados, estando submetidos a práticas de assujeitamento constantes, sem qualquer possibilidade de resistência. Caberia, assim, o empoderamento dessas pessoas 
para que pudessem falar por suas "próprias vozes", como se essas "próprias vozes" existissem. Que campo de forças é esse que conforma esse jeito de pensar, que produz uma divisão entre dominantes e dominados? Um jeito de pensar que convida à criação de "práticas bem sucedidas", daquelas que interferem naquilo que já é efeito. Se excluído, inclui. Se discriminado, respeitado. Se silenciados, agora com suas “próprias vozes”.

Tomada como verdade, a inclusão, acompanhada da idéia de que as diferenças devem ser aceitas, deve passar a fazer parte do rol das verdades absolutas. "Inclusão", "direitos humanos", "democracia". Palavras de ordem a serem necessariamente seguidas, sem a possibilidade de nos perguntarmos o que se diz quando se diz inclusão, direitos humanos, democracia...

Um outro caminho possível: procurar fazer emergir a produção dos discursos sobre a inclusão no que diz respeito às diferenças sexuais no campo das relações de poder, relações estas, múltiplas e móveis. Da escola para as práticas educativas. Práticas que atravessam todo o campo social. Práticas que dizem respeito à gestão de corpos, de almas e de populações. Não apenas nos bancos escolares.

Nova questão: de que forma forças da vida produzem idéias que vão dar o fundamento para as ditas práticas inclusivas? Aliás, como se desenvolve um saber sobre a inclusão, sobre o "respeito às diferenças sexuais"? Que campos de saber/poder se diagramatizam? Que formas de subjetivação daí emergem?

Necessidade de conhecimento de si. Conhecimento de como entramos em um certo jogo de verdade (a inclusão, neste caso). Acesso ao processo de produção daquilo que se tornou atributo individual. E conhecimento de princípios que são simultaneamente verdades e 
prescrições. Consciência histórica das motivações de nossas conceituações. Conhecimento de campos de forças; forças se dão em movimento; conhecer, então, movimentos. Em movimentos capazes de operar rupturas, transmutações. Movimentos de desnaturalização. Movimentos que implicam em uma investigação sobre como, historicamente, se produziram determinados efeitos de verdade nos discursos e práticas; efeitos estes que não são, em si, nem verdadeiros nem falsos. Desconstrução. Decomposição de verdades, tomadas como naturais e universais. Construção de um muro de pedras soltas.

Conhecer, pois, a economia das relações de poder. Se Foucault, para entender a sanidade, recorreu a seu avesso, à insanidade, penso que o mesmo possa ser feito em relação à educação inclusiva no que se refere às diferenças sexuais. O que significa estar incluído quando se fala em diferenças sexuais? Para isso, ver o que significa ser excluído. Ser excluído parece significar, entre outras coisas, não poder casar, não poder adotar uma criança, não poder ter um relacionamento estável (em termos de lei, por exemplo). Enfim, não fazer aquilo que a norma estabelece, aquilo que uma norma heterocentrista estabelece. O que acontece, então, para que as possibilidades de ruptura com o hegemônico, isto é, formas de resistências, passem a ser entendidas como exclusão? Pensando nas formas de resistência encontradas nesse campo, como o potencial disruptivo que em encontro entre as diferenças sexuais e práticas educativas pode afirmar, como se dá as relações de poder que configuram esse campo de forças?

Perguntas marcadas pelo "como", por um "como se exercem" relações de poder no encontro entre diferenças sexuais e educação. Que condutas vem sendo conduzidas? Como vem sendo conduzidas? Perguntas que nos levem a pensar como se exerce o modo de ação de alguns sobre outros. Para aí, podermos pensar em outras ações possíveis e, assim, em novas economias de relações de poder. 
Perguntas que produzem uma nova problematização. Problematização dos discursos de aceitação às diferenças sexuais presentes em práticas inclusivas (não apenas práticas de educação inclusiva), entendendo que eles são também um discurso de domesticação. A categoria "homossexuais" passa a dizer respeito também a uma forma de colonização das diferenças sexuais. A igualdade formal, estabelecida pela letra da lei, nos mais diversos campos sociais, fala não apenas da garantia de direitos, mas também de formas de colonização, abafamento, domesticação de formas disruptivas das diferenças sexuais.

Educação inclusiva, então, não é meramente um paradigma, uma forma de pensar. É efeito de práticas sociais historicamente produzidas, é efeito de relações de poder. Algo que nos convida a interrogar as redes de articulação estabelecidas entre si, bem como os campos de saber-poder diagramatizados nessas redes, produtores de verdades, naturalizadas. Com isso, poderemos analisar os modos de subjetivação acionados nesses campos de saber-poder. Cabe-nos, então, pensar que tipos de sujeitos vem sendo produzidos pelas práticas de educação inclusiva.

Necessidade de fôlegos outros. Para a sexualidade, restituir seu caráter político. Afinal, Foucault (1988) nos mostra que a sexualidade, enquanto uma "disciplina do corpo", além de uma preocupação individual, se trata de uma questão política, participando da regulação das populações, sendo, assim, um negócio de Estado, de interesse público, dizendo respeito à saúde coletiva, à economia, à capacidade de trabalho, produção de riquezas, enfim, ao presente e ao futuro da sociedade. Enquanto um aparato histórico, a sexualidade está engendrada em uma rede de regulação social, que organiza e modela os corpos. Necessidade de gestão do sexo, inserido, pois, em sistemas de utilidade, regulado para o bem de todos. Sexo não apenas julgado; sexo administrado.

Dessa forma, a sexualidade possibilita controles constantes, ordenações espaciais meticulosas, exames médicos ou psicológicos infinitos; ela se constitui um importantíssimo 
meio de acesso tanto a aspectos privados quando públicos. Esmiuçada, tornou-se chave da individualidade, permitindo o exercício de um biopoder sobre a população, cujo objetivo é vigiar, controlar e regulamentar mais do que os corpos, as populações, de modo a assegurarlhes maior produtividade e docilidade. O biopoder se dá através de tecnologias de autodisciplinamento e de autogoverno exercidas pelo próprio sujeito, sobre si mesmo.

Novo nível de análise possível: como se operam dispositivos biopolitizantes em práticas educativas fora das escolas, no cinema, que tal? Afinal, o cinema é marcado também por algo da ordem educacional (uma educação da população), atravessamento muito mais flexível, modular, "invisível”. Conceito de governamentalidade nos atravessando. E questões vão se tornando coletivas, impessoais, aumentando possibilidades de circular entre elas. A procura por práticas, saberes, relações... Um novo recorte.

Recorte que possibilita a ampliação do campo de análise, em giros englobadores, para recortes outros. Pesquisa como possibilidade de luta. Busca, então, de idéias para lutar. Lutar contra o hegemônico, contra as impossibilidades de processos de diferenciação.

Novos encadeamentos, agora mais estabilizados. Em um contexto no qual muito se fala sobre inclusão, sobretudo no que toca às questões educacionais, a idéia de que as diferenças devem ser aceitas - muitas vezes, custe o que custar - parece tender a uma profunda naturalização. Dificilmente se questionam a serviço de que essa aceitação deva se operar ou quais práticas e concepções são acionadas cotidianamente, tornando-se um discurso a ser repetido, de forma quase sempre monolítica e consensual.

Em um esforço genealógico, um certo estranhamento diante dessa idéia. A busca pela construção de um discurso sobre a aceitação das diferenças sexuais, pensando que 
possibilidade de discurso é essa e em que práticas ela funciona. As diferenças sexuais? Uma ocasião na qual a vida é governada. Uma ocasião na qual movimentos governamentalizantes se dão. Para isso, tomamos o cinema como nosso campo fenomenal. Um dispositivo pedagógico, governamentalizante; uma montagem que opera a pedagogização de corpos e almas. Que também nos ensina como viver. E como ser. E como pensar. E como sentir. E como agir. 
PARTE II- LUZES 


\section{O NASCIMENTO DO SUJEITO}

Para olhos já gastos, o sujeito está posto, está dado: ele está por todos os lados, está nos outros, está em nós. Universal e natural, o sujeito é como um être-lá. Algo pré-existente, transcendental, estratificado, um a priori. Esta parece ser a maneira de toda uma tradição da filosofia e das ciências humanas em entender nossa existência. Tradição que, de tanto se repetir, aparece carregada com grandes ares de verdade e naturalidade.

Jeito de olhar que entende que existimos - assim como as coisas existem - por nós mesmos, em nós mesmos. Ser sujeito significa termos qualidades, adjetivos, tornando necessário o uno, quer dizer, um certo tipo de sujeito individualizado e individualizante, prisioneiro de interioridades e alheio a qualquer contexto mais amplo. Torna-se necessário, assim, a busca por um "em si", aquilo que somos "em si”; nossa "natureza". Um "em si" a ser desvendado, já que supostamente guarda todos os segredos de nossa real existência; um "em si" cheio mistérios, que devem ser acessados para que possamos "descobrir" quem de fato somos.

Mas, como diz Barros (1994), um de nossos maiores desafios é o de desnaturalizar o mundo que nos cerca. E desnaturalizar o mundo que nos entranha. Quer dizer, desnaturalizar quem somos, pondo em questão se somos. Desnaturalizar no sentido de perguntarmos como se deu a proveniência de um objeto - em nosso caso, esse objeto-sujeito - buscando as condições de gestação daquilo que nos aparece como algo já dado.

Desnaturalizar a ideia de sujeito implica pensarmos sua emergência; emergência, esta, singular, efeito de um campo múltiplo de forças, cuja base se dá na dispersão. Desnaturalizar, assim, é fugir à qualquer origem; é traçar genealogias, buscar o acontecimento, o modo como uma coisa é produzida, necessariamente em seu contexto, sua história; história esta que, a cada instante, o funda e o refunda. História sem sentido, mas com 
lutas, estratégias e táticas; uma história onde não encontraremos o sujeito constituinte, apenas a constituição de saberes, discursos e domínios sobre ele (FOUCAULT, 1973 [2003], 1979).

Desnaturalizando a ideia de sujeito veremos que nossa existência como sujeitos é uma invenção um tanto quanto recente em nossa história. Invenção recente e datada: o sujeito é sempre sujeito de cada formação social. O sujeito é, então, um a posteriori, uma entre tantas possibilidades de existência, de produção. Mudança de perspectiva ética e política, como nos falam Monteiro (1997) e Miranda (2005), na busca por outros modos de subjetivação que afirmem a expansão da vida.

Conheçamos, então, que condições tornaram possível o nascimento deste sujeito individuado.

\section{1- O modo-indivíduo como possibilidade}

O sujeito é uma entre tantas possibilidades de produção. Se ele não é ponto de partida, como nos habituamos a pensar, é efeito. Efeito de campos de forças; efeito que faz subjetivada a subjetividade:

Há dois significantes para a palavra sujeito: sujeito a alguém pelo controle e dependência, e preso à sua própria identidade por uma consciência ou autoconhecimento. Ambos sugerem uma forma de poder que subjuga e torna sujeito a (FOUCAULT, 1995).

Foucault é claro: não apenas o sujeito não existe de antemão, como ele se produz em relações de poder. Quer dizer, se produz em relações de forças sobre forças. Mas de quais forças falamos? Conhecer essas forças, assim, significa podermos traçar a história desse tipo de sujeito, as condições que tornaram possíveis sua emergência. 
A fabricação dessa forma-homem que conhecemos - o indivíduo - vem acompanhando as mudanças ocorridas entre os séculos XVII e XVIII. Mudanças que vêm no bojo da cristalização do capitalismo enquanto sistema sócio-econômico dominante em nossa sociedade.

Nesse período, assistimos uma grande aceleração no processo de extinção da sociedade feudal e suas formas de relação patriarcais, já bastante enfraquecidas com as práticas mercantilistas de outrora. Como aponta Barros (1994), várias são as transformações do período: a ascensão da burguesia, o processo de industrialização, a submissão do campo à dominação da cidade (com a crescente possibilidade migratória), crescente divisão de trabalho, intensificação da circulação de riquezas, concentração de meios de produção e imposição de concorrências desiguais. Assistimos, com isso, uma nova configuração social, política e econômica; novas demandas, novos problemas, novas possibilidades de revolta.

A relação com o Estado muda. O Estado, outrora protecionista e intervencionista, passa a ter uma função de apenas manter a ordem necessária para o livre comércio. Direitos e deveres, por exemplo, passam a ser preponderantes diante das diferenças entre as pessoas, sejam elas quais fossem - de classe, idade, sexo, nascimento. Ao mesmo tempo, difunde-se a ideia de que cada pessoa teria a possibilidade de ascensão social de acordo com suas características e esforços - pessoais, individuais, o que nos revela uma ideia de que vivemos em um mundo em que pretensamente todos teriam as mesmas oportunidades.

Parece paradoxal falarmos na produção de pessoas iguais perante a lei e pessoas diferentes em seus esforços. Paradoxo que possui uma importante função:

[o paradoxo] serve para produzir a idéia de que diferença se dá por comparação entre "iguais", por competição entre dois ou mais, mas, sobretudo, como marca de identidade, ponto decisivo numa sociedade que começava por se fundar numa lei que olhava o desempenho individual como determinante do processo de acumulação que 
garantiria a mais valia já ambicionada pelas classes dominantes (BARROS, 1994, p.24).

Observa-se, assim, a emergência da seguinte situação: direitos se confundem com a razão do Estado; há uma coincidência entre esses dois elementos; quer dizer, há uma coincidência entre a razão do Estado e os indivíduos em sociedade. Falamos, então, da combinação de técnicas de individualização e dos procedimentos de totalização operada pelo Estado Moderno. Estado e indivíduo vêm juntos, respondendo a necessidades políticas, econômicas e sociais.

Mudanças macropolíticas, que destacam a individualização - ou o modo-indivíduo, como chama a autora - como principal modo de subjetivação, principal processo de produção de subjetividades. Quer dizer, falamos de uma subjetividade que não guarda nada de transcendência ou essência; falamos de uma subjetividade fabricada, produzida. Quer dizer, uma forma-homem, em-si-mesmada, individualizada, que não passa de um modo de ser, pensar, sentir, estar no mundo, que é fabricado. Nessa perspectiva, modos de subjetivação dizem respeito a

\begin{abstract}
processos que tanto construirão certos objetos de interesse, quanto conformarão modos de existir. Quando nos referimos, portanto, a modos de subjetivação, os estamos tomando em seu sentido intensivo, isto é, enquanto maneira pela qual, a cada momento da história, prevalecem certas relações de poder-saber que produzem objetossujeitos, necessidades e desejos (BARROS, 1994, p.24).
\end{abstract}

Falar em modos de produção de subjetividade ou em processos de produção de subjetividades, implica em pensarmos a subjetividade como algo maquínico, que é construído, que não é um já-dado, nem um em-si, mas que é fabricada nas grandes máquinas sociais, 
midiáticas, lingüísticas... A subjetividade equivale a certo modo de funcionamento (não estrutural), uma forma (GUATTARI \& ROLNIK, 2005). E o indivíduo, tal como o concebemos hoje, não passa do resultado de um longo processo de fabricação de um certo tipo de subjetividade, produzido entre os séculos XVII e XVIII e que marca, até hoje, nossos saberes e práticas.

Se cada sociedade produz o sujeito que lhe interessa, vemos que o modo-indivíduo é produzido pelo capital a serviço do capital; é um efeito-capitalismo, isto é, produz-se junto, é essencial na produção deste sistema sócio-político, há uma continuidade entre o sujeito e este. E como modo dominante, o modo-indivíduo faz prevalecer certas relações de poder-saber que produzem objetos-sujeitos, necessidades e desejos. Falamos de um modo de subjetivação característico de uma sociedade de sequestro, de sequestro da vida; uma sociedade que transforma a vida em corpos e força de trabalho. Para isso, toda uma rede de sequestro se torna necessária, incluindo, produzindo corpos organizados e eficientes; rede que extrai sujeitos e indivíduos de uma massa social; rede que responde à necessidade de produzir homens que se conectem ao trabalho.

Tratar a subjetividade desse modo maquínico, histórico, não transcendental, nos faz pensar como se deu sua constituição dentro de um campo de saber. Afinal, o sujeito é sempre sujeito de cada formação social, formação esta, de saber e de poder.

Para Foucault (1973 [2003], 1979), saber é o campo da forma; não é apenas o campo da ciência, sendo também campo da opinião, da ideologia, de usos e costumes, de crenças; trata-se, enfim, de toda uma zona de formalização. Uma formalização que responde ao contexto onde se opera; assim, cada sociedade acolhe certos discursos e os faz funcionar como verdadeiros. O saber é um integrador de forças difusas, que compõem o poder; o saber é algo que tece, que alinhava, estratifica, implicando uma dupla dimensão: discursos e sensibilidades. 
O saber é sempre funcional, da mesma forma que o poder. É um efeito efetivo, é operatório; trata-se de uma dimensão formadora. O saber é parte do próprio poder, é integrador, afirma um certo tipo de poder necessário para uma sociedade. Ao mesmo tempo, é o diagrama de poder que determina as condições de dizibilidade e visibilidade de cada época. Assim, saber e poder estão imbricados.

O que vemos, a partir dos séculos XVII e XVIII é a emergência de toda uma vontade de saber a respeito do homem. Uma vontade de conhecer; conhecimento que diz respeito a uma função da existência; quer dizer, conhecer é fazer a vida funcionar de certa maneira; é um conjunto de ferramentas que fabrica as coisas; é, assim, uma prática, não uma teoria.

Nesse sentido, o nascimento do sujeito se relaciona com um certo domínio do saber, que, de acordo com a configuração de forças que estabelece, produz um certo tipo de sujeito, de objeto e de modo de conhecer. É dessa forma que o modo-indivíduo emerge.

E é no campo de saber-poder da sociedade disciplinar que o modo-indivíduo emerge (FOUCAULT, 1975 [1987]). Sociedade na qual opera uma forma de poder preocupada com a vida. Se, até então, nas sociedades de soberania (aquelas anteriores ao Estado democrático moderno - sociedades feudais e Estados Nacionais dos séculos XV e XVI), já se operava controle sobre a vida, este ainda era um tanto quanto incipiente, por mais se efetuar fora dos corpos. O poder do rei dizia respeito a deixar viver e fazer morrer: quando o poder não tolerava algo, ele eliminava.

Nas sociedades disciplinares, uma nova situação se produz: trata-se de não desperdiçar vidas. Trata-se de adestrá-las, permitindo retirar e se apropriar mais e melhor de suas forças. O poder disciplinar, então, funcionará de modo concreto e abstrato, buscando sempre formar indivíduos, específicos, portadores de certas características e capacidades. Um poder que opera na família, educação, saúde, segurança, forças armadas, na prisão dispositivos que se alternam e se sucedem de forma a garantir a efetuação do poder; um poder 
que tende à generalização, que ultrapassa os muros de grandes estabelecimentos fechados e se ramifica por diversas práticas sociais. Um poder permanente. Em todas as instituições, uma mesma função: extrair forças de outras forças, conectando-as para multiplicá-las e utilizá-las. Um caráter functivo.

Domina uma atenção dedicada ao corpo, a um corpo manipulável, modelável, treinável e cujas forças podem se multiplicar, enfim, um corpo que pode se tornar dócil, capaz de se submeter, transformar e se aperfeiçoar. Para isso, uma intensa atenção a cada detalhe do corpo, através de coerções sem folga, visando sempre uma maior eficácia. Forças não podem ser desperdiçadas. É disso que se tratam as disciplinas: "métodos que permitem o controle minucioso das operações do corpo, que realiza a sujeição constante de suas forças e lhes impõem uma relação de docilidade e utilidade” (FOUCAULT, 1975 [1987], p.126).

Anátomo-politicamente, o corpo ganha vida, se torna orgânico, natural, sendo esquadrinhado, desarticulado, recomposto; não se perde o mínimo detalhe (ou, ao menos, não se deve perder). Recomposto também em um conjunto relacional com outros corpos. Corpopeça. Ao mesmo tempo o corpo é dissociado do poder, isto é, de sua possibilidade de agir sobre as ações que lhe são impostas, a partir de técnicas sutis, que almejam a invisibilidade, ao mesmo tempo em que tornam os indivíduos permanentemente visíveis.

Esse jogo entre visibilidade do sujeito e invisibilidade do controle associa-se à ideia de panoptismo, uma forma de poder característica da sociedade disciplinar, derivada do Panopticon $^{2}$, de Bentham, cujo efeito mais importante é

\footnotetext{
${ }^{2}$ O Panopticon refere-se ao projeto arquitetônico idealizado por Jerery Bentham, no fim do século XVIII. "Era um edifício em forma de anel, no meio do qual havia uma torre no centro. $\mathrm{O}$ anel se dividia em pequenas celas que davam tanto para o interior quanto para o exterior" (FOUCAULT, 1973 [2003], p.87). O princípio panóptico se fundava na presença de um vigilante na torre central, cujo olhar poderia atravessar cada cela por completo, sem, entretanto, ser visto por aquele que lá se encontrava. Uma forma arquitetônica que poderia ser utilizada por diversas instituições - escola, prisão, hospital, fábrica - sempre possibilitando uma vigilância e controle contínuo daqueles que se encontravam nas celas.
} 
induzir no detento [indivíduo] um estado consciente e permanente de visibilidade que assegura o funcionamento automático do poder. Fazer com que a vigilância seja permanente em seus efeitos, mesmo se é descontínua em sua ação; que a perfeição do poder tenda a tornar inútil a atualidade de seu exercício; (...) enfim, que os detentos [indivíduo] se encontrem presos numa situação de poder que eles mesmos são os portadores (FOUCAULT, 1975 [1987], pp.177-178).

O Panopticon, mais do que uma estrutura arquitetônica a ser empregada em estabelecimentos prisionais, hospitalares, escolares, fabris, entre outros, se mostra um mecanismos composto também (e talvez sobretudo) de ramificações, de dispositivos ramificados, cuja função é "melhorar o exercício de poder tornando-o mais rápido, mais leve, mais eficaz, um desenho das coerções sutis para uma sociedade que está por vir” (p.184).

Técnicas que tornam difícil ver como os indivíduos são distribuídos no tempo e no espaço, a busca por indivíduos em seus lugares e tempos (adequados) e por lugares e tempos para cada indivíduo (adequado). Difícil ver como eles são distribuídos em suas relações, que, como os lugares ocupados, devem ser também funcionais. Difícil ver como os indivíduos são distribuídos de forma normativa.

Indivíduos serializados, anônimos, normalizados, articulados de acordo com sistemas hierárquicos, de valores e de submissão. Indivíduos cuja força deverá ser extraída ao máximo e ao menor custo. Indivíduos úteis. Indivíduos auto-regulados. Ou que assim desejem. "Espontaneamente". É isto que nasce.

Ao mesmo tempo, universaliza-se o psiquismo, normatizam-se e patologizam-se outros modos de viver. Vejamos agora o nascimento do sujeito a partir de dois discursos distintos e que se entrelaçam: o discurso judicial e a medicina, discursos estes que hegemonicamente têm produzido formas de nos conhecermos na condição de sujeitos. 


\section{2- Fazendo justiça e produzindo verdades}

Foucault, em sua investigação sobre os modos pelos quais os seres humanos se tornaram sujeitos, destaca a função do campo judicial nesse processo de fabricação de subjetividades (1973 [2003], 1975 [1987], 1979). É o campo da justiça que destaca o limite do tolerável, do suportável, do permitido - sejam comportamentos ou discursos sociais, limite sem o qual a sociedade se enfraqueceria. Limite, então, que também dirá que tipo de sujeito é tolerável, suportável, permitido. Limites que foram se alterando ao longo do tempo - em novos regimes de saber-poder, produzindo e conformando a forma de sujeito que conhecemos.

A partir dos séculos XII e XIII, vemos renascer uma outra maneira de se fazer justiça: o inquérito. Até então, durante a Alta Idade Média, dominava uma certa regulamentação do litígio entre os indivíduos, a partir do velho Direito Germânico, através do qual a justiça se dava por meio de jogos de prova, de força - jogos não lógicos nem demonstrativos.

O estabelecimento de uma ação penal se dava de forma simples: alguém poderia se apresentar como vítima de um dano e reclamar a seu adversário (aquele que teria sido o responsável pelo dano) algum tipo de reparação; a liquidação judiciária se daria, então, em uma espécie de duelo entre eles, em uma forma regulamentada e ritualizada de guerra. Esse duelo produzia, assim, o direito, não a verdade. Provava-se a força, a importância de quem dizia, não a verdade. Há sempre um vencedor e um vencido, a partir de um efeito de justiça que é produzido, não na suposta descoberta de uma verdade.

Nessa forma de fazer justiça, sempre era possível novas vinganças e revanches, que poderiam se dar continuamente. Era possível também se interromper essa série de vinganças, a partir de acordos, feitos juntos à figura de um árbitro - responsável em observar apenas se 
as regras estabelecidas estavam sendo seguidas, não decidindo absolutamente nada nem estabelecendo qualquer tipo de sentença.

Ainda, a noção de falta não operava no velho Direito Germânico. Havia dano e vingança; nada de culpa ou falta moral; o indivíduo acusa o outro por ter sofrido um dano, não por ressentimento, achando que o outro é culpado.

O que vamos assistir entre os séculos XII e XVIII são intensas transformações na maneira de se fazer justiça, com a criação de novas práticas e procedimentos, trazidos com o nascimento do inquérito. Nascimento que sempre se dá avizinhando a formação do Estado. Segundo nascimento, já que esta era uma forma de fazer justiça que já operava entre os gregos, na Antiguidade, mas um nascimento "mais obscuro e lento, (...) que obteve um sucesso bem mais efetivo que o primeiro" (FOUCAULT, 1973 [2003], p.55).

O inquérito consiste em uma prova de razão, não mais de força. Uma outra forma de produzir a verdade e fazer a justiça, operando uma separação entre saber e poder. O que importa agora não é simplesmente reparar um dano causado e, sim, descobrir a verdade por trás desse dano. Cria-se a ideia de "fato", algo que aconteceu "de fato" e não se sabe; algo que se precisa saber, descobrir. Para acessar o que se passou, torna-se necessária a presença de alguém com autoridade suficiente para reapresentar o que sucedeu. Surge a figura da testemunha - não mais aquela da regularidade de um procedimento nas provas de força, mas aquela que viu e ouviu um fato. Desloca-se o poder do soberano para o povo, afinal, qualquer um pode ter essa autoridade, não apenas quem tem força ou importância; a verdade não é feita mais por quem diz, está no que é dito, está no enunciado (não mais na enunciação). Cria-se, então, a ideia de um saber neutro, universal, isento de paixões e parcialidades.

O inquérito estabelece um ponto de vista que quer escapar dos pontos de vista, configurando-se um mediador para se acessar a verdade. Se antes a relação envolvia apenas duas partes, o inquérito traz uma terceira instância, que vai destacar uma posição superior a 
um dos lados. Trata-se do ponto de vista do poder, da figura do soberano, que se sente também lesado, ao alegar que o dano provocado constitui uma infração, isto é, um dano contra a razão de Estado, contra suas leis. Assim, é o poder soberano quem se sente lesado e vai exigir reparação, na figura do procurador.

Com novos fôlegos, o inquérito se torna uma ação pública para o confisco de riquezas, mostrando-se um negócio extremamente rentável; estabelece verdades, mas não apenas; possibilita também o acúmulo de riquezas e de poder. Falamos, então, de práticas judiciárias que aceleram a circulação de riquezas, em uma época em que o comércio era escasso. Interroga, então, aquele que quer confiscar.

Um outro aspecto do inquérito também chama a atenção: o inquérito já era praticado hegemonicamente durante a Alta Idade Média, mas em meios religiosos. Esse inquérito cumpria, além de funções administrativas - sabendo como vinham sendo administrados os bens da Igreja - verdadeiros interrogatórios da alma se davam, com práticas confessionárias. Buscavam-se, em nome de Deus e da salvação - ordens, estas, transcendentes - pecados e faltas morais; quer dizer, tratava-se de uma forma de inquirir onde o que interessa é vasculhar os desejos da alma.

Essa concepção também se aliará ao inquérito judicial, trazendo a noção de pecado moral àquilo que é cometido; a falta espiritual ligada à noção de infração. Um “olhar tanto sobre os bens e as riquezas, quanto sobre os corações, os atos, as intenções, etc" (FOUCAULT, 1973 [2003], p.71). Vemos, assim, um processo de subjetivação que se dá acompanhado da interiorização da falta, o gerenciamento e controle das almas. O procurador do rei passa, então, a procurar estabelecer se houve um crime, que crime foi este e quem o cometeu. Mas, antes de tudo, o procurador é os olhos do rei, olhos que vigiam atentamente a população em suas infrações cometidas e naquilo que pode vir a cometer. 
O inquérito, então, constitui uma expansão do poder soberano, não uma mera evolução da justiça, uma racionalidade. Não é um conteúdo, mas uma forma de saber; uma forma de descobrir uma verdade oculta; uma pergunta pela verdade que já se dirige à alma, por querer descobrir essências. E que já aponta para uma vontade de gerenciamento de virtualidades, a partir da descoberta da falta moral cometida. Trata-se, assim, de uma determinada maneira do poder se exercer; estatização da justiça penal; uma forma de se governar.

Do dano à falta moral. Da reparação por vingança à descoberta de um fato. Do cometido à possibilidade de vir a cometer. Estes são desdobramentos que vão se intensificar a partir do século XVIII, em novas formas de se operar a justiça. Formas características da sociedade disciplinar que ali emergia.

Na França do século XVIII, aconteceu uma importante reelaboração teórica da lei penal, onde se propunha a separação do crime/infração daquilo que era considerado falta moral/religiosa. Quer dizer, propunha-se separar aquilo que foi, por longos séculos, sendo aproximado pelo inquérito. Nessa reelaboração, a infração passaria a dizer respeito a uma ruptura com a lei, isto é, com a lei que fora explicitamente estabelecida, contratada socialmente. Assim, uma infração só existiria se houvesse uma lei já estabelecida.

As leis, por sua vez, se estabeleceriam a partir da utilidade que apresentassem para a sociedade. É isto que determinaria uma boa lei: ser útil, sem se remeter a leis naturais, religiosas ou morais. Seria considerado infração, nesse contexto, aquilo que é nocivo à sociedade, que a danifica. Logo, o criminoso é um inimigo social, devendo reparar os danos que cometera, a partir de quatro possibilidades de punição: a deportação, a humilhação pública, o trabalho forçado e a pena de talião.

Se o sistema penal projetado era este, o que se efetivou foi completamente diferente. Cada vez mais a legislação se distancia de sua utilidade social, aproximando-se de um 
ajustamento diante do indivíduo. Isto é, o sistema penal passa a ter em vista "menos a defesa geral da sociedade que o controle e a reforma psicológica e moral das atitudes e do comportamento do indivíduo" (FOUCAULT, 1973 [2003], p.85).

Nesse sentido, as punições então propostas ou não foram coladas em prática ou logo caíram em desuso. Buscam-se penalidades que operem controles, não sobre o que um indivíduo fez, mas "no nível do podem fazer, do que são capazes de fazer, do que estão sujeitos a fazer, do que estão na imanência de fazer" (p. 85). Uma penalidade que controle virtualidades, faltas morais virtuais, que podem vir a acontecer; penalidade que controle periculosidades. Passa a dominar, então, o aprisionamento, uma penalidade até então tratada de modo marginal, quase sem nenhuma justificação teórica.

Assistimos a diversos poderes laterais, instituições responsáveis pelo controle penal punitivo dessas virtualidades que os indivíduos apresentavam. Tempo da emergência da ortopedia social, feita pela polícia, por instituições médicas, psicológicas, pedagógicas, instituições que se estatizam de forma crescente. Uma certa ramificação do poder, ramificação esta que se relaciona com o Panopticon de Bentham.

A ideia de uma forma arquitetônica na qual indivíduos encarcerados - fixados em um determinado lugar - poderiam ser constantemente vistos, sem, entretanto, verem aquele que os observa, parece ter deixado de ser uma utopia. Ora, o Panopticon se baseia (e produz, ao mesmo tempo) em uma inspeção e vigilância constantes, em um exame de indivíduos que não cessa, buscando delimitar suas virtualidades. Uma atenção que se faz continuamente necessária; um olhar potencialmente minucioso, que esmiúça. Um olhar alerta em toda a parte. Uma vigilância que vigia e produz um saber sobre o vigiado; uma vigilância que se apoia em registros permanentes. Um saber normativo, que determina se alguém se conduz da maneira devida ou não, determinando o que é ou não normal. Uma forma de poder que vigia, controla e corrige. 
Uma vontade de vigiar que responde a necessidades sociais, trazidas com a urbanização e o aumento demográfico. Ainda, respondiam a necessidades econômicas: com o (novo) capitalismo, novas formas de acumulação de riquezas, agora na forma de estoques e mercadorias, expostas, à mercê de qualquer um, podendo ser roubados. E respondiam a necessidades políticas, haja visto as novas possibilidades de revoltas populares.

Vontade de vigiar que também vinha de baixo; vinha do controle social exercido por grupos espontâneos de pessoas que se propunham a manter a ordem e mesmo pelas lettres-decachet solicitadas espontaneamente ao monarca francês para regulamentar a moralidade cotidiana. Vale ressaltar que é justamente essa prática para-judiciária, na qual o rei ordena algo a alguém a pedido de um súdito (um marido traído, uma família que quer se livrar de algum de seus entes...), que possibilitarão a emergência da prisão. As lettres-de-cachet estabeleciam como penalidade o aprisionamento de um indivíduo, não apenas como forma de punição, mas como forma de corrigir o indivíduo.

Vemos, então, uma crescente vontade em transformar os indivíduos. Mas uma transformação baseada não necessariamente naquilo que ele fez; uma transformação que se baseia nas possibilidades em vir a fazer. Em outras palavras, podemos dizer que a questão da sociedade disciplinar diz respeito a como controlar o desejo em sua virtualidade; diz respeito, então, a como prevenir. Não necessariamente em instituições de sequestro, como a fábrica, escola, hospital, convento, prisão; sua carga econômica é muito elevada. Busca-se, assim, manter as funções dessas instituições - fixar os indivíduos em aparelhos de normalização, controlar/formar/valorizar seus corpos, extrair a totalidade de seu tempo, visando sempre o aumento de suas forças produtivas e de sua utilidade - agora também maneiras mais capilares.

Na necessidade de se produzir um homem que se autocontrole, que traga o panóptico consigo, produze-se uma situação paradoxal: ao mesmo tempo em que o sistema jurídico vigente na sociedade disciplinar qualificam o indivíduo como um sujeito de direitos (segundo 
normas universais), as disciplinas buscam caracterizar, classificar, normalizar, fixar, hierarquizar os indivíduos, o que, muitas vezes, faz com que esse caráter universal do direito seja desqualificado e invalidado. É por isso que Foucault (1975 [1987]) considera que nas disciplinas há um certo contradireito.

Na busca por essências e virtualidades, o exame, então, serve para, de alguma forma, também determinar que indivíduo e qual direito ele tem. Deixa de lado a qualificação penal do ato cometido por alguém; individualiza-se o sujeito. Assim, o exame serve também para esmiuçar aquele que comete uma infração, propondo mais que uma punição, uma correção, uma terapêutica, uma normalização, enfim uma ortopedia à alma faltosa.

\section{3- Medicalizando e produzindo verdades}

Em tempos de disciplina, a medicina também sofrerá intensas transformações. Transformações ocorridas no bojo da constituição do chamado olhar clínico (FOUCAULT, 1980 [2006]). Um olhar que implica iluminação e sombreamento da realidade; um olhar que traz consigo um regime de luz que inventa algo que é visto e alguém que vê. Assim, o olhar médico que vai se constituindo ao longo do século XVIII é um olhar que se guia por um mundo de constante visibilidade. Um mundo visível - visível por ser sido operado um recorte e reagrupamento desse mundo - que se torna também dizível - em termos de uma ciência positiva.

$\mathrm{Na}$ então medicina das espécies - antecessora cronológica à medicina clínica - o imperativo médico dizia respeito a classificar; classificar doenças que tinham existência própria. Domina um olhar que busca detalhes que falem da história - daquilo que pode se dar ao olhar. Quer dizer, esse olhar médico baseia-se em uma experiência histórica, aquela que pode ser vista, e não em um saber filosófico, que põe em questão origens, princípios e causas. 
Nesse contexto, a principal perturbação ao olhar do médico é trazida justamente com e pelo próprio doente. Suas disposições, sua idade, seu modo de vida, enfim, sua história pessoal, configuram espécies de acidentes diante da essência da doença. Assim, na busca pela verdade, o médico deve abstrair o doente. Seu olhar se dirige, não ao corpo concreto, mas a intervalos e lacunas, nos quais poderá distinguir a essência de uma doença.

Vemos aí a presença de um sujeito, que deve ser anulado de forma a não interferir no real conhecimento da doença. O indivíduo é, então, uma confusão a ser neutralizada. Condição parecida com a do médico, que, na busca por objetividade, deve se abstrair da relação, para que possa acessar a essência do quadro patológico:

Estranha característica do olhar médico; ele é tomado em uma espiral indefinida: dirige-se ao que há de visível na doença, mas a partir do doente, que oculta este visível, mostrando-o; consequentemente, para conhecer, ele deve reconhecer. E esse olhar, progredindo, recua, visto que só atinge a verdade da doença, esquivando-se e permitindo ao próprio mal realizar, em seus fenômenos, sua natureza (FOUCAULT, 1980 [2006], pp.8-9).

Falamos de um olhar qualitativo, que deve se ater às sutilezas das qualidades, das diferenças, às tenuidades das variantes. Um olhar que deve deixar a doença acontecer, "naturalmente", para que a possa de fato ver. Um olhar que anula o sujeito; anula justamente por já o supor.

Nesse tipo de medicina, a doença é estranha ao espaço social, que descaracterizaria sua essência. Entende-se, então, que o melhor a se fazer diante de uma doença era deixá-la “acontecer", desenvolvendo-se e desaparecendo da mesma forma que surgira. O local mais adequado para isso seria justamente o espaço doméstico, a família, não a artificialidade do hospital, que, à época, destinava-se à assistência dos pobres. Seguindo uma lógica de que, internado, apenas o doente se beneficiaria de seus cuidados, deixando sua família às mínguas, 
defende-se a assistência domiciliar, que, de alguma forma, amparasse também sua família. Falamos, então, da necessidade de um projeto estatal para a medicina.

Com as mudanças sociais ocorridas ao longo do século XVIII, sobretudo com a crescente concentração populacional nas cidades, passa a se constituir uma medicina que se atará às epidemias. $\mathrm{O}$ foco do olhar médico desloca-se, então, da busca de circunstâncias - e não para o problema do contágio - para a ocorrência de uma epidemia: "a essência da epidemia não é a peste ou o catarro: é Marselha em 1721, é Bicêtre em 1780, é Rouen em 1769” (FOUCAULT, 1980 [2006], p.23-24).

Tratar de um “indivíduo de cabeças múltiplas mas semelhantes" (p.25), esse fenômeno coletivo - ou um fenômeno singular e nunca repetido, percebido de forma coletiva - passa a requerer uma outra organização, com médicos e cirurgiões designados para acompanhar - observar e relatar - epidemias em cada subdelegação. Agora, um olhar outro, atento, coercitivo e já prescritivo:

Só poderia haver medicina das epidemias se acompanhada de um polícia (...); seria necessário que depois de um estudo detalhado de todo o território, se estabelecesse, para cada província, um regulamento de saúde para ser lido na missa ou no sermão, todos os domingos e dias santos, e que diria respeito ao modo de se alimentar, de se vestir, de evitar doenças, de prevenir ou curar as que reinam (p.26).

Mais uma vez, a medicina ganha fôlego enquanto negócio de Estado. Um negócio que se ramifica cada vez mais e que traz agora um olhar que tende para o infinito, que percorre todo e qualquer acontecimento. Um olhar que vê, informa, controla e coage. E que se esparrama por aí, por situações comuns, cotidianas. Que percorre o tempo e faz cruzar informações, cadenciando-as. Agora, 
o espaço médico pode coincidir com o espaço social, ou melhor, atravessá-lo e penetrá-lo inteiramente. Começa-se a conceber uma presença generalizada dos médicos, cujos olhares formam uma rede e exercem em todos os lugares do espaço, em todos os momentos do tempo, uma vigilância constante, móvel, diferenciada" (FOUCAULT, 1980 [2006], p.33).

Dentro dos hospitais - que voltam a ser valorados, seja para o ensino, seja para cuidados mais complexos - e fora deles. Mais uma vez, pressões vindas de baixo se dão, afinal os indivíduos aprendem muito bem a lição de que devem ter conhecimentos em medicina, ao mesmo tempo em que reclamam a presença de médicos, adequadamente formados e que se contrapusessem a charlatães. Uma presença generalizada que fala de um desejo da medicina - desejo compartilhado socialmente - em ocupar todo o espaço social para dele varrer a doença, tornando, de alguma forma, a própria medicina desnecessária com o tempo. A luta contra a doença passa a dizer respeito também a uma luta contra maus governos; cabe ao médico subsidiar legisladores e cidadãos na construção de uma sociedade livre, “em que a juventude está nua e a idade não conhece invernos” (p.37). Quer dizer, produzir estados conscientes - conscientemente medicalizados - que assegurem o funcionamento automático do controle; quer dizer o desejo da medicina é operar o panoptismo.

A medicina passa a dizer respeito ao homem saudável, definindo quem é o homemmodelo. De forma normativa, legisla sobre o equilíbrio da vida, regendo relações físicas e morais adequadas para os indivíduos nas sociedades em que vivem. Da bipolaridade saúdedoença, em breve a medicina tomará por ter território o binômio normal-patológico. E essa definição entre o que é ou não normal servirá de base para a constituição das ciências humanas e da saúde. 
Cada vez mais, o olhar médico não se contenta em constatar, mas em descobrir. Um olhar que vê, pode dizer e ensinar. Um olhar que sabe e decide, podendo, portanto, reger. Um olhar que vela destinos. É isso que passa a acontecer: um olhar que vê, isola, reconhece diferenças e semelhanças, agrupa, classifica e determina verdades, as dispõe, a partir de concepções de normalidades e de desvios.

Um olhar que ganha forças ao passar a considerar as incertezas daquilo que vê, a partir do uso da estatística, uma espécie de soma de graus de certeza, quer dizer, de probabilidades. Cálculos e antecipações. Disciplinas. Um olhar que deixa de ser um redutor, configurando-se um fundador do indivíduo em sua qualidade irredutível. Um olhar que organiza uma linguagem racional em torno do indivíduo, que produz um corpo doente no corpo do doente.

Um olhar que tateia, que vasculha profundezas e causas, um olhar que também se debruçará para órgãos. Mais uma vez, o corpo do doente é abstraído, agora visto através do corpo após a morte, corpo que pode ser aberto e estudado e fornece verdades a serem utilizadas na leitura de sintomas. Uma morte que retorna à vida na tentativa de se ler aquilo que há justamente de morte. Com essa nova maneira de olhar, uma certa cobrança à morte pela vida e pelas doenças. Olha-se a morte para cobrar a vida, logo esse olhar verá a morte e a doença como aquilo que não deveria acontecer. Desvios, com essências desviantes. A atenção agora se dá diante do organismo, vivo, não mais a sintomas, órgãos ou cadáveres.

Mais do que o abandono de teorias e velhos sistemas, o que marca essa nova medicina é essa reorganização formal e em profundidade. Reorganização do fenômeno patológico e de sua articulação com o organismo. Uma reorganização que possibilita um novo discurso sobre a doença e sobre o indivíduo. Mas, como aponta, Moysés (2001), "reajustes de olhar, mudanças de foco, de local, representam mudanças conceituais importantes, porem 
jamais cortes epistemológicos. Sem rupturas, o método clínico atual traz em si elementos de todos os que o procederam" (MOYSÉS, 2001, p.141).

O que vemos, dessa maneira, é uma crescente função política da medicina, que também pode ser desdobrada para outras ciências humanas e da saúde, entre elas, a psicologia. Uma função política que se estende indefinidamente pelo corpo social, atravessando-o e tomando-o como próprio de seu campo de ação. Ações que esquadrinham corpos individuais e os ultrapassam, atingindo o corpo da população. Ações que serializam, normalizam, articulam, que extraem forçam e buscam a maximização da vida. Uma nova forma de gerir a vida. 


\section{3- Questões DE GOVERNO}

O indivíduo nasceu, enfim. Isto é, tornou-se hegemônico um modo de subjetivação no qual domina uma interioridade natural, dotada de capacidades, desejos, virtualidades, e que é acompanhada de uma necessidade de ser conhecida. Interioridade a ser conhecida por outrem e por nós mesmos. A se conhecer e se transformar, tendo em vista a ampliação de aptidões e a extorsão de suas forças. Por técnicas policiais, médicas, psicológicas, pedagógicas.

Um nascimento acompanhado da necessidade de gerir a vida (FOUCAULT, 1988). Ora, até o século XVII, dominava um poder no qual era lícito expor vidas a qualquer sinal de ameaça ao soberano; um poder que se exercia justamente quando fazia morrer. A vida era o que escapava; deixava-se viver; ela passava a importar quando fosse apreendida, confiscada; afinal, em tempos em que dominam o confisco, a vida também o poderia ser.

Mas o que assistimos com a emergência das disciplinas vai na contramão do confisco da vida. Passa a dominar um poder que visa produzir forças, majorando e ordenando-as. Confiscar vidas passa, então, a ser improdutivo; traz prejuízos, já que forças se perdem, sendo jogadas fora com a morte. Uma mudança substancial:

Pode-se dizer que o velho direito de causar a morte ou deixar viver foi substituído por um poder de causar a vida ou devolver à morte. (...) Agora é sobre a vida e ao longo de todo o seu desenrolar que o poder estabelece seus pontos de fixação; a morte é o limite, o momento que lhe escapa; ela se torna o ponto mais secreto da existência, o mais "privado" (FOUCAULT, 1988, pp.150-151).

A morte torna-se exterior ao poder; escapar da vida - morrer - significa também escapar ao poder. Preocupação com o "como" da vida, em ampliar a vida. Não que a morte 
não fosse mais possível ou justificável; pelo contrário. Pode-se matar, desde que se mate para fazer viver; a morte deve justificar a continuidade de uma população (e não mais a continuidade do soberano). É para isso que, segundo Foucault (1999), intervém o racismo, isto é, um corte entre o que deve viver e o que deve morrer, um corte que determina quem fica e quem sai.

Uma gestão da vida, centrada no corpo-máquina e no corpo-espécie. Uma tecnologia que atravessa a vida de cima a baixo, fazendo com que nenhuma vida escape, ou ao menos tentando fazer. Um biopoder, um poder sobre a vida. Um poder que se dá com o capitalismo, que se entranha com ele. Um poder que controla corpos e lhes extrai as forças e que ajusta os fenômenos de população aos processos econômicos. Um poder que, sobretudo, utiliza técnicas que fazem tudo isso sem tornar a vida mais difícil de sujeitar. Um poder que estatiza o biológico (FOUCAULT, 1999). Um poder ramificado, presente em todo o corpo social, sem necessariamente nos atentarmos para isso. Um poder que tende à invisibilidade, seja nos grandes aparelhos de Estado, seja em instituições e dispositivos diversos - família, escola, polícia, medicina, Igreja, Exército, indústria cultural, ciência. Procedimentos variados e sempre um objetivo: gerir a vida e extrair-lhe o máximo de forças, com o maior lucro possível.

E, como sabemos, um poder que necessariamente é acompanhado de um saber: um saber sobre a vida:

O homem ocidental aprende pouco a pouco o que é ser uma espécie viva num mundo vivo, ter um corpo, condições de existência, probabilidade de vida, saúde individual e coletiva ${ }^{3}$, forças que se podem modificar, e um espaço em que se pode reparti-las de modo ótimo (FOUCAULT, 1999, p.155).

\footnotetext{
${ }^{3}$ E acrescentaríamos as possibilidades de saúde mental, das quais as tecnologias psi vão se ocupar, conforme veremos adiante.
} 
E emergem as ciências de saúde, humanas e sociais. Ciências que se encarregaram da vida e de fazer viver. Da vida individual e coletiva, com seus processos e movimentos. Como efeito desse saber-poder centrado na vida, uma sociedade normalizadora, marcada por mecanismos contínuos de regulação e correção; mecanismos que buscam a vida em todos os lugares; que a buscam para gerir, para governar.

\section{1- Governo e população}

Como vimos, a vida passa a importar. A vida individual e a vida em espécie. No controle dos corpos - nessa vida individualizada - a intenção que domina é expandir a vida, possibilitando maximizar suas forças e o aproveitamento delas. Para isso, antecipação; antecipar-se aos acontecimentos, avaliando suas virtualidades, em uma vigilância constante. Leis não são suficientes; não basta dizer que "não roubarás" ou dizer quais as punições para isso; torna-se necessário antecipar-se e descobrir, antes do ladrão roubar, se ele roubará. E não basta mais punir; cabe corrigi-lo (FOUCAULT, 2008a). Uma certa aposta humanista, que diz, de alguma forma, que os indivíduos guardam em si possibilidades de conversão; uma aposta humanista que inclui as pessoas; que as traz para dentro das relações de poder, mesmo quando elas são supostamente excluídas em prisões, manicômios... Uma aposta humanista que também revela a preocupação com os riscos de uma pessoa reincidir, isto é, sua periculosidade, e a preocupação com os custos dessa reincidência. Uma ideia que se assemelha ao "prevenir é melhor que remediar".

Nesse caminho de antecipação, de prevenção, de controle de perigos, algo se opera; novas questões se colocam. Com a presença cada vez mais marcante da estatística, torna-se possível uma certa tabulação de acontecimentos "individuais". Torna-se possível medi-los; e, uma vez medidos, torna-se possível estimá-los, a partir de expectativas de normalidade. Uma 
operação importante: não se trata simplesmente de prevenir virtualidades, mas de mantê-las dentro de limites que sejam social e economicamente aceitáveis. Tratam-se de mecanismos segurança, uma reativação de técnicas jurídico-legais e disciplinares, como entendido por Foucault (2008a). Uma atenção à população, objeto que emerge no século XVIII.

A população que emerge não é mais simplesmente uma coleção de indivíduos que habitam um território; trata-se de um conjunto de processos; um conjunto que depende de uma série de variáveis, como clima, fenômenos da natureza, legislação vigente, atividades econômicas, hábitos, valores morais e religiosos, desejos, preconceitos. Processos que, de alguma forma, apresentam uma certa constância. Um conjunto de elementos, processuais, que, "de um lado, se inserem no regime geral dos seres vivos e, de outro, apresentam uma superfície de contato para transformações autoritárias, mas refletidas e calculadas" (FOUCAULT, op. cit., p.98.). Algo que vai da espécie - relacionado a processos biológicos, como proliferação, nascimentos, mortalidade, nível de saúde, longevidade - ao público aquilo que age por meio da educação, campanhas, convencimentos. Logo, uma preocupação com os seres humanos enquanto seres vivos e com o seu meio de existência.

Assistimos, então, a coexistência, de técnicas disciplinares - aquelas que destacarão os corpos na multidão - e técnicas de segurança, ligadas a uma biopolítica da população. Como aponta Castro (2009, p.335),

o surgimento da população como objetivo e instrumento do poder não significou o desaparecimento do conceito de soberania nem se contrapõe ao processo de disciplinarização (de caráter individualizante). [...] A ideia de um governo da população fortalece a questão do fundamento da soberania e requer um aprofundamento das disciplinas.

Falamos do biopoder, uma tecnologia de duas faces: "anatômica e biológica, individualizante e especificante, voltada para os desempenhos do corpo e encarando os processos da vida - [que] caracteriza um poder cuja função mais elevada já não é mais matar, 
mas investir sobre a vida, de cima a baixo" (FOUCAULT, 1988, p.152). Quer dizer, o biopoder reúne as disciplinas e a biopolítica. E o que a tecnologia biopolítica faz com as disciplinas é embuti-las, integrá-las, modificá-las (em partes), enfim, faz uso delas tendo em vista os seus objetivos.

Para um novo corpo, o corpo-espécie - “corpo múltiplo, corpo com inúmeras cabeças, se não infinito pelo menos necessariamente numerável” (FOUCAULT, 1999, p.292) - a biopolítica, operando em técnicas de segurança - segurança geral diante dos perigos inerentes à vida - lidará com aquilo que é aleatório, aquilo que não se conhece com exatidão. Em um contexto de crescente urbanização e aumento populacional, muito não se conhece com exatidão; sabem-se que muitos problemas acontecerão, sem possibilidades de serem completamente prevenidos e suprimidos. Doenças, mortes, crimes, aumento de preços, nascimentos... Fenômenos inevitáveis, próprios da vida.

É justamente disso que as técnicas de segurança lidarão: “um futuro não exatamente controlado nem controlável, não exatamente medido nem mensurável” (FOUCAULT, 2008a, p.26). São técnicas que planejam, que levam em conta o que pode acontecer. Técnicas vinculadas ao problema de série, de series abertas, indefinidas. Taxas de natalidade, morbidade, mortalidade, criminalidade; a circulação nas cidades (de pessoas, mercadorias, do ar...); a escassez de alimentos; o aumento de preços. Acontecimentos que se dão em um meio, em um ambiente onde a vida com seus problemas circulam, que deverá ser (re)criado, organizado, planejado por essas técnicas de segurança. A ideia de meio é essencial para essas técnicas, por justamente se relacionar com a ideia de população, isto é, "uma multiplicidade de indivíduos que são e que só existem profunda, essencial, biologicamente ligados à materialidade dentro da qual existem" (FOUCAULT, 2008a, p.28).

Com essa multiplicidade, necessariamente ligada a um meio, lida-se de outra maneira, que parecem ser, de alguma forma, uma derivação de técnicas disciplinares: analisa- 
se o que acontece e programa-se o que deve acontecer. $\mathrm{O}$ adestramento dos corpos - alvo das técnicas disciplinares - torna-se um instrumento, uma condição, para essa gestão do futuro que deve acontecer.

Foucault (2008a) detalha diferenças entre os dispositivos de segurança e os disciplinares. A disciplina se daria essencialmente de forma centrípeta, circunscrevendo espaços e regulamentando tudo, sem deixar escapar nada; decompõe indivíduos, tempos, espaços, atos, operações, tornando tudo visível e transformável, estabelece modelos, de funcionamento ótimo, para depois demarcar o que é normal e anormal, isto é, quem é, respectivamente, capaz ou não de se conformar nessa norma. Vemos, segundo o autor, um processo de normação, marcado por um caráter primitivamente prescritivo da norma.

Já a segurança, centrífuga por princípio, tende a se ampliar continuamente, integrando novos elementos e pondo-os em relação, possibilitando um certo laisse faire, no qual esses elementos vão se ajeitando de alguma forma possível; um certo ar de liberdade, em que as coisas são do jeito que são, se produzem, cabendo aos dispositivos de segurança fazer funcionar em relação a um fenômeno outros elementos do meio, respondendo, dessa forma, "a uma realidade de maneira que essa resposta anule essa realidade a que ela responde - anule, ou limite, ou freie, ou regule" (FOUCAULT, 2008a, p.61). O que está em jogo é a circulação, quer dizer, as possibilidades de deslocamento, trocas, contatos, dispersões, distribuições, e como tudo isso deve ou não acontecer. Nesse controle, várias normalidades são criadas, de acordo com cada situação; normalização que funciona por uma questão de grau, de proximidade diante daquilo que é considerado normal.

Tais diferenças podem ficar mais compreensíveis na comparação entre os modos de se lidar com doenças. O modelo de doença das disciplinas é a peste (FOUCAULT, 1975 [1987]). Em sua gestão, circunscrevem-se espaços, com o fechamento das cidades e sua divisão em quarteirões a serem vigiados por um síndico (que será vigiado por um intendente); 
destacam-se indivíduos, já que todos se trancam em suas casas, onde devem permanecer e serem revistados diariamente pelo síndico, interessado em saber o estado de cada morador. A presença da peste não lhe escapa ao olhar. Registros são feitos permanentemente pelo síndico e intendentes; dados são centralizados e contabilizados. Enfim, um jeito de lidar com a doença que separa, distribui individualmente corpos entre doentes e não-doentes, organiza vigilâncias e controles, buscando prevenir que a peste se alastrasse .

Diante dos dispositivos de segurança, um novo modelo: a varíola, que passa a ser tratada como "caso":

uma maneira de individualizar o fenômeno coletivo da doença, ou de coletivizar, mas no modo da quantificação, do racional e do identificável, de coletivizar os fenômenos, de integrar num campo coletivo os fenômenos individuais" (FOUCAULT, 2008a, p.79).

Mais do que quantificar os casos confirmados, cabe analisar sua distribuição entre indivíduos e grupos, avaliando os riscos de cada grupo em contrair a doença, em morrer, se curar. Avaliando os diferentes riscos vivenciados por diferentes grupos (por exemplo, no século XVIII, o risco para uma criança pegar varíola era da ordem de $2 / 3$, diferente de outras faixas etárias), pode-se identificar onde mora o perigo (por exemplo, é mais perigoso ser criança do que adulto, no que diz respeito à varíola). E, em situações de crise, esses casos podem se multiplicar, podendo serem controlados apenas por intervenções artificiais, que não buscaram simplesmente anular a doença ou prevenir que outras pessoas se contagiem; buscase manter uma média, índices aceitáveis, padronizados. Dessa forma, a atenção não se dará exclusivamente aos doentes, já que não é feita uma divisão entre doente e não-doentes; atentase para toda a população, sem descontinuidade, avaliando-se o coeficiente de morbidade e mortalidade prováveis; quer dizer, avalia-se aquilo que seria o normal em se esperar (para o 
segmento crianças, adulto, mulheres...). Delimitando aquilo que é aceitável, a segurança elimina o efeito da doença.

Nesse sentido, a doença é tratada "não mais como a morte que se abate permanentemente sobre a vida (...) mas como a morte permanente, que se introduz sorrateiramente na vida, a corroi perpetuamente, a diminui e a enfraquece" (FOUCAULT, 1999, p.291).

Importa, assim, medições globais, médias, previsões que se mantenham dentro de uma certa normalidade, aceitabilidade; trata-se de se fixar equilíbrios. Uma vida global, geral, regulamentada. É isso que também será preocupação do governo.

Aliás, a questão do governo se intensifica com o poder sobre a vida. Se a vida começa a importar, importa saber como governá-la, por que métodos, com que fim, por quem deixá-la ser governada. Pergunta feita por indivíduos e populações. Pergunta que vem de todos os $\operatorname{lados}^{4}$.

Foucault (2008a) aponta a emergência até o século XVIII de uma literatura antiMaquiavel, defensora de uma arte de governar, arte esta que pode ser exercida por muitos, já que o governo não diz respeito exclusivamente ao Estado. Considera-se que se governa um Estado, uma casa, um convento, uma família e governam-se almas. Governam, assim, estadistas, pais de família, polícia, religiosos, pedagogos, professores, médicos, psicólogos... Enfim, toda uma pluralidade e imanência das formas de governo.

Ainda, tal literatura considerava a existência de três tipos de governo: o governo de si mesmo, relacionado à moral; a arte de governar uma família, relacionado à economia; e a "ciência de bem governar" o Estado, relacionado à política. Tipos que apresentam uma

${ }^{4}$ Cabe ressaltar que a questão do governo não era uma questão inédita, remontando a um Oriente pré-cristão, no qual se pode observar um poder de tipo pastoral. Trata-se de um poder de tipo religioso, pelo qual Deus e reis eram vistos como o pastor de um rebanho formado por homens. Abordaremos tal questão com a devida atenção no próximo item. 
continuidade entre si, ascendente e descendente, relacionadas, respectivamente, à ideia de que para governar bem o Estado é necessário saber governar a si e a sua família, e à ideia de que, quando um Estado é bem governado, os pais sabem governar a si e a suas famílias.

Vemos aí, a introdução da economia nas preocupações de governo; economia que originariamente designa o "sábio governo da casa para o bem comum de toda a família" (FOUCAULT, 2008a, p.126). Uma preocupação em como se administrar adequadamente os indivíduos, os bens, as riquezas de forma que essa administração alcançasse as bases sociais e ali se exercesse. Inicialmente, é isso que se almeja: que no governo de um Estado se instaurasse um olhar atento como aquele que um pai de família tem sobre sua casa e seus bens. Mas, de modelo de governo, logo a família se torna instrumento para ele. Quer-se governar a população, cujos fenômenos não se reduzem aos da família. A economia será outra: dirá respeito aos processos e fenômenos da população, alvo da estatística, que possibilita medi-los e traçar-lhes as regularidades. O governo de um Estado, assim, tornar-se a busca pelo bem comum, bem da população - com seus desejos, interesses e aspirações; bem que varia de situação para situação e que tende a intensificar os efeitos do próprio governo.

Mas, afinal, o que significa governar? "Governo é a correta disposição das coisas, das quais alguém se encarrega para conduzi-las a um fim adequado" (LA PERRIÈRE 5 , apud FOUCAULT, 2008a, p.127). Governar é um exercício de poder que "consiste em "conduzir condutas" e em ordenar probabilidade. (...) é estruturar o eventual campo de ação dos outros" (FOUCAULT, 1995, p. 244). Conduta que tem a ver com a atividade de conduzir e tem a ver com a maneira como uma pessoa se conduz, se deixa conduzir. Conduzir condutas que se dão em um meio, em um campo de relações; assim, governam-se os indivíduos em suas relações com o meio, consigo mesmo, com os outros, com hábitos, costumes, maneiras de ser e de pensar. E para bem governar, menos imposições, quer dizer, menos leis e mais táticas, que

\footnotetext{
${ }^{5}$ G. De La Perrière, Le miroir politique, f.23r.
} 
possibilitem administrar coletivamente os fenômenos da população e, ao mesmo tempo, administrar a população com sutileza e em cada detalhe.

Uma sociedade que retoma funções do poder pastoral, como aponta Foucault (2008a) e passa a ser marcada por sua governamentalidade. Ou por processos de governamentalização, como preferem chamar Aquino \& Ribeiro (2009), ao assinalarem para seu caráter contínuo e que sempre se refaz. Deixemos que Foucault nos explique do que se trata a governamentalidade:

o conjunto constituído pelas instituições, os procedimentos, análises e reflexões, os cálculos e as táticas que permitem exercer essa forma bem específica, embora muito complexa, de poder que tem por alvo principal a população, por principal forma de saber a economia política e por instrumento técnico essencial os dispositivos de segurança (FOUCAULT, 2008a, p.143).

Quer dizer, a governamentalidade se opera em um campo de forças, consistindo em (re)organizar tais forças, manipulando, mantendo, (re)distribuindo, (re)estabelecendo conexões. Uma articulação entre tecnologias de poder - que produzem condutas, objetivando o sujeito - e tecnologias de si - que fazem com que os indivíduos operem sobre si transformações (FOUCAULT, 2004a). Enfim, práticas objetivas, que visam todo o corpo social, que atingem os indivíduos com seus efeitos subjetivadores.

Almejando a população, a governamentalidade atinge os indivíduos. Ora, como apontamos, administrar a população significa manter seus processos e fenômenos natalidade, mortalidade, criminalidade, etc - em níveis aceitáveis, mas não apenas; significa também administrá-la em seus detalhes, em cada um de seus componentes, isto é, em cada um dos indivíduos. Como aponta Aquino \& Ribeiro (2009, p.61), "trata-se de compatibilizar dois níveis paralelos e complementares de gestão social da vida: o anátomo-político, por meio do 
disciplinamento do corpo-máquina, e o biopolítico, por meio da regulamentação do corpoespécie”.

Do corpo-espécie ao corpo-máquina. Todo o corpo social, de cabo a rabo, se torna alvo do governo. E, como veremos mais adiante, por intermédio de dispositivos dos mais variados.

\section{2- O governo de corpos e populações: $o$ dispositivo de sexualidade}

Para governar a população, o governo dos indivíduos. Uma arte que manipula, mantém, distribui, restabelece relações de forças. Uma certa dispersão de tecnologias disciplinares e a criação de novas maneiras de administrar a multiplicidade, organizando-a; recortando essa multiplicidade e produzindo indivíduos, destacado-os dela. Uma organização de fenômenos da população que, ao mesmo tempo, os organiza e organiza indivíduos de forma a facilitar a gestão desses fenômenos e desses indivíduos, sempre de acordo com efeitos funcionais esperados. Um uso das disciplinas também para o governo da população.

Nesse contexto, Foucault $(1988,1999)$ considera o dispositivo de sexualidade como uma das mais importantes tecnologias biopolíticas. Justamente por constituir o cruzamento mais íntimo entre corpo e população, entre disciplinas e regulamentação; justamente por ser na questão do sexo que o governo da população e dos indivíduos se encontram e, assim, ser uma ocasião privilegiada para o governo de ambos. Ora, o sexo se encontra no cerne do problema político e econômico da população, já que o futuro de uma sociedade também está ligado às maneiras como cada um - e todos nós - usamos o sexo.

Bem, o sexo fala de nosso corpo, com suas funções, processos fisiológicos, anatomia, sensações, prazeres. Ao mesmo tempo, fala de fecundidade e de doenças, acontecimentos que dizem respeito ao presente e ao futuro de uma população. O sexo, assim, 
incide diretamente sobre o indivíduo, falando daquilo que supostamente somos; um indivíduo, para se conhecer, deve conhecer aquilo que diz respeito ao sexo. Ao menos assim nos foi ensinado por um discurso no qual sexo e revelação da verdade estão ligados entre si. Revelar essa verdade, de alguma forma, seria uma condição para nossa felicidade.

Quando falamos de sexo, falamos disso, dessas preocupações. Nesse sentido, longe de se encontrar em territórios de libertação, o sexo é "o elemento mais especulativo, o mais ideal, o mais interior em um dispositivo de sexualidade que o poder organiza em suas capturas dos corpos, sua materialidade, suas forças, suas energias, suas sensações, seus prazeres" (FOUCAULT, 1988, p.169). Quer dizer, é o dispositivo de sexualidade, em suas diferentes estratégias, que faz nascer essa ideia de "sexo". Uma ideia que agrupa elementos anatômicos, funções biológicas, condutas, sensações, prazeres em uma unidade artificial, um significante único, de significado universal. Um ponto fictício por onde devemos necessariamente passar para acessarmos nossa inteligibilidade. Mas sexo é território de gestão da vida, de governo. Corpo, população e alma: coisas a se governar.

Um governo que se faz invisível por essa impressão de que o sexo se refere a algo natural, com todo seu a priori visceral, animal, instintivo. Um governo que busca a invisibilidade também na impressão de que o sexo é território de libertação, sendo o momento em que escaparíamos das garras do poder. Praticando-o ou dele falando. Momentos em que supostamente afrontamos toda uma ordem repressiva, que faz calar desejos tão "naturais"; momentos de suposta transgressão e ousadia.

Invisibilidade operada também na ideia de que o sexo é alvo da tantas repressões. Paradoxal. Devemos descobrir a verdade contida no sexo, ao mesmo tempo em que supostamente ele é alvo de intensas repressões. O que vemos com Foucault, aquilo que chamamos de modo-indivíduo se deu também com a colocação do sexo em discurso e com a produção de um sujeito intensamente sexualizado, incitado, a toda hora, a falar sobre sexo. 
O que se observa a partir do século XVIII é uma explosão discursiva, com o estabelecimento de novas regras de decência e o controle das enunciações, controle que diz quando, onde, em que situações, entre quem, pode-se falar sobre sexo. Quer dizer, fala-se de sexo de outra maneira, outras pessoas falam de sexo, falam com outras pessoas, a partir de outros modos de o ver, com outros objetivos. Cria-se uma situação onde todos querem, mais do que falar, talvez, ouvir sobre o sexo. Uma certa obstinação, vista na intensificação de práticas confessionárias, de exame de si, quer dizer, de um exame minucioso de si.

Uma explosão discursiva que estabelece novas regras:

O sexo, segundo a nova pastoral, não deve mais ser mencionado sem prudência; mas seus aspectos, suas correlações, seus efeitos devem ser seguidos até as mais finas ramificações: uma sombra num devaneio, uma imagem expulsa com demasiada lentidão, uma cumplicidade mal afastada entre a mecânica do corpo e a complacência do espírito: tudo deve ser dito (FOUCAUL, 1988, p.25).

Foucault (2008a) fala de uma nova pastoral, quer dizer, uma tecnologia que aciona, atualiza uma forma de poder pastoral já conhecida, resultando em formas de poder que convivem sem grandes problemas com as disciplinas e a segurança. Na definição de Rose, o poder pastoral seria

uma relação de aconselhamento espiritual entre uma figura de autoridade e cada membro de seu rebanho, corporificando técnicas tais como a confissão e a exposição do eu, a exemplaridade e o discipulado, incorporado à pessoa por meio de uma variedade de esquemas de auto-inspeção, auto-suspeição, exposição do eu, autodeciframento e autoformação (ROSE, 2001, p.38).

O poder pastoral, conhecido desde um oriente pré-cristão - e que emerge no mundo ocidental com o cristianismo, momento em que uma arte passou a ensinar as pessoas a 
governarem os outros e a se deixar governar por alguns ${ }^{6}$ - é um poder que se exerce sobre um rebanho, mais precisamente, exerce-se sobre uma multiplicidade em seu deslocamento. Tratase de um poder benfazejo, que busca ser capaz de triunfar sobre os inimigos e levar o rebanho à salvação, conduzindo-os ou criando condições para que a alcancem. Um poder de cuidado, como observa Foucault (2008a). Um poder que "se manifesta inicialmente por seu zelo, sua dedicação, sua aplicação infinita" (p.171). Afinal, o pastor é aquele que cuida de pormenores, que se ocupa de coisas "banais" como a alimentação de seu rebanho e de cada um dos animais de seu rebanho. Zelar; é isto que o pastor faz. "No sentido de vigilância do que pode ser feito de errado, mas principalmente como vigilância a propósito de tudo o que pode acontecer de nefasto" (p.171). Zelar significa também fazer com que todos - e cada um - se submeta à lei, à vontade de Deus. Zelar significa ainda ensinar a verdade e fazer com que nela acreditem. Zelar pelos outros. Zelar por cada um.

Nesse sentido, o poder pastoral é um poder individualizante. Se o pastor zela a totalidade de seu rebanho, zela também por cada um de seus animais Cada um é merecedor de sua atenção e preocupação. Um poder que também destaca indivíduos de uma multiplicidade, que a organiza, que a particulariza. Um modo de individualização que afirma o eu e implica sua destruição, já que o que vale é a plena obediência ao pastor, independentemente do quão razoável seja a ordem dada e mortificando vontades. O rebanho deve deixar de ter vontades; quer dizer, a única vontade possível é a vontade de não ter vontade. Uma individualização por sujeição.

\footnotetext{
${ }^{6}$ Foucault (2008a) aponta que, com a Igreja cristã, o pastorado se torna autônomo, já que a relação dos homens com Deus será fundamentalmente pastoral: Deus se torna unicamente o pastor dos homens. Ainda, essa relação se institucionaliza em uma forma de poder com regras, técnicas e procedimentos específicos, com toda uma hierarquia de pastores (Cristo, apóstolos, bispos, abades). Torna-se, com a Igreja, "uma arte de conduzir, de dirigir, de levar, de guiar, de controlar, de manipular os homens, uma arte de segui-los e empurrá-los passo a passo" (p.218-219). Poder que permanece diferenciado do poder político até pelo menos o século XVIII, momento da emergência do Estado moderno, que traz em bojo o pastorado e a necessidade de uma prática política calculada e refletida, que governe os homens.
} 
Um paradoxo: a salvação de uma só ovelha deve ser alvo da atenção e preocupação do pastor com todo o rebanho. Ao mesmo tempo, a salvação de todo o rebanho deve se dar, mesmo que seja necessário o sacrifício da ovelha que possa vir a comprometer o todo. Preocupação, então, com virtualidades.

Um poder que zela também pelas almas dos indivíduos, na medida em que "essa condução das almas também implica uma intervenção, e uma intervenção permanente na conduta cotidiana, na gestão das vidas, mas também nos bens, nas riquezas, nas coisas" (FOUCAULT, 2008a, p.204). Uma intervenção integral, a cada instante, que busca atingir a conduta total, integral. Uma intervenção que busca a direção da consciência, direção permanente, a propósito de tudo e por toda a vida. Exame da consciência, sobretudo por práticas de confissão, que se tornam obrigatórias na Igreja cristã a partir do século XI. Subjetivação em curso; verdades internas, secretas a serem descobertas.

$\mathrm{Na}$ atualização do poder pastoral, o sexo se torna objeto de interesse público, de zelo de uma série de pessoas: médicos, pedagogos, religiosos... Sobre ele passa a operar um duplo exame: do corpo/carne - origem dos pecados - e do desejo, com suas inquietações. O que se faz é tornar também o desejo um discurso. Exame da junção do corpo com a alma: "ele [o discurso] revela, sob a superfície dos pecados, a nervura ininterrupta da carne" (FOUCAULT, 1988, p.26). Assistimos, ao longo do século XVIII a emergência de uma incitação política, econômica, técnica a falar do sexo, sob a forma de análise, contabilidade, classificação, especificação, com a realização de pesquisas quantitativas ou causais. Objetiva-se superar o "moralismo" e as barreiras que impediam que se tocasse no assunto:

deve-se falar do sexo, e falar publicamente, de uma maneira que não seja ordenada em função da demarcação entre o lícito e o ilícito, mesmo se o locutor preservar para si a distinção [...]; cumpre falar do sexo como de uma coisa que não se deve simplesmente condenar ou tolerar mas gerir $^{7}$, inserir em sistemas de utilidade, regular para o bem

\footnotetext{
${ }^{7}$ Grifo nosso.
} 
de rodos, fazer funcionar segundo um padrão ótimo. O sexo não se julga apenas, administra-se. Sobreleva-se ao poder público; exige procedimentos de gestão; deve ser assumido por discursos analíticos. No século XVIII o sexo se torna questão de "polícia", (FOUCAULT, 1988, pp.30-31).

Em busca da verdade ou da purificação, a confissão deve ser constante. Uma confissão para o outro e para si. Confissão de tudo aquilo que tenha certa afinidade com o sexo.

Essa vigilância constante relaciona-se com a pastoral cristã, que tornou, já há muitos séculos, uma tarefa fazer passar tudo aquilo que se relaciona com o sexo pelo crivo interminável da palavra. Uma maneira de tornar o que era dito moralmente aceitável e tecnicamente útil. Nessa tarefa, investiga-se aquilo que o indivíduo fez em detalhes, nada deve escapar, mas isso não é tudo; percebe-se já uma preocupação com as virtualidades do desejo. Quer dizer, em última instância, não importam os atos; importam as possibilidades de vir a fazer. Incidindo sobre virtualidades, cabe uma certa reorientação do desejo; uma condução do desejo; o governo do desejo.

Este será o princípio que regerá a gestão do sexo. Uma gestão não meramente repressiva, mas uma gestão que busca ordenar e majorar as forças coletivas e individuais, através do reordenamento do desejo. Reordenamento disperso, operado em diversos mecanismos. Cria-se uma sensação de falta permanente: de que nunca falamos ou sabemos o

\footnotetext{
${ }^{8}$ Diferentemente do aquilo que conhecemos atualmente, a polícia era responsável, nos séculos XVII e XVIII, pela garantia do esplendor do Estado e da felicidade dos súditos, tratando-se de um conjunto de meios pelos quais o Estado poderia ter suas forças aumentadas; quer dizer, aquilo que o mantém e intensifica, maximiza. Diz Foucault (2008a): "a polícia dever assegurar-se de que os homens vivam, e vivam em grande número, (...) deve assegurar-se de que ele tenham de que viver e, por conseguinte, tenham de que não morrer muito, ou não morrer em quantidade grande demais" (p.438). Cuida da vida, da circulação, é o "exercício soberano do poder real sobre os indivíduos que são seus súditos (...) é a governamentalidade direta do soberano como soberano" (p.457). Nesse sentido, para intensificar as forças do Estado importa - e muito - cuidar de miudezas e detalhes, importa gerir o sexo.
} 
suficiente sobre o sexo. Uma certa dispersão do sexo, do falar de sexo. Uma incitação, regulada e polimorfa. Um discurso que se ramifica, pela medicina, psiquiatria, justiça penal. Vemos isso na histerização do corpo da mulher, corpo este que se investe de sexualidade; na pedagogização do sexo das crianças, cujas atividades potencialmente perigosas - como a masturbação - passam a ser alvo de atenção; na socialização das condutas procriadoras, com um planejamento que visa aumentar ou diminuir a fecundidade das pessoas. Vemos isso também no aumento de condenações judiciárias de perversões; na conexão de irregularidades sexuais a doenças mentais; na definição de normas do desenvolvimento sexual da infância à velhice; na constituição de tratamentos médicos; enfim, na multiplicação de "perversões".

Foucault (1988) destaca a importância das perversões nesse processo. Instaurá-las permitiu que o poder se ramificasse. Patologias foram inventadas, com a implantação de todo um regime médico-sexual. Novas formas de aproximação, novos exames, novas confissões. Uma "proliferação de sexualidades por extensão do poder; majoração do poder ao qual cada uma dessas sexualidades regionais dá um campo de intervenção” (p.56).

Novos controles sociais operam, filtrando "a sexualidade dos casais, dos pais e dos filhos, dos adolescentes perigosos e em perigo - tratando de proteger, separar e prevenir, assinalando diagnósticos, acumulando relatórios, organizando terapêuticas" (FOUCAULT, 1988, p.37).

Como ressalta Castro (2009), em todas essas estratégias, a questão não é simplesmente inibir ou ocultar a sexualidade; trata-se de incitá-la e produzi-la. Uma incitação ortopédica. Uma gestão que torne o sexo útil. E se falamos na criação de utilidades, nada mais providencial do que uma atenção para aquilo que costumeiramente escapa: as sexualidades periféricas.

Será a partir delas que se definirá a sexualidade regular, através de um movimento de refluxo. Cabe saber como é a sexualidade de crianças, dos loucos, dos criminoso, de 
pederastas, dos acometidos por um estranho "vício". Enfim, dos loucos morais, dos degenerescentes, dos desequilibrados. Uma ideia que, a princípio, pode parecer estranha, que nos faz pensar na relação normal-anormal.

É sobre a sexualidade dos anormais que se constitui a sexualidade normal. Nas palavras de Canguilhem (2009, p.205), “o anormal, que logicamente é o segundo, é existencialmente o primeiro". Quer dizer, aquilo que atrapalha, que incomoda é o ponto de partida em uma sociedade excludente como a que conhecemos. A criança que se masturba, o homossexual, os que transam de forma pouco usual; é a partir deles que se vai determinar qual a sexualidade adequada. Falamos de uma intenção normativa em jogo, de uma exigência de racionalização que se opera pela normalização.

Uma certa empiria da vida que torna necessária a previsibilidade. E, mais uma vez, falamos das virtualidades. É preciso prever acontecimentos da vida, buscando a sua máxima exploração. O normal, assim, diz respeito, de um modo geral, àquilo que possibilita um maior aproveitamento de forças. O normal não apenas indica qual norma/regra seguir, ele multiplica a regra, ele é sua extensão. É isso que faz uma sociedade normalizadora: impõe regras, exigências a existências, existências que são múltiplas, díspares, o que é entendido com hostilidade, com uma necessidade em ser alterado, unificado, superado em sua diferença. Quer dizer, normalizado. Normalizar assume um caráter de substituição daquilo que é insatisfatório por aquilo que é satisfatório. Normalizar é valorar, julgar, discernir o que é infração e precisa ser corrigido. E é justamente a infração que possibilita que uma regra se torne uma regra; é a infração que regula a norma e não o contrário, como muitas vezes podemos pensar.

Rose (2001) é enfático quanto a esta questão:

Nossos vocabulários e nossas técnicas da pessoa não surgiram, em geral, em um campo de reflexão sobre o indivíduo normal, o caráter normal, a personalidade normal, a inteligência normal, mas, em vez 
disso, a própria noção de normalidade surgiu de uma preocupação com tipos de conduta, pensamento e expressão considerados problemáticos ou perigosos (p.37).

Essa atenção - ou "caça", nas palavras de Foucault (2008a) - às sexualidades periféricas possibilita uma nova especificação dos indivíduos. Quer dizer, subjetivam-se essas pessoas, dando-lhes uma certa natureza singular, uma individualidade: uma história de vida, um caráter, uma anatomia. Novos indivíduos são inventados, especificados, categorizados, de acordo com suas sexualidades.

Com o poder, um saber. O que se observa é uma construção do sexo enquanto objeto de verdade, com o desenvolvimento de uma scientia sexualis, marcada por técnicas confessionárias que se apresentam amplamente, na justiça, medicina, pedagogia, relações familiares, amorosas, cotidianas, a ponto de Foucault (1988, p.68) considerar que "o homem, no Ocidente, tornou-se um animal confidente". Deixemos que o autor nos diga, por suas próprias palavras, de que se trata a confissão:

a confissão é um ritual de discurso onde o sujeito que fala coincide com o sujeito do enunciado; é, também, um ritual que se desenrola numa relação de poder, pois não se confessa sem a presença ao menos virtual de um parceiro, que não é simplesmente o interlocutor, mas a instancia que requer a confissão, impõe-na, avalia-a e intervém para julgar, punir, perdoar, consolar, reconciliar; um ritual onde a verdade é autenticada pelos obstáculos e as resistências que teve de suprimir para poder manifestar-se; enfim, um ritual onde a enunciação em si, independentemente de suas conseqüências externas, produz em quem a articula modificações intrínsecas: inocenta-o, resgata-o, purifica-o, livra-o de suas faltas, libera-o promete-lhe a salvação (FOUCAULT, 1988, pp.70-71).

Uma técnica que nos faz falar de nós mesmos; quer dizer, que instaura um "si mesmo" em nós, um a priori. Um "si mesmo" que tem de ser cada vez mais superado, alcançado, caso queiramos descobrir nossas verdades mais secretas, de forma a nos garantir a liberdade, a felicidade e talvez a salvação. 
Técnica que busca, no fundo de si, de cada um, verdades. Descobrir-nos torna-se uma tarefa usual, "invisível”, que "já está tão incorporada a nós que não a percebemos mais como efeito de um poder que nos coage" (pp. 68-69). Tarefa tão incorporada que, quando não a fazemos, atribuímos esse não fazer a uma violência do poder, que nos impede de conhecermos quem realmente somos. Nesse sentido, ao contrário de uma sensação de estarmos sendo alvo do poder, é comum que entendamos que a confissão libera, nos liberta das artimanhas do poder. Falar do sexo, de nossos segredos individuais, assim, seria um exercício de liberdade. Engano: nada mais do que o poder em nós.

Confessar quem somos, não simplesmente o que fizemos. Quer dizer, reconstituir "os pensamentos e as obsessões que o acompanham [o ato sexual], as imagens, os desejos, as modulações e a qualidade do prazer que o contém" (FOUCAULT, 1988, p.72).

Uma confissão que se entrelaça à ciência, a uma ciência-confissão, que dela necessita, que opera justamente a partir do jogo inconfessável-confesso. Uma ciência que, para extorquir verdades, combina a confissão com o exame, isto é, uma "narração de si mesmo com o desenrolar de um conjunto de sinais e sintomas decifráveis" (FOUCAULT, 1988, p.74). Um fazer clínico do fazer falar. É necessário que se fale e examine tudo, já que o sexo possui um poder causal sem fim e polimorfo; quer dizer, o sexo é um perigo iminente, um perigo de qualquer coisa. E poder causar sorrateiramente, já que ele se esconde. Ainda, não basta extorquir a verdade como se ela estivesse ali, pronta, no sujeito; ela está ali, mas desconhecida de si; cabe àquele que examina dizer a verdade dessa verdade obscura. Experts capazes de examinar e decifrar, pois examinar significa também decifrar. Decifrar que se insere em uma lógica medicalizante, passível de intervenções, de operações terapêuticas. O sexo não diz respeito apenas a culpas e pecados; diz respeito, sobretudo, ao regime do normal e do patológico. Uma ideia de que "a verdade cura quando dita a tempo, quando dita a quem é devido e por quem é, ao mesmo tempo, seu detentor e responsável” (p.77) vai legitimar o uso 
da confissão entre o meio médico - e psicológico - que busca ajustamentos. Que busca a produção de sujeitos ensimesmados devidamente ajustados, produtivos.

Rose $(1998,2001)$ aponta que na sociedade moderna, o individuo é constituído como um "eu", uma entidade naturalmente singular e distinta, altamente subjetivada. Um fenômeno permanente, estável, que atravessa o tempo e contextos distintos. Indivíduos entendidos como seres psicológicos, que se interrogam em termos de uma vida psicológica interior, vida esta que guarda os segredos de sua existência e de sua autenticidade. Vida esta que deve ser descoberta, por nós e por uma série de experts da subjetividade, os "engenheiros da alma humana".

Engenheiros que se ocupam em estimular a subjetividade, difundindo sua autoinspeção e autoconsciência, produzindo desejos. Busca-se maximizar capacidades, de forma a aumentar sua eficácia e suas possibilidades de aproveitamento. Engenharia da alma que cria linguagens e aciona novas realidades, novas maneiras de lidarmos conosco, novas maneiras de nos governarmos.

Mas “o eu não constitui o objeto trans-histórico das técnicas para se tornar humano, sendo, em vez disso, apenas uma das formas por meio das quais os seres humanos foram convocados a compreenderem a si mesmos e a se relacionarem consigo mesmos", diz Rose (2001, p.42).

Seguindo o exercício foucaultiano, o autor se propõe a fazer a genealogia das relações dos indivíduos consigo mesmos. Isto é, as práticas nas quais eles se relacionam consigo mesmos, na perspectiva do governo, o que nos faz pensar que essas formas pelas quais nos compreendemos e vivemos nossa existência enquanto sujeitos são moldadas por práticas sociais e produzem experiência. E são essas práticas que vão instaurar aquilo que conhecemos como individualidade, caráter, personalidade, enfim, um “eu”. Falamos de um

\footnotetext{
${ }^{9}$ No original, "self”, o que aponta para um eu reflexivo, um "si”.
} 
regime de subjetivação no qual o desejo "foi transformado em uma variedade de paixões voltadas para a descoberta e a realização do próprio eu” (IBID, p.42). Mentalidades e corporeidades são fabricadas. E as maneiras pelas quais os indivíduos aprendem a se relacionar consigo mesmos são deveras importantes em um contexto em que condutas devem ser conduzidas.

\section{3- Um governo que se prolifera}

Tecnologias do eu. Entranhadas nessa massiva busca por indivíduos livres, autônomos, desejantes (que desejam e conhecem seus desejos), capazes de escolher, indivíduo característico de um mundo onde o liberalismo e o capitalismo mundial integrado dominam, em um mundo onde são hegemônicos os modos de produção capitalísticos (GUATTARI \& ROLNIK, 2005).

Que vivemos em um mundo em que domina o capitalismo, não nos resta dúvida. Mas os autores vão além: ao empregarem o termo capitalístico, designam não apenas as ditas sociedades capitalistas, como também todas aquelas nas quais se domina o mesmo modo de produção de subjetividade e da relação com o outro, independentemente de seus modos de produção econômica.

Nesse sentido, aquilo que conhecemos enquanto socialismo também se encontraria nesse modo de produção, por não conseguir romper com os modos de subjetivação do mundo capitalista. Sujeitos, indivíduos, ou quer seja a denominação utilizada, permanecem. Uma certa forma-homem, o modo-indivíduo, persiste. Dessa forma, o modo de produção capitalístico é determinado por uma dupla sujeição: não apenas a sujeição econômica, como, sobretudo, a sujeição subjetiva. Pilares do Capitalismo Mundial Integrado, o capital se ocupa 
da mais-valia econômica e, de modo complementar, a cultura se ocupa da mais-valia da subjetividade.

A subjetividade, dessa forma, se torna um negócio de Estado, uma questão a se governar. Um recurso na administração dos problemas da nação (ROSE, 1998). Daí a necessidade em se confessar: produzir dados a serem gerenciados. A subjetividade, assim, é algo que faz parte de cálculos de um governo que integra técnicas disciplinares, pastorais e de segurança. Um panoptismo que se opera cada vez mais em nós, em uma vigilância contínua, invisível, entranhada em práticas confessionárias e exames de nossa consciência permanentes. Tudo em nome da salvação de nosso destino. Do nosso e de nosso rebanho, isto é, da população. E não podemos nos esquecer das técnicas de soberania, haja visto a defesa - quase sempre incondicional - de um aparato legalista que atravesse da forma mais plena possível todo o corpo social e transforme todos os indivíduos em cidadãos, dotados de direitos e deveres.

$\mathrm{Na}$ busca em aprimorar essas formas de sujeição, acompanhamos verdadeiras mutações do capitalismo. Mutações que possibilitem sua atualização contínua, constante e, com isso, sua expansão. Se, por exemplo, no século XIX falávamos em concentração, produção e propriedade, hoje falamos de um capitalismo voltado para a sobre-produção, que “não compra mais matéria-prima e já não vende produtos acabados: compra produtos acabados, ou monta peças destacadas. O que ele quer vender são serviços, e o que ele quer comprar são ações” (DELEUZE, 1992, p.223). Um caráter dispersivo que possibilita que instituições como família, escola, fábrica - e arte - tenham uma intensa capacidade de se transformar, deixando de ocupar espaços fechados, com a implementação progressiva, dispersa, diluída de novos regimes de dominação. Sociedade de controle, chama o autor; uma sociedade que coincide com aquilo que Foucault (2008a) chamou de sociedade de segurança, na qual domina a governamentalidade. 
A regra é simples: o que importa é maximizar lucros, sejam eles econômicos, sejam subjetivos. Aliás, subjetividade e economia são cada vez mais aproximados, já que a primeira tem uma importante função diante da segunda: certas subjetividades são economicamente mais produtivas que outras e mesmo as que não são tão produtivas ainda guardam possibilidades de produção. Ainda, a subjetividade deve ser gerenciada da mesma forma que se gerencia uma empresa; cada vez mais, a economia vem se prestando como princípio de inteligibilidade da subjetividade e das relações sociais, conforme Foucault (2008b).

Uma forma de aumentar sua possibilidade de expansão - e, assim, os lucros - tem a ver com as possibilidades de superar as críticas que lhe são feitas. Ao invés de aniquilá-las, o capitalismo se mostra capaz de incorporá-las em seu funcionamento. Assim ele vem se portando. Se a morte é dispendiosa, valoriza-se a vida; se o controle de indivíduos é necessário, mas insuficiente, controlam-se populações; se o corpo não basta, governa-se a alma. Formas que sempre procuram incluir, mesmo aquilo que, a princípio, vá na contramão de sua afirmação enquanto sistema dominante. As críticas formuladas nos anos 1960-70, por exemplo, serviram para que se forjasse um novo espírito do capitalismo. Ao se referir à obra Le nouvel esprit du capitalisme, de Boltanski e Chiapello, Pelbart (2003, p.96) diz que, em linhas gerais,

as reivindicações por mais autonomia, autenticidade, criatividade, liberdade, até mesmo a crítica à rigidez da hierarquia, da burocracia, da alienação nas relações e no trabalho, foi inteiramente incorporada pelo sistema, e faz parte de uma nova normatividade que está presente nos manuais de management que seus executivos seguem hoje.

Esse novo capitalismo, além de incorporar tais críticas em seu funcionamento, tem assumido um novo caráter: a busca incessante por novas possibilidades de conexão. Conexões com tudo, com todos e em qualquer situação, desde que elas sejam úteis (ou criem novas utilidades), que favoreçam hibridismos, interfaces, migrações, metamorfoses, ampliando 
horizontes. Possibilidades de conexões que se serpenteiam por aí. Um capitalismo em rede, um capitalismo conexionista, um capitalismo cada vez mais rizomático (PELBART, 2003).

Nesse contexto, processos de normalização cada vez mais marcados por mobilidade, flexibilidade, tendo em vista sempre a criação de previsibilidades mais precisas - ou que tenham um maior alcance, em uma espécie de varredura pelo campo social - e, assim, a contenção de riscos. Para isso, ampliando suas possibilidades de conexão, com mais e mais práticas, de forma a enquadrar cada vez mais e tornar o máximo de pessoas produtivas ao máximo. Normas que operam modulações, alcançando todos - ou, ao menos, pretendendo alcançar. Uma normalização que traz para dentro, que inclui o "anormal”, já que, dividindo entre normal e anormal, perde-se potência. Uma normalização que se serpenteia, produzindo flexibilidades, produzindo referenciais cada vez mais enlouquecidamente móveis, com intensas faixas de tolerância. Tolerância que visa atingir a produtividade virtual dos sujeitos. Criação de variados "desde que", que permitem uma existência, desde que regulada por uma nova norma. Enfim, uma normalização que cria potenciais de utilidade a serem capitalizados. Mesmo que esses potenciais se encontrem em corpos que tenham de ser tolerados.

Talvez essa seja a lógica do capitalismo: expandir-se. Custe o que custar. Quer dizer, custe menos e alcance mais e de forma mais eficaz. Uma expansão que busca, necessariamente, a (re)produção do modo-indivíduo, desse "eu” individualizado, sexualizado e psicologizado. Um capitalismo, então, que se expande, se entranha em nossa vida cotidiana. E traz consigo tecnologias do eu que também se ramificam e se dão cotidianamente, sem que necessariamente percebamos.

Uma das maneiras de se proliferarem diz respeito, aponta Rose (1998, 2001), a proliferação de expertises, ligadas ao desenvolvimento de disciplinas "psi”, bem intencionadas na promoção de felicidade e potentes técnicas de governamentalidade, já que tornam a individualidade visível e possibilitam que suas forças sejam transformadas em bases 
calculáveis. Potência que tem a ver com a variedade de modelos de eu oferecidos, variedade de receitas de como conduzir condutas de si e dos outros, variedade de público atingido. Potência que tem a ver com suas pretensões em revelar a verdade sobre nossa existência. Potência de uma linguagem acessível, capaz de seduzir e atrair muitas atenções, além de possibilitar uma aplicabilidade social que tende à generalização. Enfim, uma potência normalizadora, que calibra o devido indivíduo - o indivíduo normal - para uma dada população.

Práticas culturais, nesse contexto, também podem ser atravessadas por técnicas do eu, por técnicas que calibrem a psique humana, delimitando normalidades e patologias, ao mesmo tempo em que fazem com que indivíduos se relacionem consigo mesmos de forma psicologizada, sexualizada, unificada. Afinal, conhecer a si mesmo tornou-se uma tarefa cotidiana, quase que compulsória. Um trabalho de si sobre si. Um trabalho avaliativo, a partir de critérios fornecidos por outrem. E talvez em qualquer coisa que façamos, em um filme qualquer que assistamos, sejamos presas fáceis desses processos de governamentalização. 
PARTE IiI- CÂMERA 


\section{UMA EXTREMIDADE: O CINEMA}

Quando as luzes se apagam, algo acontece. Na condição de espectadores, algo acontece conosco. Das antigas salas com o cheiro envelhecido - do couro de suas cadeiras e do carpete tão pisoteado - e com ares kitsch na descombinação de suas cores às mais modernas salas, com cadeiras reclináveis em tantas posições, aspecto esterilizado das poltronas e carpetes, que sempre parecem novos. Das salas em grandes shoppings onde se comem combos hipercalóricos às salas onde pipoca é proibida. Das sessões no cinema, às sessões em casa, seja em filmes exibidos pelas emissoras de TV, seja naqueles reproduzidos em DVD. Algo acontece.

Ao assistir um filme, parece que adentramos um mundo outro, seja pelas condições de exibição, seja pelos sistemas de som, pelas dimensões da tela, pelo ambiente escurecido. De alguma forma, parece habitarmos a narrativa apresentada. E as tentativas em se quebrar as barreiras entre espectador e narrativa são intensas. Se anos atrás, as técnicas de som nos surpreendiam ao espalharem sons por todos os cantos da sala, hoje assistimos a proliferação de filmes com tecnologia $3 D$ : com o uso de um simples par de óculos, um filme deixa de habitar apenas a tela, espalhando-se entre nós.

Nesse contexto, de que maneiras o cinema poderia nos ajudar a pensar processos de governamentalização que dizem respeito a discursos de aceitação das diferenças sexuais? Partimos da idéia de que o cinema é atravessado por algo da ordem educativa, no sentido de criar um campo de afetação e produzir modos de ser, de pensar, de sentir, enfim, produzir modos de subjetivação. Investigar como o cinema se constitui nessa poderosa máquina de produção semiótica e subjetiva nos parece um caminho para pensarmos seu caráter educacional. Para isso, pensar seu caráter formal, isto é, técnico, será de grande importância para entendermos os efeitos de uma técnica, marcada pela possibilidade de reprodução 
contínua, nos modos de subjetivação contemporâneos. Temos pela frente, assim, o desafio de entender como se dão as relações entre cinema, educação e modos de subjetivação.

A relação estabelecida entre cinema e espectador não é uma relação qualquer. Um jogo de forças. Onde verdades interpelam o espectador, que, por sua vez, opera também possibilidades para a trama, atribuindo-lhe sentidos. Verdades poderão ser (re)inventadas, confirmadas, refeitas, recusadas. O mesmo com realidades. E com valores, sensações, modos de pensar, de ser, de estar no mundo.

Nesse contexto, podemos pensar o cinema para além de uma prática de entretenimento ou uma nova arte. O cinema parece falar de uma reorganização de um campo - artístico, econômico, cultural...; algo que traz consigo transformações intensas, de tal forma que Benjamin (1936 [1994]), ao discutir as mudanças trazidas pela reprodução contínua das obras de arte, afirma que o cinema corresponderia a metamorfoses profundas do aparelho perceptivo do homem contemporâneo. Tudo isso nos faz pensar o cinema como um dispositivo.

Em entrevista realizada em 1977, época do lançamento do primeiro volume de História da Sexualidade, Foucault (1979) ${ }^{10}$ procura definir aquilo que chamou de dispositivo. Trata-se de:

um conjunto decididamente heterogêneo que engloba discursos, instituições, organizações arquitetônicas, decisões regulamentares, leis, medidas administrativas, enunciados científicos, proposições filosóficas, morais e filantrópicas Em suma, o dito como o não dito são os elementos do dispositivo. O dispositivo é a rede que pode se estabelecer entre estes elementos (p.244).

${ }^{10}$ A versão original da entrevista encontra-se em FOUCAULT (2001), também aqui utilizada. 
Foucault enfatiza que o dispositivo é justamente a natureza da ligação, do nexo que pode ser estabelecido entre esses elementos heterogêneos, uma ligação que configura um campo onde se passa um jogo, mudanças de posição, modificações de funções desses elementos. Um tipo de formação que em um dado momento histórico responde a uma urgência - esta é a principal função e natureza do dispositivo, quer dizer, uma função estratégica.

Uma certa manipulação, configuração de relação de forças; uma intervenção racional diante dessas relações de forças, desenvolvendo-as em determinada direção, bloqueando-as, estabilizando-as; quer dizer, uma intervenção que produz efeitos. Inscrito em um jogo de poder - e, como tal, ligado aos limites do saber - o dispositivo, segundo Foucault (1979) é o lugar de um duplo processo:

por um lado, processo de sobredeterminação funcional, pois cada efeito, positivo ou negativo, desejado ou não, estabelece uma relação de ressonância ou de contradição com os outros, e exige uma rearticulação, um reajustamento dos elementos heterogêneos que surgem dispersamente; por outro lado, processo de perpetuo preenchimento estratégico (p.245).

Agamben (2009) avalia que este é um conceito operativo de caráter geral, definido como "qualquer coisa que tenha de algum modo a capacidade de capturar, orientar, determinar, interceptar, modelar, controlar e assegurar os gestos, as condutas, as opiniões e os discursos dos seres viventes" (p.40). Assim, um conjunto de práticas e mecanismos heterogêneos, inseridos em um campo de forças, em relações de poder - que buscam fazer frente a uma urgência, uma questão prática, concreta, produzindo um efeito sobre ela.

Dispositivo se refere àquilo "que e por meio do qual se realiza uma pura atividade de governo sem nenhum fundamento no ser" (p.38). Faz referência a uma oikonomia: "um 
conjunto de práxis, de saberes, de medidas, de instituições cujo objetivo é gerir, governar, controlar e orientar, num sentido que se supõe útil, os gestos e os pensamentos dos homens" (AGAMBEN, 2009, p.39).

Uma "montagem", nas palavras de Barros (1994), que ressalta que pensar o dispositivo é pensar efeitos - sobretudo, subjetivos. Serão eles que possibilitarão ou não sua permanência e, como apontou Foucault (1979), o dispositivo apresenta certa mobilidade, mobilidade englobadora, marcada por um processo de preenchimento estratégico, de inclusão de novos efeitos - não previstos - dentro de suas estratégias.

Nesse sentido, pensar o dispositivo implica necessariamente pensarmos o processo de subjetivação acionado por ele; quer dizer, o dispositivo é uma máquina que produz o seu sujeito; uma máquina de governo, uma máquina que conduz condutas. Seu efeito, assim, é a condução de condutas.

O cinema, pensado nessa perspectiva - enquanto um dispositivo - é uma máquina cultural que aciona certos modos de subjetivação. Em um contexto marcado pela reprodutibilidade das obras de arte - característica de um modo industrial de se fazer arte -, cabe-nos pensar os efeitos produzidos por ele.

\subsection{Um dispositivo da (na) indústria cultural}

Foucault, em suas análises, fornece ferramentas de grande potência para diagnosticarmos o tempo presente. Maia (2005), ao traçar aproximações entre o pensamento foucaultiano e o de pensadores da primeira geração da Escola de Frankfurt, sobretudo Adorno e Horkheimer, aponta uma grande semelhança entre as críticas à modernidade realizadas por esses três autores. O projeto genealógico foucaultiano, nesse sentido, é considerado uma 
radicalização da crítica realizada por Adorno e Horkheimer, em Dialética do esclarecimento (1985).

Destacamos, dentre as aproximações traçadas, o fato de ambos autores reconhecerem "um formidável crescimento dos mecanismos utilizados para o controle e a submissão dos sujeitos" (MAIA, 2005, p.71), situados nas disciplinas e no biopoder de Foucault e na "sociedade administrada" dos frankfurtianos. Um crescimento que se dá dentro de uma racionalidade social que implica violências ao corpo e que, de uma maneira geral, dá-se na otimização do cálculo de custo-benefício.

Nesse contexto, parece-nos que Adorno \& Horkheimer (1985) trazem grandes contribuições em suas percepções a respeito das mudanças trazidas com novas práticas culturais, que emergem com a chamada indústria cultural. Procuraremos, assim, trazer à tona alguns dos efeitos percebidos por eles a respeito de práticas artísticas contemporâneas.

Os autores consideram que a cultura contemporânea confere a tudo um ar de semelhança, havendo uma continuidade e coerência entre diversas práticas artísticas cinema, rádio, revistas - e uma continuidade entre as práticas artísticas e outras práticas sociais. Para eles, a técnica da indústria cultural levou à padronização e à produção em série, exercendo uma função econômica e buscando o controle da consciência individual. Controle que se dá com ares de liberdade, que perpetuam a ideia de que os indivíduos são independentes, com possibilidades de escolha, em acasos que dificilmente escapam do planejamento. Controle vago, descompromissado, mas nem por isso menos eficaz.

A indústria cultural, conforme definido por Hullot-Kentor (2008), refere-se à produção de cultura por meio da indústria; algo que também produz barbárie, já que se liga a um meio de produção que se reduz à luta pela sobrevivência, não possibilitando a expansão das possibilidades de vida. Quer dizer, uma produção marcada por uma reprodução contínua, de longo alcance, que visa a manutenção do status quo. Para isso, 
a unidade implacável da indústria cultural atesta a unidade em formação da política. As distinções enfáticas que se fazem entre os filmes das categorias A e B, ou entre histórias publicadas em revistas de diferentes preços, têm menos a ver com seu conteúdo do que com sua utilidade para a classificação, organização e computação estatística dos consumidores. Para todos algo está previsto: para que ninguém escape, as distinções são acentuadas e difundidas (ADORNO \& HORKHEIMER, 1985, p.101).

Observando que os produtos da indústria cultural atravessam todo o corpo social, não dando folga a ninguém, os autores frankfurtianos parecem vislumbrar efeitos de governamentalidade. Ora, o que a indústria cultural faz é destacar indivíduos de uma multiplicidade, categorizando-os de acordo com os produtos a serem consumidos e produzindo comportamentos, atitudes, enfim, conduzindo suas condutas. Ao mesmo tempo, governa o todo, organizando a população consumidora em grupos estatísticos, gerenciando dados, taxas de interesse e de consumo. Nesse governo, produz um homem como ser genérico, um mero exemplar. "Ele próprio, enquanto indivíduo, é o absolutamente substituível, o puro nada" (ADORNO, \& HORKEIMER, 1985, p.120). Uma força a se extrair. Um produto, já que "as particularidades do eu são mercadorias monopolizadas e socialmente condicionadas, que se fazem passar por algo de natural” (p.128).

Os produtos da indústria cultural, nesse sentido, são extremidades do poder, ali onde ele se exerce. Um poder que tem como efeito a produção de subjetividades: "gravar sua onipotência no coração dos esbugalhados que se tornaram candidatos a jobs como a onipotência de seu senhor, eis aí o que constitui o sentido de todos os filmes (...)” (p.103). Ao falar dos filmes de animação, dizem que na medida em que eles "fazem mais do que habituar os sentidos ao novo ritmo, eles inculcam em todas as cabeças a antiga verdade de que a condição de vida nesta sociedade é o desgaste contínuo, o esmagamento de toda resistência 
individual" (ADORNO, \& HORKEIMER, 1985, p.114). Dito de outra forma, produtos da indústria cultural atravessam corpos e almas, governando-os, muitas vezes escamoteado a dominação que se opera em nossa sociedade.

Nesse governo, o adestramento da sensibilidade, realizado com cálculos precisos a respeito do enredo, sua montagem, trilha sonora, afinal, a produção de um filme é administrada por especialistas. Novos "engenheiros da alma”, diria Rose (1998). Engenharia que busca não simplesmente reproduzir o mundo da percepção cotidiana, mas o fazer de forma rigorosa, em uma perfeição que almeja tornar o mundo exterior um prolongamento do fundo mostrado em um filme. Quer dizer, um filme busca produzir realidades, as produz, e parece dominar a produção de realidades cada vez mais governadas - ou governamentalizáveis.

Adorno \& Horkheimer defendem que um filme não possibilita mais à fantasia e ao pensamento dos espectadores possibilidades de intervenção, sendo alvos de controles constantes, momento no qual o adestramento ocorreria. Uma certa violência, que atrofia a imaginação, espontaneidade e atividade intelectual. Os filmes, nesse sentido, operariam uma repressão, sobretudo ao proporcionar diversão a seus espectadores. Diversão vista como “o prolongamento do trabalho sob o capitalismo tardio (...) procurada por quem quer escapar ao processo de trabalho mecanizado, para se pôr de novo em condições de enfrentá-lo" (1985, p.113). Momento em que o esforço intelectual seria demasiadamente evitado; momento produtor, assim, de resignação; momento de fuga, não de uma realidade dura, mas da ideia de que é possível resistir e acionar novas realidades.

Que muitos filmes reprimem e, muitas vezes, de forma escancarada, não nos resta dúvida. Mas não se trata de uma manipulação, na qual um espectador - ou qualquer consumidor - acredita "erroneamente" que as escolhas que faz são feitas de acordo com seu verdadeiro desejo, enquanto, na verdade, escolhe o que querem que ele escolha. Pensar 
apenas nesse caráter repressivo da indústria cultural - entendida como uma extremidade do poder - nos faz esquecer do controle sutil ali operado, nas formas pouco visíveis que, ao invés de realizar uma "lavagem cerebral", produzem um cérebro. Isto é, produzem um certo tipo de imaginação, um certo tipo de espontaneidade, um certo tipo de atividade intelectual. Tal entendimento se relaciona a sua ideia de que as pretensões da arte - e da indústria cultural - seriam meramente ideológicas.

Como apontado por Foucault $(1979,2001)$, a noção de ideologia parece restringir nosso olhar, por três razões. Em primeiro lugar, a ideologia nos faz pensar em uma oposição a alguma coisa que seria a verdade, a verdade "real" - ou mais verdadeira; considerar a preexistência de uma verdade nos faz perder de vista como se produzem historicamente efeitos de verdade nos discursos - que, em si, não são nem verdadeiros nem falsos. Como diz Fuganti (2010, informação verbal) ${ }^{11}$, a verdade se refere a um delírio coletivo, necessário a uma determinada ordem social; e onde há uma verdade, o que há é um ponto de vista que quer se tornar universal. Em segundo lugar, a ideologia refere-se necessariamente ao sujeito concebido também como algo preexistente. Finalmente, ela se encontra em posição secundária em relação a uma infra-estrutura, uma macro-determinação (política, econômica, social...).

Nesse sentido, a noção de ideologia faz com que deixemos escapar justamente aquilo que acontece, práticas, extremidades, que não são "acidentais" ou "desvios", um "mau uso" daquilo que "realmente" deveria acontecer; enfim, nos faz perder de vista o nexo criado entre diferentes elementos de um dispositivo, seu funcionamento e seus efeitos, aquilo que é uma verdade do poder, no sentido de lhe ser necessário. Pensar em termos de ideologia é ver já efeitos.

${ }^{11}$ FUGANTI, Luiz. Aula ministrada no curso Biopoder em Foucault, Escola Nômade de Filosofia, 2010. 
Atentando-se para seu funcionamento e seus efeitos, Adorno \& Horkheimer (1985) apontam que a indústria cultural e toda a sua repetição, reprodução, é bastante eficaz na produção de faltas. Oferece uma realidade às pessoas e ao mesmo tempo as priva dela, já que a realidade mostrada em seus produtos dificilmente será alcançada por todos. Faltas, que a retroalimentam, intensificando o consumo. Com isso, intensifica-se sua eficácia e "mais sumariamente ela pode proceder com as necessidades dos consumidores, produzindo-as, dirigindo-as, disciplinando-as e, inclusive suspendendo a diversão" (p.119).

Pensando em seu aspecto produtivo, os autores frankfurtianos entendem o cinema como uma importante instituição de aperfeiçoamento moral. Nele, as pessoas encontram condutas exemplares; nele, exercitam-se as condições de vida autorizada para as pessoas. Quer dizer, o cinema possui uma importante função normalizadora (CANGUILHEM, 2009).

Adorno \& Horkheimer apontam ainda a necessidade de ritmo e dinâmica na cultura atual: "nada deve ficar como era, tudo deve estar em constante movimento" (1985, p.111). Movimento intenso, contínuo, que busca esgotar possibilidades técnicas - relacionadas à ampliação de seu consumo. Idéia que nos faz pensar que, não que o novo deixe de ser buscado, por colocar em risco o estabelecido; pelo contrário, justamente por sempre se por em movimento, mudando continuamente, anula os efeitos de mudança, do novo. O que não muda é a necessidade de criação de estratégias mais eficazes para o governo das almas.

\section{2- Artes e transformações}

Como vimos, com a indústria cultural emergem intensas transformações nas práticas artísticas. Transformações produzidas e a serviço do capital - e da necessidade de maximização da extração de forças da vida. Transformações que se produzem junto com o capitalismo e com suas transformações. Assim, mais do que um efeito do capitalismo, as 
transformações artísticas ao longo do tempo são um efeito-capitalismo, por se darem junto, quase ao mesmo tempo que ele, dificultando, inclusive, separarmos uma da outra (GUATTARI \& ROLNIK, 2005). Isso nos faz pensar, então, que as transformações nas produções artísticas são essenciais na produção deste sistema sócio-político, havendo uma continuidade entre eles. Isto é, as transformações que assistimos a partir da emergência do capitalismo são transformações que se fazem junto ao capitalismo, integram-se. Indivíduo, população, governo... coisas que se entranham ao capitalismo.

Isso posto, acompanhemos, junto com Benjamin (1936 [1994]), algumas dessas transformações no campo das artes. Pensando tendências evolutivas da arte, em um mundo marcado por aquilo que Guattari \& Rolnik (2005) chamaram de modos de produção capitalísticos, Benjamin constata um processo novo, que até o advento do cinema, vinha se desenvolvendo de forma intermitente: a reprodução técnica de uma obra de arte.

Se, com a xilogravura da Idade Média, a reprodução de um desenho se tornou possível, e com a litografia, no início do século XIX, a reprodução possibilitou que ela se desse sob a forma de criações sempre novas e se aproximando da vida cotidiana, foi o advento da fotografia que trouxe um novo status para a reprodução técnica da obra de arte. A fotografia tornou livre a mão das responsabilidades artísticas mais importantes, passadas agora para o olho. "Como o olho apreende mais depressa do que a mão desenha, o processo de reprodução das imagens experimentou tal aceleração que começou a situar-se no mesmo nível que a palavra oral" (BENJAMIN, op.cit., p.167). Ali, na fotografia, se dava um importante passo para o advento do cinema.

O que observamos, segundo o autor, no campo das produções artísticas é uma subversão em seu principal atributo: se antes uma produção artística estava relacionada a rituais e sua autenticidade era necessária, nos modos de produção capitalísticos, o principal aspecto da produção artística passou a ser sua reprodutibilidade técnica, isto é, as maneiras 
pelas quais uma obra poderá ser reproduzida. E esta ênfase transformará toda a função social da arte, de tal forma que a arte contemporânea terá sua eficácia proporcionalmente em função de sua reprodutibilidade.

A arte não seria mais a mesma com as possibilidades crescentes de ser reproduzida. A começar pelo fato de que a reprodução técnica pode colocar a cópia do original em situações impossíveis para o próprio original. Falamos, então, de uma expansão, de novas possibilidades de conexão, nas quais a arte pode se aproximar cada vez mais das pessoas. Além disso, a cópia é dotada de maior autonomia, podendo destacar apenas um aspecto da obra original (como em uma fotografia) ou fixar imagens de forma distinta da ótica natural (através de procedimentos de aproximação ou câmera lenta, por exemplo). E, a cada cópia, uma nova possibilidade de (re)atualização da obra. Deixa, assim, de fazer sentido falar em “autenticidade". Com isso, Benjamin entende que as obras de arte têm a aura atrofiada.

A aura seria como "uma figura singular, composta de elementos espaciais e temporais: a aparição única de uma coisa distante, por mais perto que ela esteja" (BENJAMIN, 1936 [1994], p.170). Em outras palavras, a aura diz respeito à possibilidade de afetação pela experiência, atrofiando-se pelo desgaste causado por uma exposição sem limites, uma espécie de "bombardeio" de cópias, onde quer que estejamos. Atrofiada ou reconfigurada? Com a possibilidade de reprodução, assistimos a novas formas de experiência. Seja uma experiência mais "curta", algo que compreende o esquecimento como parte do processo, uma experiência de curta duração, em que se afeta e isso logo passa, em uma espécie de lampejo; seja na possibilidade da memória concretizada na cópia substituir a experiência sensorial e, com isso, a afetação pode se dar em momentos outros e de maneiras outras.

Agamben (2005), dialogando com Benjamin, aponta para uma certa "pobreza de experiência" da época moderna, pobreza esta, implícita no projeto fundamental da ciência 
moderna. Desconfiada dela, a ciência passa a querer comprovar a experiência em experimentos, procurando eliminar acasos - ou ao menos geri-los - e transformando-os em dados numéricos, calculáveis. A experiência, assim, é transferida para fora do homem, alocando-se agora em instrumentos e números.

A construção de um sujeito único tornou pouco conciliáveis experiência - ligada ao senso comum - e conhecimento; ora, como aponta Montaigne ${ }^{12}$ (apud AGAMBEN, 2005, p.27), o fim último da experiência seria uma aproximação à morte, isto é, “conduzir o homem à maturidade por meio de uma antecipação da morte enquanto limite extremo da experiência". Se o verbo da experiência era ter, o verbo da ciência será fazer - e jamais ter, já que o conhecimento é infinito. Nesse contexto, o autor defende que a experiência na contemporaneidade se efetua fora do homem, que a olha com alívio, já que pode ser gerenciada. As cópias de que fala Benjamin, assim, podem se prestar a isso, possibilitando experiências futuras. Experiências outras, diferentes daquelas de que ele fala, experiências hibernadas na produção de cópias.

Nesse aspecto, se a experiência dizia respeito à aproximação com a morte, em uma sociedade onde dominantemente se faz viver e a morte é aquilo que escapa (FOUCAULT, 1999), não é de se estranhar que a experiência - e a aura das obras de arte - adquira essas novas características. Ora, desde o século XVIII, a ritualização pública da morte vinha desaparecendo e ela foi se tornando algo cada vez mais privado e vergonhoso. Que tipo de preparação para um momento de tamanha vergonha se pode esperar? Assim, é de se esperar que a experiência seja impedida por esse poder que se exerce sobre a vida e interrompe suas intensidades.

${ }^{12}$ MONTAIGNE, Essais. 
Esse declínio da aura, ou sua reconfiguração, relaciona-se à crescente difusão e intensidade dos movimentos de massa ${ }^{13}$, quando novas necessidades são produzidas: as massas passam a ter como necessidade possuir os objetos, em um mundo onde arte também se tornou um negócio. Posse e proximidade; torna-se também necessário que os objetos estejam sempre próximos de si, com ares de familiaridade, superando, assim, as possibilidades de "unicidade" através de sua reprodutibilidade:

Retirar o objeto do seu invólucro, destruir sua aura, é a característica de uma forma de percepção cuja capacidade de captar 'o semelhante no mundo' é tão aguda, que graças à reprodução ela consegue captá-lo até no fenômeno único (BENJAMIN, 1936 [1994], p.170).

Reproduzida, possuída pelas massas, difundida, enfim, exposta. Nesse contexto, passa a dominar o valor de exposição de uma produção artística. E será a exposição que marcará a técnica de produção de um filme cinematográfico; produção esta que não apenas permitirá a difusão de um filme, como a tornará obrigatória. Ora, “o filme é uma criação da coletividade"14 e o caráter artístico do cinema está justamente em sua reprodutibilidade, afinal, um filme não exibido é economicamente pouco viável.

Badiou (2004) também entende o cinema como uma arte de massas. O atributo “de massas" refere-se não apenas à possibilidade da arte poder ser vista e admirada por milhões de pessoas no momento mesmo de sua criação. "De massas" é uma categoria política, politicamente ativa, uma força sobre outras forças. Arte, para o autor, tem a ver com criação, o que, por sua vez, tem a ver com meios para compreender a criação: proximidade com a história da arte, uma certa sensibilidade para a arte. Enfim, aspectos que a tornam

${ }^{13}$ Entendendo por massa algo próximo daquilo que Foucault (2008a) chamou de população, mais uma vez podemos pensar o declínio da aura em um contexto no qual a necessidade de prolongar a vida passa a se disseminar em todo o campo social.

${ }^{14}$ BENJAMIN, op. cit., p.172. 
aristocrática. Falar no paradoxo "arte de massas”, então, é afirmar uma certa democratização de algo aristocrático.

Nesse contexto, o cinema é uma arte de massas, a começar, por se tratar de uma arte de imagem, algo que pode fascinar todos. Cópias do real ou invenção de um real; não importa. Importam as possibilidades de conexão com essas imagens, sendo que dentre elas, sobressaem-se as possibilidades de identificação: o cinema tem uma capacidade infinita para que nos identifiquemos com aquilo que ele supostamente "retrata".

Outra razão para o cinema ser uma arte de massas tem a ver com a maneira como se relaciona com a questão temporal. $\mathrm{O}$ cinema tem a capacidade de transformar o tempo em percepção, quer dizer, é capaz de tornar o tempo visível. Falamos, então, da criação de uma "emoção do tempo", criação esta realizada a partir do momento em que o tempo nos é mostrado, no momento em que nossa vivência do tempo é transformada em uma representação, que será compartilhada por aqueles que assistem um filme.

A relação do cinema com outras artes também traz elementos para o entendermos como uma arte de massas. $\mathrm{O}$ cinema retém das outras artes tudo aquilo que têm, precisamente, de mais popular. Rouba o que há de mais universal, aquilo que se destina à humanidade genérica. Da pintura, rouba a possibilidade da beleza do mundo sensível, isto é, a possibilidade de uma relação sensível e enquadrada com o mundo exterior. "O cinema é uma pintura sem pintura, um mundo pintado sem pintura" (BADIOU, 2004, p.32 - tradução nossa). Da música, retém a possibilidade de acompanhar com encanto o mundo naquilo que ele tem de sonoro, isto é, as emoções musicais relacionadas às situações objetivas da vida. Da novela, retém a forma do retrato. Do teatro, a figura do ator, seu encanto e sua aura, transformando-os em astros e estrelas.

Uma arte ladra, que rouba aquilo que há de mais acessível nas outras artes. Uma arte impura, híbrida, que abre todas as artes, que as populariza, em uma certa vocação para a 
universalidade. Uma arte que quebra o complexo e o aristocrático de outras artes. Uma certa democratização artística.

Uma arte impura e de borda, afinal, o cinema está na borda da não arte. Avizinha a não arte, por ser também carregada de formas vulgares e por sempre explorar, a cada época, a fronteira entre o que é arte e não arte.

Outro aspecto de seu caráter de arte de massas diz respeito a seu alcance ético. $\mathrm{O}$ cinema é a arte das grandes figuras da humanidade em ação, tendendo para a criação de um tipo de cena universal de ação. O cinema transmite uma espécie de heroísmo particular, discutindo grandes valores. É evidente que propõe figuras heróicas, pouco imagináveis sem suas questões morais. Quantos heróis já assistimos? Quantos exemplos do que fazer ou não já não vimos? Quantas lições de vida não recebemos? Enfim, o cinema propõe costumeiramente um grande combate do bem contra o mal.

Como o teatro grego, o cinema propõe a um imenso público figuras típicas e grandes conflitos da humanidade. Propõe, dessa forma, uma espécie de mitologia moral. E é grande a curiosidade em se saber quais as grandes causas que figuram por aí.

Falamos, então, de uma nova modalidade de arte, com novas configurações, novos alcances e, assim, novas funções. Para Benjamin (1936 [1994]), o cinema servirá para

exercitar o homem nas novas percepções e reações exigidas por um aparelho técnico cujo papel cresce cada vez mais em sua vida cotidiana. Fazer do gigantesco aparelho técnico do nosso tempo o objeto das inervações humanas - é essa a tarefa histórica cuja realização dá ao cinema o seu verdadeiro sentido (p.174).

Nesse exercício de novas percepções, o espectador receberá instruções aprimoradas no cinema; instruções precisas e imperiosas. Afinal, "a compreensão de cada imagem é condicionada pela seqüência de todas as imagens anteriores" (BENJAMIN, op. cit., p.175). E 
essas imagens são seqüenciadas através da intervenção de alguém, um montador, um editor, que também pode corrigi-las sem qualquer restrição. Mas isso não quer dizer que tais instruções sejam de autoria de alguém; a configuração de um campo de forças onde se dá a construção desse filme é que conformará tais instruções - que dizem respeito a percepções, atenção, sensações, modos de pensar, agir...

Montagem, filmagem e atuação dos atores passam a ser controladas pela relação estabelecida com a massa, uma das formas presentes nesse campo. E esse controle se dá através de uma autoridade reforçada justamente pela invisibilidade da massa (e de seu consumo do filme, isto é, as possibilidades de bilheteria e de produtos gerados a partir do filme). Da mesma forma, as reações individuais e coletivas a um filme serão condicionadas, desde o início, pelo caráter coletivo dessa reação. "Ao mesmo tempo que essas reações se manifestam, elas se controlam mutuamente", diz Benjamin (1936 [1994], p.188). E, se a forma de percepção se transforma, ao mesmo tempo modos de existência também se transformarão. Nesse sentido, o controle se dá pelas possibilidades de sujeição econômica e subjetivas alcançadas por um filme.

A reprodutibilidade técnica parece se associar à idéia de "cultura-mercadoria", discutida por Guattari na mesa-redonda "Cultura de massa e singularidade", promovida pela Folha de São Paulo em 1982 (GUATTARI \& ROLNIK, 2005).

A "cultura-mercadoria" diz respeito à cultura de massa, quer dizer, aos bens culturais. Trata-se de uma cultura que se produz e reproduz, modificando-se constantemente, cuja função é produzir e difundir mercadorias culturais, seja através de equipamentos, pessoas ou referências teóricas e ideológicas; enfim, tudo aquilo que contribui para a produção de objetos semióticos, isto é, para objetos capazes de produzir sentidos, certos sentidos - não aleatórios -, como um filme. 
Este seria apenas um dos três núcleos semânticos ligados à cultura, núcleos estes que funcionam de modo complementar e simultâneo. "Cultura-valor""15 e "cultura-alma"16 compõem a cultura capitalística. Esta, no entendimento de Guattari, seria a cultura geral, única, que permeia todos os campos de expressão semiótica.

Em uma relação paradoxal, a cultura de massa produz indivíduos, normalizados, serializados, articulados uns aos outros de acordo com sistemas hierárquicos, de valores e de submissão. Sistemas estes, invisíveis, dissimulados. Ao mesmo tempo, a produção da subjetividade capitalística gera uma cultura de alcance e vocação universais. Todos cabem; quer dizer, todos cabem, desde que escapem apenas relativamente à cultura capitalística:

Nas últimas décadas, essa produção capitalística se empenhou, ela própria, em produzir margens, e de algum modo equipou novos territórios subjetivos: os indivíduos, as famílias, os grupos sociais, as minorias, e por aí vai. Tudo isso parece ser muito bem calculado (GUATTARI \& ROLNIK, 2005, p.26).

Cálculo para um controle mais eficaz da população. Cálculo que se faz necessário na sociedade em que vivemos. Cálculo de como se desenharam essas margens entre o dentro e o fora. Para isso, diferentes modos de controle, inseparáveis, passam a se operar, os “controlatos", nas palavras de Deleuze (1992). Diferentes controles, de curto prazo e de rotação rápida; contínuo e ilimitado. Controles como diferentes modulações, que mudam a todo instante, "como uma peneira cujas malhas mudassem de um ponto a outro" (p.221).

15 Com uma função segregativa, correspondente a um julgamento de valor que determina a qualidade da cultura, diferenciando quem a tem ou não.

${ }^{16}$ Trata-se de uma noção pseudocientífica elaborada com o desenvolvimento da antropologia e multiplicadora do etnocentrismo, que se refere às identidades culturais que qualquer pessoa pode ter. 
Modulações que estabelecem uma constante sensação de não se terminar nada nunca, de se estar no meio do processo eterna e universalmente.

Um novo homem é produzido, não mais um homem produtor descontínuo de energia, mas um homem ondulatório, que funciona em órbita, num feixe contínuo. Um homem em dívida, contínua e ilimitada. Bem ao modo do capital.

Enfim, cinema: uma nova arte, de novas percepções, novas sensibilidades, novos alcances, novas conexões. Novos funcionamentos que se produzem com o capital. E que, quando escapam, tendem, todos eles, a serem rapidamente cooptados pelo capital. E tendem a serem postos a serviço do capital. E alguma delas escapam e continuarão a ser cooptadas. E escaparão, em um jogo sem fim, na tentativa de agenciarem-se outros modos de produção de sentido.

\subsection{Paradoxos e criações}

Como um dispositivo, muitos são os paradoxos no cinema, já que faz operar relações entre elementos - heterogêneos e a princípio incomunicáveis - de maneiras não vistas até então. O cinema, na visão de Badiou (2004), criou novas sínteses; criou novas possibilidades

de sínteses. Em outras palavras, o cinema criou novas formas possíveis de relação entre as coisas, justamente ali, onde havia apenas rupturas. $\mathrm{O}$ cinema reconfigura campos relacionais. Ora, faz coexistir arte e não arte, por exemplo, elementos que, a princípio, não teriam nada em comum. Daí sua proximidade com uma experiência filosófica, como defendida pelo autor.

Ao propor novas sínteses diante da ruptura, o que o cinema produz? Que novas possibilidades de pensamento, de afetos, de sensibilidades ele (nos) traz?

A começar, devemos nos atentar para as maneiras como o cinema relaciona as possibilidades de cópia da realidade e a dimensão completamente artificial dessa cópia. Novas 
relações entre aparência e realidade são estabelecidas. E, aí, na visão de Badiou, encontraremos, algo de antimetafísico: o cinema é capaz de mostrar a metafísica e de mostrar, ao mostrá-la, sua desconstrução.

É comum que se pense que uma imagem, seja ela fotográfica ou cinematográfica, seja carregada, em si, de autenticidade. Supostamente uma imagem corresponderia a um registro automático; um documento, resultado do encontro entre lentes (de uma câmera) e o “acontecimento" em si; um registro de uma essência. Diante dessa crença, Xavier (2003) traz à tona a necessidade de que chamemos a atenção para a moldura da imagem. É imprescindível que coloquemos em foco a relação entre a imagem seu entorno, contextualizando sua produção, investigando o campo relacional onde ela se produz. Afinal, "o sentido se tece a partir das relações entre o visível e o invisível em cada situação" (p.32) e não de algum $a$ priori. Dessa forma, ao mostrar a "essência" do acontecimento, a imagem traz consigo toda a relação habitada por esse acontecimento, o que significa dizer que rompe com sua "essência".

Por mais que uma narrativa fílmica possa buscar o caráter universal e, assim, a essência de uma questão, ela tem a possibilidade de mostrar o quão aberta essa questão pode ser. Ora, não falávamos que a cópia alcançava situações inimagináveis para o original (BENJAMIN, 1936 [1994])? A narrativa fílmica, ao abrir uma questão, eleva suas possibilidades de variação. Difícil, então, falar em unicidade e essência. Ao se utilizar de montagens, cambiantes, modulares, fragmentos que podem ser dispostos de diversas maneiras, além de corrigidos ou mesmo extintos da seqüência final, o cinema cria novas realidades. Parece-nos que o cinema corporifica as múltiplas possibilidades de olharmos algo, extirpado de uma suposta existência “em si". Pois bem, falamos de fenômenos que necessariamente habitam uma relação. E, nesse aspecto, vale insistir em nossa concordância com Xavier (2003): as significações se produzem necessariamente por forças de contextualizações. 
No entendimento de Badiou (2004), o cinema se trata de uma arte de purificação e, assim, a "realidade" apresentada pelo cinema diz respeito ao trabalho de purificação operado, que, de certa forma, diz respeito às molduras da imagem, isto é, sua contextualização. Sejamos mais claros. O cinema segue o caminho inverso de outras artes, que partem, já de início, de uma certa pureza e buscam sua conservação. Um pintor, por exemplo, de um modo geral busca conservar o frescor de uma tarde ou a doçura de um olhar em sua pintura. $\mathrm{O}$ cinema, pelo contrário, começa por uma infinidade de impurezas, desordens, excessos, e o trabalho da arte será extrair dessa impureza alguns fragmentos de pureza, uma pureza local, uma certa simplicidade. Quer dizer, o cinema, busca apagar um estúdio de seu filme, microfones, os improvisos do figurino e do cenário, os imperativos da indústria... O cinema seria, então, a arte da simplificação: a criação do nada a partir de uma complexidade:

De modo que é certo que o cinema trabalha com o lixo contemporâneo; é uma arte absolutamente impura, e, por isso também, uma arte do dinheiro. Mas o esforço artístico está em transformar desde o interior esse material e produzir imagens-movimento, imagens-tempo, por um tipo de travessia da impureza. Creio que se aceitarmos essa hipótese, se compreenderá porque o cinema é uma arte de massas. (...) O cinema é uma arte de massas porque compartilha com as massas o imaginário social (BADIOU, 2004, p.69 - tradução nossa).

O trabalho de purificação operado, entretanto, nunca será total; algo sempre escapa. Sempre há um resto, uma impureza que insiste em permanecer. Em qualquer filme podemos encontrar um momento desnecessário, que poderia não estar ali: banalidades, imagens inúteis, diálogos que não modificariam em nada o enredo, erros de montagem, e assim sucessivamente. Basta nos lembrarmos das versões "sem cortes" de tantos filmes. Isso faz parte do cinema, afinal, "o cinema é uma luta contra o impuro" (BADIOU, 2004, p.71 tradução nossa). Quando assistimos um filme não vemos apenas o resultado; vemos a luta 
contra a impureza, a luta pela purificação. Um filme sempre é um produto inacabado, pois, para que essas lutas sejam ganhas, a presença do espectador é fundamental. Por isso, nossa relação com o cinema não é uma relação de contemplação. "Estamos necessariamente na participação, participamos desse combate, julgamos as vitórias, julgamos as derrotas e participamos da criação de alguns momentos de pureza" (p.71). Assim, é também necessário inserirmos o universo do espectador e as perguntas que são dirigidas à imagem, ao tratarmos do contexto da imagem (XAVIER, 2003).

Ao mesmo tempo em que compartilha as impurezas do mundo contemporâneo, podendo reproduzi-las em seu produto final, o cinema também pode criar novas simplicidades. Nesse sentido, o cinema pode apresentar o mundo de maneiras outras, em escalas diversas. Pode propor o tempo, um tempo outro, isto é, pode propor uma nova relação entre a duração pura do tempo e sua montagem. Determina a velocidade do tempo, sua aceleração ou sua lentidão. Brinca com o tempo. Mescla tempos variados. Deixa claro que não há o tempo em si (BADIOU, 2004).

Pode alterar o espaço também, enquadrando, aproximando ou distanciando-o de nós, de acordo com o registro que faz, usando ou não do close-up. É possível um acesso sobre a intimidade das coisas. Lugares passam a existir apenas em uma determinada cena, de um determinado filme, corporificado em um pedaço de uma fachada de prédio ou em um ângulo pouco comum de uma rua, por exemplo, ou na junção de espaços variados ${ }^{17}$.

As criações de realidade operadas pelo cinema não param por aí. Algo chama a atenção na discussão proposta por Badiou. O cinema, para ele, seria um novo pensamento do outro, quer dizer, uma nova maneira de fazer existir o outro:

${ }^{17}$ Difícil não nos lembrarmos do espaço criado por Fernando Meirelles em Ensaio Sobre a Cegueira (Blindness, de 2008). O filme se passa em uma grande cidade não identificada, com ares de universalidade. Uma cidade inventada, onde pontos da cidade de São Paulo, como o Minhocão, Ponte Estaiada e Viaduto do Chá, coexistem com imagens filmadas no Uruguai e no Canadá. 
Há atualmente situações inteiras em que somente conhecemos [o outro] mediante o cinema. (...) $\mathrm{O}$ cinema nos apresenta o outro no mundo, nos apresenta em sua vida íntima, em sua relação com o espaço, em sua relação com o mundo. $O$ cinema amplifica enormemente as possibilidades de se pensar o outro... (BADIOU, 2004, p.56 - tradução nossa).

O cinema nos apresenta mundos diversos, desconhecidos. Pessoas, lugares, situações que, sem o cinema, dificilmente poderíamos conhecer. O cinema nos oferece pontos de vista, colocando-se entre nós e o mundo. Em uma relação entre pessoas, sem esse intermédio, há uma troca de olhares: "o olho que vejo é olho porque me vê, não porque o vejo", como diz o poeta Antonio Machado, citado por Xavier (2004, p.57). Já em uma relação com aparatos de comunicação - como no cinema - a interação seria de outra ordem, envolvendo "um olho que não vejo e não me vê, que é olho porque substitui o meu, porque me conduz de bom grado ao seu lugar para eu enxergar mais... ou talvez menos" (p.57). Isso significa que o cinema pode servir para amplificarmos nossas possibilidades de pensarmos o outro, o mundo. Ou diminuílas.

E o cinema também nos cria, ao nos permitir usufruir de um olhar privilegiado, exterior a nós, mediado pelas lentes da câmera. Xavier fala de um olhar sem corpo, que nos organiza uma aparência das coisas e que nos possibilita o acesso às aparências registradas pela câmera sem o mesmo risco ou poder, isto é, sem a mesma circunstância se estivéssemos diretamente com essa coisa. Olhar prodigioso, marcado pela liberdade no acesso à intimidade das coisas; uma liberdade usufruída sem riscos. Um suposto privilégio: estar presente, sem participar do mundo observado; ver o mundo e estar a salvo. O autor é enfático nessa questão:

Máquina de efeitos, a realização maior do cinema seria então esse efeito-sujeito: a simulação de uma consciência transcendente que 
descortina o mundo e se vê no centro das coisas, ao mesmo tempo que radicalmente se separa delas, a observar o mundo como puro olhar. Nessa competência ilusória da competência ideal do olhar, estou, portanto, no centro, mas é o aparato que aí me coloca, pois é dele o movimento da percepção, monitor da minha fantasia. (...) A engenharia simuladora do cinema define, com o efeito-sujeito, seu teatro da percepção total cujo protagonista sou eu-espectador identificado com o olhar da câmera (XAVIER, 2004, pp.48 e 49).

Novas relações. Com o tempo, com o espaço, com o outro, com o mundo, com o pensamento, consigo mesmo. Novas experiências. Novas possibilidades de subjetivação. Ou não.

\section{4. (Re)Tomando o cinema como extremidade}

Quando nos referimos ao cinema como uma extremidade, referimo-nos a uma extremidade na qual relações de poder se exercem. Um ponto de aplicação do poder. Justamente ali onde o poder se efetua, onde há governo, onde condutas são conduzidas. Uma das lições foucaultianas de maior importância: sempre analisar o poder ali onde ele se opera, em situações cotidianas, quase banais. Analisar como ele funciona. Daí a necessidade de se tomar o cinema como um dispositivo, composto por elementos discursivos e não discursivos, cuja combinação tem efeitos subjetivos.

Entre os elementos não discursivos, temos o processo de filmagem (que diz respeito às opções de como vários registros serão feitos, com a escolha do enquadramento, os movimentos da câmera, por exemplo) e a montagem (a escolha de como as imagens obtidas serão combinadas e ritmadas, conduzindo nossa atenção para diferentes elementos que se sucedem no desenvolvimento de uma ação), conforme discutido por Xavier (2008). 
A preocupação com os efeitos subjetivadores desse processo de filmagem, montagem, reprodução e exibição datam da emergência do próprio cinema. Devemos nos lembrar que $A$ obra de arte na era de sua reprodutibilidade técnica, de Benjamin, fora escrita em 1936. Em A experiência do cinema: antologia, organizada por Xavier (1983), encontramos artigos mais antigos ainda: no começo do século XX, Munsterberg (psicólogo alemão que morrera em 1916) já apontava para movimentos subjetivadores relacionados à organização das imagens, que, por exemplo, guiam nossa atenção para determinados aspectos de um filme. Pudovkin (1926 [1983]) enfatizava que a montagem dizia respeito à "direção deliberada e compulsória dos pensamentos e associações do espectador" (p.62), não se reduzindo a uma mera colagem de cenas e imagens; apontava para um poderoso "método que controla a 'direção psicológica' do espectador” (p.63).

Balázs (1923 [1983]), foi preciso ao apontar uma das intenções da indústria cultural: a construção de uma certa homogeneidade na "gestologia" nas produções cinematográficas, marcadas por gestões e expressões faciais universalmente compreensíveis, facilitando a identificação dos mais diversos espectadores e, assim, possibilitando seu consumo por todos. No mesmo ano, Einsenstein (1923 [1983]) identificava aquilo que mais tarde viríamos a conhecer como governamentalidade. Referindo-se ao teatro, entende que o espectador passava a constituir à época o material básico de um espetáculo e que este sempre deve orientar o espectador para uma direção desejada, para um determinado estado de espírito. Princípio este que será rapidamente incorporado pelo cinema, no trato das imagens.

Inspirado pela psicanálise, Mauerhofer (1949 [1983]) falava da configuração de uma "situação cinema", na qual figura uma alteração da realidade cotidiana, bem como na sensação de tempo e espaço. Alterações que se dão com o espectador, um "ser-testemunha" e um "ser-ajudante", que, ao olhar o filme, ajuda-o a nascer, a viver, já que é no espectador que o filme viverá, como escreveu Metz (1975, [1983]). 
Enfim, uma breve antologia, que nos mostra uma articulação entre todo o aparato técnico do cinema, a engrenagem que envolve o filme, o público, a crítica. Uma integração entre elementos não discursivos e discursivos - informações, saberes, significações que se produzem no cinema, como aquelas discutidas por Xavier (2003) e Badiou (2004). Uma integração com intensos efeitos subjetivadores. Efeitos produzidos em escala industrial, em uma nova indústria, em tempos de Capitalismo Mundial Integrado (GUATTARI \& ROLNIK, 2005).

Nesse novo contexto, Duarte (2008) considera que a indústria cultural mantém princípios de funcionamento, apresentando-os de outras maneiras. A começar pela globalização dos meios de comunicação não se dar de forma recíproca entre os participantes desse mercado, já que assistimos uma tendência à "estadunização" da cultura de massas, isto é, a hegemonia de um produtor cultural e, no caso do cinema, de Hollywood. A integração de conglomerados de indústrias eletrônicas com empresas de comunicação - televisivas e cinematográficas, sobretudo - tem possibilitado um alcance cada vez maior aos produtos culturais, seja pela ampliação da transmissão, barateamento ou desenvolvimento de novas tecnologias, como a internet e a telefonia celular. Nesse movimento, cada vez mais a dominação adquire um poder "físico" de orientar as percepções, em jogos estratégicos que se montam na prática das coisas.

Uma indústria que vende muito mais do que filmes; vende filmes e estilos de vida, maneiras de ser, normas de convivência, construindo e legitimando identidades sociais, ao mesmo tempo em que desautoriza outras. E como aponta Louro (2010, p.426), desde muito cedo se percebeu o potencial formativo do cinema, que se constitui "uma instância que participava de um processo pedagógico mais amplo; uma instância que integrava e interferia nas redes sociais do poder". Cinema, assim, como uma estratégia de pedagogia cultural. 
Pensando na eficiência dessas estratégias, não podemos nos esquecer da televisão, que, “enquanto 'cinema doméstico', está permanentemente à disposição do usuário, além de não se dirigir apenas a um de nossos sentidos" (FRANCO, 2008, p.112). Mais uma extremidade que escamoteia a dominação, reforçando formas de consciência (e ampliaríamos para formas de vida) socialmente predominantes. Extremidade que satisfaz necessidades de indivíduos esgotados pelo processo de trabalho; esgotamento produzido pela lógica da sociedade em que vivemos, onde o aproveitamento de forças da vida deve ser maximizado. Extremidade que instaura formas de socialização planejadas - quer dizer, com um planejamento outro.

Para pensar essa extremidade, onde o poder se exerce, o conceito de "dispositivo pedagógico da mídia”, trabalhado por Fisher (2001, 2002), parece ser de grande potência para o caso do cinema. O interesse da autora diz respeito à investigação de como a mídia participa efetivamente da constituição de subjetividades; uma participação que se dá com a produção de imagens, significações, informações, saberes, que se dirigem à educação das pessoas, ao mesmo tempo em que as capta em sua intimidade. A mídia, nesse aspecto, educa ao ensinar modos de ser e de estar em uma determinada cultura. Dito de outra maneira, a mídia é responsável por uma educação que não diz respeito unicamente à transmissão cultural (e não que o cinema não a faça), como também ao ensino e aprendizagem de modos de existência, modos de se comportar, modos de constituir a si mesmo.

Uma educação que não apenas veicula, como também - e sobretudo - produz discursos, significados, sentidos, sujeitos. Uma educação que ultrapassa os bancos escolares, bancos em crise intensa, em agonia profunda, como dito por Deleuze (1992), ao falar das instituições disciplinares. Como entende Aquino (2004), a educação nesses tempos de agonia só pode se dar em larga escala espaço-temporal. Uma educação que se dá continuamente, de modo versátil, flexível, cambiante, em todo o espaço social. Isto é, uma educação que se 
aproveita, cria e intensifica potenciais dos mais diversos espaços - para além dos muros das instituições. Daí, a possibilidade de uma educação pelo cinema, que se dá "por meio de uma intervenção plástica, volátil, transitória, autovoluntária inclusive” (AQUINO, 2004, p.149).

Uma educação que ultrapassa a mera informação, dizendo respeito também ao ensino e aprendizagem de modos de existência, de se comportar, de constituir a si mesmo. Uma educação que se faz também pela produção e difusão de representações - não no sentido de se contraporem à realidade, constituindo traduções mais ou menos distorcidas de algo préexistente, mas no sentido de constituírem, todas as representações, a realidade (LOURO, 2010). Representações acirradas pelas diversas ramificações da indústria cultural: publicações e programas televisivos sobre astros e estrelas cinematográficas, que buscam unificá-los aos personagens interpretados. Em um duplo movimento, os produtos midiáticos expressam e produzem novas configurações sociais, isto é, são instrumentos poderosos na produção e circulação de valores, concepções, representações relacionadas

a um aprendizado cotidiano sobre quem somos, o que devemos fazer com nosso corpo, como devemos educar nossos filhos, de que modo deve ser feita nossa alimentação diária, com devem ser vistos por nós, os negros, as mulheres, pessoas das camadas populares, portadores de deficiências, grupos religiosos, partidos políticos e assim por diante (FISHER, 2002, p.153).

Enfim, um lugar que educa, que faz justiça, que promove a "verdadeira" investigação dos fatos, que ensina como fazer; enfim, falamos de uma poderosa máquina que fabrica sujeitos, por ensinar modos de ser, pensar, sentir, agir, modos de conhecer o mundo e a si (e de produzir verdades sobre eles), modos de se relacionar (com o mundo, com os outros, consigo). Uma máquina a partir da qual ocorre uma incitação constante ao discurso sobre "si mesmo". Afinal, como relatou Noêmia, uma senhora de 75 anos, entrevistada por Fernandes 
\& Siqueira (2010, p.113), "quando o filme é muito bom, que você se envolve bem, esse momento é de reflexão da própria vida".

Referindo-se à televisão, Fisher (2002) afirma que a exposição dos indivíduos é uma tecnologia que cada vez mais se aperfeiçoa. O uso de estratégias, como a valorização de testemunhos que adquirem um caráter de "lição de vida", a publicização da intimidade sexual $^{18}$ e amorosa das pessoas ou mesmo os recursos de filmagem (posição da câmera, por exemplo) e montagem (com cortes e zoom), os telespectadores são capturados em sua intimidade, produzindo neles "a possibilidade de se reconhecerem naquelas verdades ou mesmo de se auto-avaliarem ou auto-decifrarem com relação àquele tema" (FISHER, 2002, p.157). Estratégias que também assistimos no cinema. Em suma, os produtos midiáticos são importantes tecnologias do eu, que convocam os telespectadores a se confessarem, a buscarem em si uma particularidade com a qual possam se conectar; um modo de capturar o sujeito em suas mais amplas possibilidades de presença. Paradoxal, a mídia particulariza e homogeneíza.

Temos aí, um processo altamente pedagógico, onde verdades sobre e para o sujeito são produzidas. Nesse contexto, o cinema, para Fernandes \& Siqueira (2010), pode ser entendido como uma pedagogia que tem regulado importantes questões referentes à existência humana, seja no que diz respeito a classe social, etnia, religião, sexualidade, gênero. Interessadas em saber o lugar ocupado pela imagem na vida de mulheres idosas - e como elas foram se constituindo enquanto mulheres - as autoras afirmam que

18 Se Foucault (1988) apontou a relevância do sexo na determinação de quem somos, no cinema não será diferente. Como mostra Louro (2010), esse será um dos assuntos posto em voga pelo cinema hollywoodiano a partir da década de 1950, quando a virgindade feminina era uma questão central em diversos filmes, devendo ser altamente vigiada: devia-se não apenas ser virgem até o casamento, como sobretudo aparentar ser virgem. Ao mesmo tempo, domina a construção de uma masculinidade marcada pelos filmes western. 
através da construção de situações e personagens, o cinema cria certas variedades sobre a identidade dos sujeitos, sua sexualidade e identidade e identidade de gênero, que são apropriadas em uma dinâmica que inclui negociação de sentidos, ampliação dos repertórios ou aceitação de determinadas formas de ser como válidas (FERNANDES \& SIQUEIRA, 2010, p.102).

Falamos, assim de um processo de pedagogização - uma educação que se sistematiza, que cria metodologias para diferentes espaços sociais, com estratégias específicas para cada um deles, específicas para o cinema. Uma pedagogização que ensina modos de vida. Uma pedagogização enquanto uma normalização, que ensina e situa os sujeitos dentro de níveis aceitáveis, autorizados de existência, contribuindo (ou não) para a perpetuação de estereótipos e naturalizando modelos. Um artefato sócio-histórico que (re)configura, a cada momento histórico, "perfis" para nossa existência; isto é, que (re)configura o tipo de sujeito que cada época merece, legitimando ou marginalizando-o. Que (re)configura e controla esse tipo, através do oferecimento de palavras-de-ordem procedimentais a serem por nós incorporadas.

\subsection{Para uma extremidade, uma atitude extrema}

(Re)tomar o cinema como uma extremidade significa, assim, podermos identificar o nível micro do poder. Quer dizer, pensar como o poder se infiltra no cinema. É isso que buscamos. Uma busca que se dá na superfície. É nas superfícies, nas extremidades, que é possível vermos o caráter positivo do poder, as formas como produz sujeitos e suas relações consigo e com o mundo; as formas como produz e gere a vida.

Tomando o exemplo de Fisher (2001) ao se referir às feminilidades, nosso desafio será discutir como formas sexuais são "reforçadas, imaginadas, dinamizadas, polemizadas, enfim, construídas na cultura" (p.591). Dito de outra maneira, o desafio é tomar o cinema 
como uma instância para pensar a dinâmica e o funcionamento do poder. Instância que constrói, intensifica ou enfraquece maneiras de pensar, entender, sentir, vivenciar as diferenças sexuais. Instância na qual há resistência, intrínseca às relações de poder (FOUCAULT, 1994). Para isso, uma reeducação de nosso olhar se faz necessária. Mas uma reeducação diferente da proposta por Loureiro (2008), que defende a necessidade de entendermos o papel dos estúdios hollywoodianos na produção de determinadas estéticas hegemônicas nos últimos tempos e, assim, acessarmos a ideologia presente nessas narrativas. A reeducação proposta pelo autor, dessa forma, se aproxima de um processo de conscientização, de forma a interpretarmos melhor uma narrativa, compreendendo-a de forma crítica, emancipatória, rompendo com supostas distorções.

Mas como já apontamos em outros trabalhos (SARAIVA, 2010), é necessário constituirmos um olhar que nos possibilite sairmos do lugar de "decifradores", deste lugar em que nos acostumamos a buscar apreender verdades e definir um possessivo e um pessoal atrás dos indefinidos. Decifrar significa tratar uma narrativa fílmica como mera ilustração daquilo de que se fala, como um decalque, um exemplo que vem a confirmar certas hipóteses, que busca algo por detrás. É preciso ir além:

não se trata de interpretar cada gesto dos personagens, cada fala, e encontrar neles, finalmente, uma explicação causal, a representação de algo que seria exterior à narrativa e às imagens do filme analisado, fatos comprovadores de uma tese que estariam ali expostos, como reprodução de uma dada realidade (FISHER, 2008a, p. 49).

Se não vamos apreender verdades, assumamos, então, que "nada há por trás das imagens, elas valem como efeitos-de-superfície, imagem remetendo a imagem, fluxo de simulacros" (XAVIER, 2003, p. 50). Uma narrativa fílmica simplesmente dispõe de uma determinada maneira acontecimentos a partir de uma ângulo de observação, ângulo este que irá dirigir nosso olhar. Verdades a descobrir? Não mais. Não há referências "reais" ou 
“concretas" a buscarmos. O que há é a função prática de uma narrativa fílmica, isto é, uma produção de realidade.

Mantemos, assim, a exploração crítica de uma narrativa fílmica; ao mesmo tempo, propomos a subversão dessa crítica. Uma exploração crítica que torna necessário e-ducarmos nosso olhar (MASSCHELEIN, 2008). Educar o olhar, como diz o autor, não no sentido de ensinar (educare), que nos remete à conscientização, à interpretação, à busca de uma verdade mais verdadeira do que aquela que nos aparece. Educar o olhar no sentido de e-ducere, desaprisionando nossa visão, conduzindo-a para fora, para a superficialidade. Educar o olhar, isto é, produzir um olhar que procure romper com a unicidade de seu "objeto", rompendo com essências e essencializações. Falamos, então, de uma atitude onde o que buscamos é simplesmente prestarmos atenção:

Atenção é o estado mental (state of mind) no qual o sujeito e o objeto estão em jogo. É um estado da mente que se abre para o mundo de forma que esse possa se apresentar a mim (para que eu possa "chegar" a ver) e para que eu possa ser transformado. A atenção abre espaço para uma possível autotransformação, ou seja, um espaço de liberdade prática (MASSCHELEIN, op. cit., p.36).

Um olhar atento, aberto para o mundo, para as paisagens, exposto ao filme, "para que ele possa se apresentar a nós de forma que nos comande" (p.39). Um comando que nos impulsiona, que aciona e desloca nosso pensamento. Um impulso para nos deslocarmos, "de onde (quem) estamos (somos)" (MASSCHELEIN, 2008, p.39). Um olhar que produz uma atitude de estarmos presente no presente, de tal forma que possamos ser atravessados pelo que vemos, transformados, contaminados. Uma atitude de falta de intenção, de neutralizar a vontade de se submeter a regime de verdade. Uma atitude performática. 
Atitude-limite, muito próxima da atitude de Fisher (2008a), que, ao analisar o filme Pequena Miss Sunshine ${ }^{19}$, procura se deixar tomar pelas seqüências da narrativa, se deixar tomar pelas "imagens-tempo e as imagens-movimento desse filme, no sentido de deixar-nos ser olhados pelas imagens oferecidas pelo cineasta, pelos atores, pela montagem e permitir que esse ato de entrega possa talvez pensar a potência afirmativa da criança" (FISHER, 2008a, p.48). Ou quando se deixa olhar pelos meninos da Cidade de Deus ${ }^{20}$, com seus diferentes olhos, de atores, de crianças, de adolescentes, de personagens (FISHER, 2008b).

Nesse sentido, nossa atitude ao lidar com uma narrativa fílmica procura se aproximar da pedagogia godardiana, tratada por Vasconcellos (2008). Na perspectiva do autor, inspirado em Deleuze, o cinema de Jean-Luc Godard incita um questionamento constante sobre o que são imagens e sobre as maneiras como podemos vê-las, reconhecendo-as para além do enunciável, para além do dizível.

Vasconcellos é claro: a verdade das imagens não está na imagem mostrada na tela, nem mesmo por trás dela (quer dizer, seu sentido ideológico); a verdade do cinema está na junção entre as imagens, "melhor dizendo, no que se dá a ver entre as imagens" (p.160). Um método do "entre"; um método do "E", que trata o cinema não de forma dialética, mas que busca as multiplicidades possíveis, de sensações, de sentidos, de pensamentos. Nesse sentido, trataremos o cinema como uma possibilidade de pensar, de produzir pensamentos e não apenas como uma possibilidade de arte.

Para criar esse "entre", é preciso que criemos fragmentos da narrativa. Fragmentos, pedaços que serão colados em seguida, em um verdadeiro processo de "decupagem", como o utilizado por Fabris (2008): desmancha-se a narrativa para registrar fragmentos selecionados e que comporão conjuntos de significados nos quais será possível lermos diferentes enunciados,

\footnotetext{
${ }^{19}$ Little Miss Sunshine, dirigido por Jonathan Dayton e Valerie Faris, em 2006.

${ }^{20}$ Filme dirigido por Fernando Meirelles, em 2002.
} 
diferentes temas. Em palavras outras, decompor a narrativa, torná-la múltipla, para perguntarmos como o filme funciona, com o que ele funciona e o que ele faz funcionar.

Pelo entre, pelo meio, pela superfície. Assim procuraremos tratar as narrativas dos filmes que aqui utilizaremos. Uma maneira de habitarmos a narrativa buscando suas matérias, suas datas, suas velocidades. Buscando, enfim, "suas linhas de articulação ou segmentaridade, estratos, territorialidades, mas também linhas de fuga, movimentos de desterritorializacao e desestratificação" (DELEUZE \& GUATTARI, 1995, p.11). Quer dizer, buscar seus agenciamentos.

Nessa perspectiva, a análise da realidade de uma narrativa fílmica é a análise de uma realidade radicalmente em devir; é uma criação. Resta-nos, então, inventar uma análise que procure experimentar, entrando em contato com movimentos, que abra passagem para outras conexões, que possa operar rupturas e, recorrendo mais uma vez a Badiou (2004), crie novas sínteses. Uma análise crítica, conectora, plugadora. Um jeito de olhar o filme que mapeie, que crie mapas.

Mapas de superfícies. Mapas que criem superficialidades. Superficialidade entendida como ampliação das possibilidades de conexão. É justamente nas superfícies que se desenham as relações. Trabalhar na superficialidade é explorar o múltiplo. As relações, as rupturas, as bifurcações. Enfim, a dispersão, ali onde antes se supunha unidade e identidade. E, com isso, que se crie um novo filme.

É isso que procuraremos fazer com produções cinematográficas hollywoodianas, indicadas e/ou vencedoras das categorias principais do Oscar (Academy Awards) entre os anos 2000 a 2010. Nosso foco será analisar formas ensinadas de se viver, pensar, sentir as diferenças sexuais, entendendo que, por meio delas, há a construção de modos de sensibilidade e de se portar no mundo. 
PARTE IV- AÇÃO 


\section{5- Pedagogizando as diferenças Sexuais}

E se contássemos uma história vista com os olhos de hoje? Quer dizer, e se contássemos uma história sobre as diferenças sexuais a partir do cinema da última década? Uma história banal, contada em pequenas cenas, cenas de filmes quaisquer. Filmes comerciais, exibidos em grandes salas de cinema, atingindo um público amplo, comum. Filmes que receberam indicações e/ou foram premiados pelo Oscar, considerado o prêmio máximo do cinema. Que história seria essa? Ou melhor dizendo, como seria essa história?

Bem, como Foucault (1988) nos ensinou, a sexualidade é histórica. Uma invenção que responde a problemas específicos de um dado momento histórico, por assim dizer. Assim como as diferenças sexuais. Conhecer as atitudes diante delas, então, requer, necessariamente, que conheçamos as condições que tornam possíveis tais atitudes, tal forma de apreensão das diferenças sexuais. Nesse contexto, assim como Weeks (2002), nossa preocupação não se dirige a buscar aquilo que supostamente causaria tais diferenças, mas entender como algumas formas de sexualidade são privilegiadas, enquanto outras são marginalizadas, discriminadas. Um certo estado de atenção.

Ligeiramente atentos, podemos ver nas últimas décadas um verdadeiro boom de personagens não-heterossexuais não apenas no cinema, como em outros produtos da indústria cultural. Cinema, novelas, séries, talk shows, reality shows. Não que esses personagens não estivessem lá outrora; estavam, quase sempre estiveram. De outras formas, em outros lugares. Moreno (2002), analisando o retrato fílmico ${ }^{21}$ e juízos que vem sendo feitos pelo cinema brasileiro do homossexual entre as décadas de 1940 e 1990, ressalta a dominância de

\footnotetext{
${ }^{21}$ Para o autor, o retrato fílmico diz respeito ao "conjunto de valores conferidos a um determinado sujeito ou segmento da sociedade por uma produção cinematográfica, através da caracterização de seus personagens" (IBID, p.25).
} 
um discurso que carnavaliza personagens homossexuais, formulando paradigmas estereotipados, produtores de preconceitos e intolerância.

Em sua análise, identifica que até meados da década de 1960 este era um tema tabu no cinema brasileiro, pouco existindo como homossexualismo ${ }^{22}$. O que havia era apenas a insinuação de algo engraçado, não necessariamente alguém com inclinações homoeróticas. Os personagens não-heterossexuais, brincalhões e carnavalizados em sua gestualidade, faziam o público rir. Apenas isso. Já a partir do final da década de 1960, sobretudo nos anos 70, a temática homossexual começou a aparecer, além do cinema, na televisão e no teatro. Uma certa mudança, no que diz respeito à visibilidade desses personagens; mas uma mudança que conserva o modo de apreensão desses personagens.

Intensifica-se a carnavalização do personagem gay, apresentado como "afetado, por vezes, malicioso, vivo, porém sempre extremamente ridicularizado e até diminuído como pessoa humana" (MORENO, 2002, p.28). Mais uma vez, domina o uso de um discurso e uma gestualidade exacerbada, estereotipada, repetitiva e que remete à identificação com a figura sexual inversa ${ }^{23}$; enfim, uma gestualidade pouco heterossexual, que, como tal, se configura

um modo de expressão que denigre o papel do homossexual na sociedade, pois, ao criar e depois fazer crer ao público que aquelas personagens são as mesmas da vida real, o que fica é a imagem de um ser ridículo, fraco, sem nenhum estatuto legal dentro da sociedade (p.28).

\footnotetext{
${ }^{22}$ Aqui, mantemos o termo utilizado pelo autor.

${ }^{23}$ Ao se referir a homens homossexuais, de um modo geral, sua gestualidade dizia respeito à gestualidade feminina; no caso de mulheres homossexuais, a gestualidade dizia respeito à masculina. Em ambas as situações, os personagens são apresentados, respectivamente, como uma caricatura feminina e masculina, uma caricatura mal feita, ridicularizada.
} 
Domina, assim, a construção de um modelo padrão estereotipado de personagem, tratado, na maior parte dos filmes, de forma depreciativa, rude ou irreverente. Um modelo ora do tipo "gay clown", ora do tipo "bicha louca", ora depravado, doente ou criminoso. Alienado, de pouca instrução, preocupado apenas com sexo e ascensão social, de linguajar chulo, vulgares, subempregados, perigosos, rebolativos, de voz de falsete, traiçoeiros, espalhafatosos, prostituídos. Essa é a imagem dominante veiculada pelo cinema de então.

No final da década de 1990, mudanças. Conforme Bessa (2007), a temática homo ou a chamada "homocultura" - invadiu a grande mídia. Tempos de gay mainstream (SCWARTZ ${ }^{24}$ apud BESSA, op. cit). Personagens gays e lésbicas passam a povoar o mundo do entretenimento. Povoamento que se relaciona, a nosso ver, com o deslocamento de um outro boom, acontecido anos antes.

Antes de povoar a grande mídia, gays e lésbicas passaram a serem difundidos pelo cinema em festivais temáticos. Assiste-se, assim, um boom de festivais gays e lésbicos de cinema. Festivais que, de um modo geral, buscavam tornar presentes, de modo positivo, imagens relativas ao universo "homo"; uma certa frente àquilo percebido por Moreno (2002) no cinema brasileiro e que, guardadas as devidas especificidades, também era comum no cinema hollywoodiano.

Ao mesmo tempo, tais festivais de cinema constituíam espaços de sociabilidade, de encontro entre lésbicas, gays, bissexuais e transgêneros, de forma a "fazer com que cada um saísse do seu próprio universo - boates, festas e guetos -, criando, em primeira mão, uma tolerância à diversidade interna da "comunidade", cujas diferenças nem sempre foram negociadas harmonicamente" (BESSA, op. cit., p.263). Uma busca por um "comum” entre

\footnotetext{
${ }^{24}$ SCWARTZ, Michael. Resenha de Anti-gay culture, edited by Mark Simpson. The Harvard Gay \& Lesbian Review, vol. 4, ISS2, Apr. 30, Boston, 1997.
} 
tanta diversidade; uma busca por algo que se pudesse (com)partilhar, combatendo sentimentos de isolamento, por exemplo.

Indo além de temáticas sensíveis a questões relacionadas à AIDS, discriminação e solidão - temáticas dominantes quando se falava do universo homo, os festivais passaram a incluir outras marcas de diferenciação do público homo (como raça e classe, novas variáveis na caracterização dessas pessoas), falando também de práticas eróticas e de estilização do corpo (como o sadomasoquismo, fisting ${ }^{25}$, cross-dressing ${ }^{26}$ ). Um passo importante, destaca a autora, para a produção e difusão de "novas subjetividades", configurando também novas formas de prazer, desejo e sexualidade. Um local de encontro, onde seus participantes poderiam se afirmar e se reinventar.

Afirmação de identidades, invenção de novas identidades, combate. Ao mesmo tempo, esses festivais de cinema buscavam romper com certos padrões estéticos utilizados para se falar do universo homo: gays efeminados, cenas eróticas entre mulheres, personagens gays ligados a monstruosidades, fadados a finais trágicos. Buscava-se, assim, “construir uma auto-representação, cuja aposta política estava vinculada ao compromisso de subverter a imagem hegemônica veiculada sobre a homossexualidade pela indústria cinematográfica" BESSA, 2007, p.266). Quer dizer, esses festivais buscavam se contrapor a práticas homofóbicas, que difundem e ridicularizam estereótipos, práticas que se dão em um mundo na qual a heterossexualidade é tida como norma. Para isso, também buscavam a produção de conhecimentos sobre o "eu", sobre o "eu homo", no momento da exibição de filmes e após ela, com a realização de debates, de intenso caráter formativo e politizante. Uma produção

\footnotetext{
25 “O Fisting ou Fist-Fuck é uma prática sexual que envolve a inserção da mão, algumas vezes do braço, no anus, reto e intestino (quando anal) ou vagina, seja em parceiros hetero ou homo (masculinos e femininos)" (BESSA, 2007, p.263).

${ }^{26}$ No cross-dressing ou $C D$, a pessoa se veste e utiliza objetos e adereços associados ao sexo oposto.
} 
identitária, afinal, que buscava, de certa forma, uma conformação a novos padrões. O homo, ora, também se torna um padrão.

Bem, como vimos outrora, aquilo que se põe à margem costuma ser trazido para dentro o quanto antes. Capitalismo Mundial Integrado, rizomático, pois (PELBART, 2003). Se nesses festivais críticas passaram a serem feitas, podemos supor que elas não apenas foram incorporadas ao cinema convencional, como ganharam novas utilidades. Parece pouco acidental a presença crescente de personagens não-heterossexuais no cinema hollywoodiano da última década. Beleza americana, Meninos não choram, Longe do paraíso, O segredo de Brokeback Mountain, Milk - a voz da igualdade, Preciosa: um história de esperança: alguns exemplares de filmes de grande sucesso no circuito comercial, na sua maioria, vencedores das mais importantes categorias do Oscar.

Filmes quaisquer. Aproximando-nos deles, nos distanciaremos. Procuraremos um deslocamento, operando uma certa fratura, entre o que é visível e aquilo que está à sombra. Uma sombra cheia de movimentos; cheia de não-vistos, de não-vividos. Um filme não-visto, então, será a nossa procura. Um filme atual que dialoga com tempos outros, que nos ajuda a contar uma história não contada, uma história inédita. Uma tentativa, enfim, em sermos contemporâneos (AGAMBEN, 2009).

Nos filmes, uma história que pode nos ajudar a pensar o caráter educativo do cinema diante da questão das diferenças sexuais. Filmes que nos fazem pensar em algumas temáticas; temáticas educativas. Em lições ensinadas. E lições a serem aprendidas. Por todos nós. Vamos a elas. 


\section{1- Primeira Lição: a descoberta de si}

$\mathrm{Na}$ análise dos filmes em questão, uma temática chama a atenção logo de início: a "descoberta" de alguns de seus personagens como supostamente não-heterossexuais. Uma certa percepção inicial de si, de algo que vem "de dentro", das entranhas de seus personagens.

Uma descoberta que pode ser vista em O segredo de Brokeback Mountain, cujo enredo começa em 1963, quando Jack Twist e Ennis Del Mar, dois típicos cowboys estadunidenses, se conhecem ao iniciar um trabalho pastoreando um rebanho de ovelhas na montanha que dá nome ao filme. Durante a jornada, passariam os dias juntos e se separariam durante a noite: um deles - Ennis - deveria dormir junto às ovelhas, evitando a presença de qualquer coiote, enquanto o outro dormiria em um acampamento determinado pela guarda florestal.

Os dias são silenciosos, com conversas de poucas palavras. Em uma noite de bebedeira, Ennis não consegue voltar para a barraca junto ao rebanho, dormindo no acampamento. Ele se propõe a dormir a céu aberto, próximo à fogueira, mas, devido ao frio, Jack o convida a dormir com ele na barraca. Durante a madrugada, Jack acorda e envolve o braço do amigo em seu corpo. Após um momento de estranhamento, em que sobretudo Ennis reluta, eles transam.

Na manhã seguinte, Ennis, culpado com o que acontecera, descobre que uma ovelha fora morta. Uma noite de descuidos, consigo e com as ovelhas. Trocam poucas palavras, dizendo que aquilo não voltaria a acontecer. Na mesma noite, porém, Ennis procura Jack e os dois passam a noite juntos, em meio a beijos e carícias.

Nos dias seguintes, a relação dos dois se torna cada vez mais intensa. Parecem à vontade entre si, agindo como um casal qualquer, em plenas férias. 
Depois de uma tempestade, em que mais uma vez se descuidaram das ovelhas, o rebanho se mistura a um outro. Novo descuido, que levará ao fim de suas jornadas como pastores. Uma separação forçada, o que os faz discutirem e brigarem, tamanha decepção. Depois de se despedir de Jack, sem saber se voltariam a se ver, Ennis tem um acesso de raiva.

A partir daí, a trama gira em torno dos encontros e desencontros entre Ennis e Jack. Um romance que dura quase vinte anos, com idas e vindas, no qual a ilegitimidade e a impossibilidade em assumirem o relacionamento dará sua tônica.

Em todo o filme, uma contraposição entre Ennis e Jack. É Ennis, sempre de poucas palavras, um tanto quanto reservado, que resiste à investida de Jack e quem mais se incomoda por terem transado. Ao longo do tempo, sempre resiste às propostas de Jack em viverem juntos, assumindo esse relacionamento. Resiste não apenas a isso; parece resistir a algo da ordem de seus impulsos e sentimentos; resiste àquilo que ele verdadeiramente é - ao menos supostamente.

Tenta a vida casado e, de alguma forma, acostuma-se a ela. Carinhoso com a esposa; dedicado aos filhos. Tudo vai razoavelmente bem, até as aparições de Jack. Mesmo quando se divorcia, tenta um novo relacionamento, com uma garçonete.

Jack, por sua vez, mantém um casamento claramente de fachada. Infeliz com a esposa e as constantes humilhações por parte de seu sogro, busca, em diversos momentos, outros homens. Se Ennis não pode estar com ele, ultrapassa a fronteira e, no México, contrata garotos de programa. Paquera em bares, paquera em jantares - a ponto de começar um romance com o marido de uma amiga de sua esposa.

É em Jack que vemos um grande paradoxo. É ele quem deseja assumir seu desejo e seu relacionamento com Ennis. Deseja assumir e dar visibilidade. E é ele quem paga por essa visibilidade, sendo brutalmente assassinado. Sair do armário, ou dizendo melhor, sair do armário da forma pela qual Jack saiu parece ter lhe custado a vida. E Ennis, que nunca 
conseguiu se assumir completamente, atravessado pela lembrança de um casal homossexual brutalmente assassinado em sua infância, terminará sua vida sozinho, solitário.

Entendendo o "armário" como um dispositivo de regulação da vida de nãoheterossexuais, Sedgwick (2007) considera-o como a estrutura definidora da opressão gay no último século. Um indicativo da homofobia, imagem de uma opressão diferente de outras opressões. Uma opressão silenciosa, solitária, baseada e produtora de invisibilidades, no cerceamento de expressões e existências. Uma opressão que produziria inexistências, isto é, seres que pouco existem.

Bourdieu (2010), ao falar da dominação simbólica vivida por homossexuais, entende que estes são marcados pela possibilidade em se ocultar e se exibir. Uma importante diferença em relação a outras forma de dominação, relacionadas, por exemplo, à cor da pele. Supostamente, homossexuais podem ou não se mostrarem como tais, diferentemente de uma pessoa negra, que não tem como ocultar a cor de sua pele. A dominação de homossexuais impõem-se, segundo o autor, através de atos coletivos de categorização, atos estes que marcam de forma negativa diferenças significativas e negam sua existência pública, visível. Uma opressão com ares de "invisibilização", que recusa uma existência legítima, pública. Se pouco existem - já que pouco visíveis - sair do armário e assumir-se publicamente como nãoheterossexual seria, assim, uma maneira de não apenas romper com uma "privacidade" compulsória, como enfrentar privilégios heterossexuais de visibilidade e hegemonia de valores.

Sair do armário, assim, requer diversos enfrentamentos. Enfrentamentos que começam em si, com um auto-exame detalhado, que busca vasculhar verdades interiores.

Como nos ensinou Foucault (1988), o "sexo" agrupa elementos anatômicos, funções biológicas, condutas, sensações, prazeres em uma unidade artificial, um significante único, de significado universal. Uma ideia inventada, um ponto fictício por onde devemos 
necessariamente passar para acessarmos nossa inteligibilidade. Quer dizer, um ponto que devemos examinar para descobrir quem realmente somos. Ou supostamente somos. Algo que convida ao autodeciframento e autoformação; algo a ser confessado, visando instaurar um "em si mesmo" em nós, sob o argumento de que esta seria uma forma de garantirmos nossa felicidade e liberdade.

Sair do armário, nesse sentido, requer certezas, requer verdades. Não se deve correr riscos, assumindo-se ser algo que não se é verdadeiramente. Daí, a busca pela verdade, a verdade do sexo. A verdade de uma identidade coerente; é isso que se busca: um encontro revelador com uma essência, uma verdade escondida, um certo “eu” verdadeiro, genuíno. Sair do armário, assim, seria encontrar tal verdadeira essência, bem como assumi-la. Sair do armário no sentido também de assumir um certo comportamento sexual, comportamento este que é também "a consciência que a pessoa tem do que está fazendo, do que ela faz com a experiência, e também o valor que atribui a ele" (FOUCAULT, 2000, p.12).

Um enfrentamento no qual a autoridade do sujeito é muitas vezes colocada em xeque. Sedgwick (2007) lembra que, no processo da auto-revelação gay, frequentemente são propostas perguntas do tipo

"Como você sabe que é realmente gay? Por que a pressa de chegar a conclusões? Afinal, o que você diz se baseia apenas em poucos sentimentos e não em ações reais [ou, alternativamente, em algumas ações e não necessariamente em seus verdadeiros sentimentos]; que tal falar com um terapeuta e descobrir?” (p.37)

Algo que remete ao que aconteceu com Frank Whitaker, personagem de Longe do Paraíso. Ambientado na década de 1950, em Connecticut, o filme conta a história de Frank e Cathy, um casal modelo de classe média. Frank é executivo de uma grande empresa da 
cidade, enquanto Cathy é uma típica e exemplar dona de casa, esposa e mãe, sempre dedicada à casa, marido e filhos.

Um casamento aparentemente perfeito, não fosse Cathy, zelosa como sempre, querer agradar o marido e levar-lhe o jantar em mais uma noite na qual ele estaria fazendo serão. Ao chegar em sua empresa, Cathy se deparara com Frank nos braços de um homem.

Em casa, momento de confissão. Frank confessa o sofrimento em já ter vivenciado outrora sentimentos e atrações dessa natureza. Algo com o qual ele vinha convivendo, na esperança de superação com a vida familiar. Compreensiva, Cathy propõe que o marido busque a ajuda de um psiquiatra, apoiando-o durante o tratamento.

Tempos depois, o casal sai de férias. Em Miami, Frank conhece um jovem e se apaixona por ele. De volta para a casa: uma constatação: converter-se, deixando de lado seus impulsos e desejos por homens são seria possível. Divorcia-se de Cathy e decide viver sua vida mais livremente. Fora do armário, enfim.

$\mathrm{Na}$ descoberta de si, a presença de especialistas psi. Engenheiros da alma, como sugere Rose (1998), capazes de acessar nossas verdades e transmutá-las, caso necessário. Pois uma verdade como esta, ligada a perversões do pior tipo, há de ser tratada. Como veremos adiante, entendeu-se a homossexualidade como uma doença mental até bem recentemente. Mas a operação que se dá em sua alma diz respeito à legitimação de um desejo que foi por tanto tempo mascarado.

No processo de se descobrir, Paiva (2007) aponta a presença de uma prática de "marranismo" mínimo pressente, que não é. Em sua pesquisa, na qual busca caracterizar a intimidade das parcerias homoeróticas masculinas, o autor identifica na trajetória do se assumir uma

27 O termo diz respeito ao "fenômeno da conversão forçada dos judeus portugueses ao catolicismo, a partir do final do século XV. Os marranos viam-se divididos entre um pertencimento simulado (ao catolicismo) e a manutenção de sua fé (judaica)” (IBID, p.27). 
metafísica do ser/não ser, marcado por um período de indistinção, sobretudo da fronteira entre ser e não-ser. Uma indistinção que tende à afirmação da certeza daquilo que se é (nãoheterossexual), possibilitando construir uma relação de transparência consigo e com os outros. Para isso, uma série de negociações, a partir do acúmulo de "evidências". Evidências de si. Uma aproximação crescente com essas evidências. Um si que vai sendo desvelado pouco a pouco, a partir de experimentações amorosas, sobretudo.

Sair do armário é uma situação um tanto quanto delicada, relembra Sedgwick (2007), já que dificilmente aquele que se assume tem condições de controlar a multiplicidade, ambivalências e contradições presentes na transmissão da informação a respeito da identidade e atividade sexuais. Ainda, diz a autora, assumir-se é uma questão, talvez na maioria dos casos, “de intuições ou convicções que se cristalizam, que já estavam no ar por algum tempo e que já tinham estabelecido seus circuitos de força de silencioso desprezo, de silenciosa chantagem, de silencioso deslumbramento, de silenciosa cumplicidade" (p.38).

Sem controle sobre a saída do armário, a revelação feita pode ser muitas vezes ameaçadora, prejudicial àquele a quem se confessa. Ennis, que, sem saber (e sem ter saído do armário), fora surpreendido pela esposa aos beijos com Jack é inquirido por ela, anos depois. Inconformada, ela o acusa. Uma sensação de que ele não poderia ter feito "isso" com ela.

Nossa primeira lição com os filmes: sair do armário e assumir desejos é uma tarefa árdua, porém necessária. Se necessária, não suficiente. Um primeiro passo para a construção de uma certa unicidade pessoal. Mas, como veremos, não basta descobrir a si mesmo e sair do armário; há de se sair de determinadas maneiras. 


\section{2- Segunda Lição: como sair do armário}

Uma vez reconhecidos os desejos sexuais, o que fazer com eles? A defesa em $O$ segredo de Brokeback Mountain e Longe do paraíso parece tender para a legitimação desses desejos, para que sejam devidamente assumidos, para que se deixe as sombras. Uma nova modalidade de "coming out", isto é, o início de uma "carreira homossexual", que, segundo Pollak (1987), inicia-se pelo reconhecimento desses desejos e aprendizado de lugares e modos de encontrar parceiros. Mas um coming out que deve obedecer a algumas regras.

Milk - a voz da igualdade é uma cinebiografia de Harvey Milk, ativista gay estadunidense, assassinado em 1978, por um desafeto político. Milk foi o primeiro homem abertamente gay a assumir um cargo público em São Francisco, Califórnia. Alguém que se contrapôs à violência e repressão sofrida por gays, violência esta assistida logo no início do filme, com imagens de homens sendo presos em bares e notícias de jornais que falam sobre a brutalidade da polícia diante dos gays.

Ao cinebiografar a vida de Harvey, uma aparente convergência entre sua vida pessoal e sua vida política. Convergência pequena, já que o foco parece ser sua história de militância. Algumas pitadas de sua vida pessoal, como a mudança, no início da década de 1970, de Nova Iorque para São Francisco com Scott, seu companheiro, um rapaz mais novo que conheceu após o abordar abertamente nas escadas do metrô, às vésperas de seu aniversário de quarenta anos. Mudança de cidade e de vida: em um relacionamento estável, deixa seu trabalho e seu terno de lado, tornando-se um hippie de cabelo desgrenhado. Em sua nova cidade, abre uma loja de produtos fotográficos e, resistindo às discriminações, ajuda a tornar o bairro do Castro um local frequentado por gays de todo os EUA. Uma espécie de oásis, que atraía gays em busca de uma vida mais livre e, ao mesmo tempo, anônima. 
Popular e carismático, Harvey ingressa na carreira política, buscando enfrentar a repressão contra homossexuais. Após três derrotas, finalmente Harvey é eleito supervisor. Em seu mandato, milita a favor dos direitos de gays. Essa parece ser uma característica de Harvey: sempre se aproveitar de situações para a militância e a busca por novos aliados.

Uma das grandes batalhas de Harvey disse respeito ao enfrentamento da chamada "Proposição 6", do senador John Briggs. Uma proposição que previa a demissão de todos os professores homossexuais, sob a acusação de que se tratariam de pervertidos ocupados com o abuso sexual e o aliciamento de crianças e adolescentes para o modo de vida homossexual. Passa a comandar uma campanha para que pessoas saiam do armário e se assumam publicamente, considerando que a privacidade, naquele momento era inimiga. Uma forma de dar visibilidade a pessoas que existem e, assim, atrair votos para a causa. Consegue debater tal proposição com Briggs, proposição que seria derrotada, com ampla vantagem em São Francisco.

Na vida apresentada de Harvey, uma grande convergência, sobretudo entre dois aspectos: a afirmação de sua identidade sexual e a militância. Emparelhamento entre identidade e militância; emparelhamento usado como arma política em um mundo marcado por intensa violência contra não-heterossexuais.

Aqui, um desdobramento. A afirmação identitária deixa de ser relevante em sua suposta função libertadora, como defendida outrora. "Sair do armário", dar visibilidade, assume também uma função de resistência, estratégica no enfrentamento de um mundo heterocentrista.

Quando falamos em "heterocentrismo", referimo-nos à ideia de que a heterossexualidade se põe não apenas como uma norma social, mas como a norma social a partir da qual outras formas de sexualidade serão definidas. Partindo-se da heterossexualidade, então, a homossexualidade é entendida como uma forma anormal de 
sexualidade. Anormal por seus comportamentos e identidades sexuais se distanciarem da norma, por se contrapor a ela. Uma institucionalização da heterossexualidade, quer dizer, de afetos dirigidos a pessoas de outro sexo. Uma institucionalização compulsória, que a coloca não simplesmente como uma possibilidade, mas como uma regra a ser, necessariamente, seguida (WEEKS, 2007).

Contrapor-se a concepções e práticas heterocentristas, assim, seria uma maneira de afirmar uma existência e afetar o status quo, a ordem do dia. Isto é, a norma do dia. Uma tentativa de se pluralizar uma norma intensamente monolítica. Um luta que vai se configurando cada vez mais como uma tentativa de se dar voz àqueles que costumeiramente são silenciados, como se dar voz a quem foi silenciado necessariamente significasse dar voz àquilo que foi silenciado, quer dizer, a forças a que tenta aniquilar. Intensificam-se os ares de uma dicotomia entre dominados e dominadores, já que a luta acaba focando quase que um grupo - os heterossexuais. Foca-se um grupo, não necessariamente práticas que produzem a distinção nesses dois grupos. Ao mesmo tempo, uma maneira de afirmar uma existência e, assim, lutar pelo direito dessa existência existir. Um certo reconhecimento de si a partir de respostas afirmativas diante daquilo que interpela o indivíduo, estabelecendo sentidos de pertencimento a um grupo social de referência e afirmando-se positivamente um tipo de consciência a respeito de afetividades, amores, desejos, relações sexuais, (FOUCAULT, 1975; LOURO, 2007). Esses são os contornos que a luta contra um mundo heterocentrista parecem ir ganhando.

Com isso, uma derivação. Agora, uma ideia de que se tornar gay exige não apenas a prática do sexo, mas sobretudo a participação em um certo modo e estilo de vida, em certas comunidades e regras. Sair do armário, pois, para si e para o mundo. Como lembra Sedgwick (2007), o armário gay é para muitos a característica fundamental da vida social. Armário com importantes funções formadoras, subjetivantes, isto é, um dispositivo que produz uma intensa 
percepção de si marcada por sensações da pior espécie. Culpa, nojo, repulsa. Sensações que determinam muitas vezes a impossibilidade de desvelamento de si e um desvelamento atravessado pela sensação de culpa, nojo, repulsa. (PAIVA, 2007).

A criação de novas possibilidades de sociabilidade e experimentação, assim, seriam fundamentais para a saída do armário. Mais do que atividades ou desejos sexuais; para a construção de uma identidade, espaços e redes sociais; pertencimento. Uma ideia de escolha, de opção; não do desejo, mas do tipo de vida que se quer levar.

Sair do armário para enfrentar uma sociedade na qual não-heterossexuais deixam de gozar dos mesmos direitos por conta de sua orientação sexual. Uma sociedade na qual suas formulações judiciais oprimem "sistematicamente as pessoas, identidades e atos gays ao solapar, por meio de limitações contraditórias ao discurso, as bases de sua própria existência" (SEDGWICK, 2007, p.26).

Como dissemos anteriormente, falamos de uma opressão produtora de inexistências, que produz seres que pouco existem. E, se pouco existem - já que pouco visíveis - sair do armário e assumir-se publicamente como não heterossexual seria, assim, uma maneira de não apenas romper com a "privacidade" compulsória, mas salvar-se, ao afirmar uma existência e, assim, poder garantir direitos. Essa parece a estratégia apresentada pelo filme, quando Harvey incentiva que gays se assumam e tragam para a causa familiares, amigos, conhecidos. Uma certa progressão geométrica na angariação de novos parceiros nessa luta pelo reconhecimento de direitos.

Sem dúvida, falamos de uma luta legítima, contra um funcionamento que busca controlar e condenar quaisquer manifestações públicas de comportamento não apenas homoerótico ou homo-social, mas grande parte daquilo que é considerado não-heterossexual. Uma situação também conhecida pela sociedade brasileira, cujo aparato judicial dos séculos XIX e $\mathrm{XX}$, apesar de ter descriminalizado a sodomia, mantiveram critérios abrangentes, de tal 
maneira que

a polícia e os juízes podiam punir ações "inapropriadas" ou "indecentes" que não se conformassem com construções heterocêntricas. Outra medida para regular manifestações públicas de homossexualidade era a de acusar pessoas de vadiagem. A polícia podia prender qualquer pessoa que não tivesse como provar sua subsistência ou domicílio certo, ou "prover a subsistência por meio de occupação prohibida por lei, ou manifestamente offensiva da moral e dos bons costumes" (GREEN, 2000, p.277).

Mas, se no caso brasileiro, oficialmente a homossexualidade não era tecnicamente ilegal - não que isso tenha grande relevância na concretude da vida cotidiana - no caso do filme, falamos da oficialidade da criminalização de comportamentos não-heterossexuais. Oficialidade que pouco importa, já que em ambos os casos, a polícia possuía um certo poder extra-oficial e arbitrário de encarcerar "homossexuais que expressassem publicamente sua feminilidade, usassem roupas ou maquiagem feminina, ganhassem a vida através de prostituição, ou que usassem um cantinho escuro de uma praça pública para um encontro sexual noturno" (GREEN, 2000, p.277). Enfim, códigos criminais cujo lastro se dá com noções vagas de moral e decência pública.

Violência policial, com o cerceamento da livre expressão; crimes de motivação homofóbica marcados pela impunidade; violência familiar, na exclusão de entes nãoheterossexuais e a busca de tratamentos médicos; violência do Estado, que tenta proibir a existência de, por exemplo, professores não-heterossexuais. Violências das mais diversas formas.

Violência denunciada, por exemplo, no filme Meninos não choram. Baseado em uma história real, o filme se passa em 1993 e conta a história de Brandon Teena, um jovem transexual. Passando-se por um garoto, Teena desperta a raiva das pessoas quando descobrem que ela é, "na verdade", uma garota. Já fora internado em um hospital psiquiátrico por sua 
mãe e seu primo quer que ele se assuma "sapatão". Pensa em fazer a cirurgia para mudança de sexo, mas não tem dinheiro para isso.

Ao conhecer um grupo de jovens em um bar, passa a fazer parte da turma. Logo se apaixona por uma das integrantes, Lana, com quem começa a namorar. Após um incidente de trânsito, acaba sendo preso e descoberto como biologicamente mulher.

Se para Lana tal descoberta tem pouco valor, pois o que importava era o sentimento que tinha por Brandon, esta não será a reação de seus amigos. Atormentados, cobram explicações dele, agora considerado uma aberração. Queriam saber se ele era uma garota ou não. Inconformados, espancam e estupram Brandon.

Depois de ser levado para o hospital, Brandon vai para a delegacia, onde é inquirido sobre o que aconteceu, tendo de responder a perguntas constrangedoras, que pouco se relacionavam às agressões que sofrera. Antes de conseguir fugir para sua cidade-natal, é surpreendido pelos então amigos, sendo morto a tiros.

Filme-denúncia. De situações usuais, frequentes e, muitas vezes, consideradas pouco relevantes, por falar da morte de quem poderia morrer, de quem até fez por merecer morrer, já que mentiu, enganou, se fez passar por alguém que não era. Mesmo quando não se "mente", como no caso de Brandon, há quem saia por aí expondo aquilo que deveria ser reservado à intimidade, às quatro paredes de seu quarto. Pensamento, então, que justifica a exclusão e aniquilação. Concepções e práticas contra as quais lutar.

Uma luta legítima. Pouco cabe questionar a luta contra essas formas de violência. Uma luta, entretanto, na qual chama a atenção as armas utilizadas. Na tentativa de romper com o código cultural que diz "pode fazer o que você quiser, mas não diga nada a ninguém" (GREEN, 2000, p.291), a afirmação de uma identidade. Como lembra Louro (2007, p.16),

Os grupos sociais que ocupam as posições centrais, "normais" (de gênero, de sexualidade, de raça, de classe, de religião etc) têm 
possibilidade não apenas de representar a si mesmos, mas também de representar os outros. Eles falam por si e também falam pelos "outros" (e sobre os outros); apresentam como padrão sua própria estética, sua ética ou sua ciência e arrogam-se o direito de representar (pela negação ou pela subordinação) as manifestações dos demais grupos.

É disso que se trata o heterocentrismo. Normas que se aplicam a todos, independentemente se são ou não heterossexuais. Obrigatoriamente, a heterossexualidade se torna referência. Uma referência a ser contestada, então.

Uma identidade que contesta. Contestação da hegemonia de certas identidades. "Uma luta para expressar uma estética, uma ética, um modo de vida que não se quer “alternativo" (no sentido de ser "o outro"), mas que pretende, simplesmente, existir pública e abertamente, como os demais" (LOURO, 2007, p.30). Da denúncia de violências sofridas à luta. Uma quebra na posição de vitimização. Da visibilidade dessa identidade à criação de ativistas. Uma mudança nessa auto-identidade, na qual sair do armário inclui uma posição política. Pequenos messias. Às armas.

Segunda lição: a arma a ser utilizada contra um mundo que oprime se esconde debaixo de nossa pele, em nossa pele. Descobrir nossos desejos sexuais, assim, significa descobrir armas a serem utilizadas em uma importante luta. Armas que devem ser associadas aqueles que também as possuem.

\section{3- Terceira Lição: fora do armário}

Enfim, fora do armário. Do lado de fora, de posse de uma identidade - uma arma a ser usada a seu favor -, em uma certa comunidade, com certas pessoas. Enfim, livres. Quer dizer, uma liberdade dentro de novas regras. A começar pela identidade a se assumir. Não 
basta assumir uma identidade não-heterossexual e afirmar um certo desejo; há que se assumir uma certa identidade.

Frank, Jack, Ennis, Harvey, Scott. Algo os liga. Uma certa masculinidade. Um certo desconto para Harvey e seus trejeitos e voz mais em falsete; características que ficam menos acentuadas com a intensificação de sua carreira política e as transformações que sua aparência sofre. Falamos da presença de uma identidade gay, identidade esta construída ao redor da masculinidade de dois homens que desempenham "papéis de homens". Quer dizer, mais do que a presença de uma certa masculinidade, a eliminação de traços de feminilidade, de um “homem efeminado" ou de "uma mulher que não deu certo" (POLLAK, 1987).

Em reação ao modelo de outrora, a "bicha louca", homens viris. "Machos". Jack e Ennis, cowboys, são imagens míticas na imprensa homossexual; virilidades outrora a serviço da pornografia, em $O$ segredo de Brokeback Mountain falam de um novo modelo homossexual. Algo como se a fantasia tivesse virado realidade.

Homem com homem. "Gay que transa com gay", algo de vanguarda, imposta por intelectuais do teatro, como disse Clóvis em entrevista a Perlongher (2008). Homens que desempenham no ato sexual tanto o papel feminino quanto o masculino; homens masculinizados, versáteis, "flex", na linguagem atual. Um modelo novo, já que se pressupunha uma certa divisão de papéis no relacionamento entre homens, com a presença de um "macho" e uma "maricona". Algo novo e estranho, que vai enfatizar, cada vez mais a necessidade de ser pouco afeminado.

Perlongher (2008), reconstruindo a história do gueto gay paulistano, recorreu a depoimentos de homens não-heterossexuais que frequentavam espaços de homossociabilidade desde os primórdios da década de 1960. Nesses depoimentos, uma observação: "a tônica gay, antes de 1967, era enrustida e não-assumida. Era uma sociedade secreta, entendida" (p.96). Apesar da presença de travestis e "bichas pintosas", dominava ares de segredo. Apenas na 
década de 1970, surge o gay como personagem, marcadamente alguém de classe média, intelectualizado, macho (no sentido de pouco afeminado). Importa ser macho, a ponto de "um cara desmunhecar ou ser muito mulher não tem praticamente chance de trepar nesses ambientes gays" (p.100).

Na construção dessa nova identidade, assim, uma nova inversão: se antes, era necessário que uma das pessoas, a "bicha", fosse feminina ao máximo para atrair um parceiro macho, no modelo gay/gay, ambos procuram ser o mais masculino possível para seduzir parceiros ainda mais masculinos. Um modelo mais "igualitário", no qual se desestimulam extremos caricatos, sejam eles de macheza e feminilidade, ou, nas palavras de Perlongher (2008, p.102), uma produção em si mesmo de "um modelo gay, que passaria, entre outras coisas, por uma recusa de "bichice" e por uma defesa - ainda que retórica - de certa pretensão de masculinidade".

A quebra de um lugar fixo da "bicha", quer dizer, daquele que faz o papel de passivo no ato sexual, se faz em um contexto no qual ser passivo se associa ao papel feminino. Um papel humilhante, de dominação, subordinação. Uma mulher mal-feita, decerto. E, se a ideia de que a própria mulher já é entendida como um homem mal-feito, o que pensar de uma "bicha"? Uma certa radicalização do mal-feito. Desvio do desvio. Um papel também associado à possibilidade de repressão policial. Nesse contexto, o aumento da tolerância diante de não-homossexuais parece inversamente proporcional ao grau de afetação do indivíduo.

Mudanças. De padrão, de comportamento, de relacionamento, do espaço urbano. Não apenas. Operações policiais que buscavam a limpeza de espaços dominados por travestis, homossexuais e prostituição ocorridas a partir do final da década de 1970 tiveram como efeito, além do reordenamento de espaços frequentados por não-heterossexuais, o acirramento da diferenciação entre gays e os outros não-heterossexuais - sobretudo travestis, bichas; 
pessoas marcadas pela feminilidade. Uma diferenciação passa a ser intensificada. Uma diferenciação entre homossexuais "normais" e os "marginais". Uma diferenciação também de classe social, cindindo os adeptos ao "modelo popular" (mais ligados a figuras afeminadas, como travestis e bichas) e aqueles que preferiam o "modelo normal" (ligado ao recémemergido gay).

Uma cisão social que, como diz Perlongher, "é também uma dissidência enquanto os gêneros sexuais que remete diretamente ao gozo e à "verdade" do sexo"'" (2008, p.116). Cisão marcada pela exclusão e segregação de travestis e uma certa tolerância em relação ao gays, tolerância de fachada, que dizia respeito ao saldo econômico produzido pelo consumismo gay. Afinal, o modelo gay agregava pessoas intelectualizadas e de classe média, com certo poder de compra. Um modelo, então, que permite a geração de lucros, em bares, saunas... Um certo lucro que possibilita algum tipo de tolerância. Assim, uma "modelização gay" que traz consigo uma ampla possibilidade de mercantilização. Para ser aceito, que possa consumir. Essa parece ser a moeda de troca para ser tolerado.

Daí, um modelo que se intensifica como modelo, também por mais tolerável. "Uma espécie "gayzação" das bichinhas e garotos de periferia, que passam rapidamente a imitar os tiques, as roupas e os gestos dos gays de classe media" (PERLONGHER, op. cit. p.118). Jim \& Jim, casal de Beleza Americana, de quem falaremos mais detidamente no próximo item, parecem ser exemplares convictos desse modelo.

Terceira lição: não basta ser e se assumir homossexual. Há de se ser masculinizado, de classe média, intelectualizado, urbano e, de preferência, ter entre vinte e trinta anos. Se não se é, que procure ser. 


\section{4- Quarta Lição: o fim do nomadismo}

Nas escadas do metrô, Harvey troca olhares com Scott. Olhares que se desdobram em poucas palavras e uma noite de sexo. Já Frank, entra calado em um bar localizado em uma viela escura; lá, permanece em silêncio; mais olhares. Jack ao conhecê-lo, o olha; em um bar após um rodeio qualquer, observa o local; em um jantar com a esposa e um casal amigo dela, troca olhares com o homem. Olhares. Pequenos olhares. Quase imperceptíveis. Ou imperceptíveis para alguns.

Imperceptíveis por se tratar de um modo característico de sujeitos envolvidos em transações do meio homossexual, conforme descrito por Perlongher (2008). Uma aproximação que se estabelece "a partir de um jogo de deslocamentos, piscares, olhares, alusões, pequenos gestos quase imperceptíveis para um estranho, através dos quais se trocam sutis sinais de periculosidade, de riqueza e poder, de libidinosidade, de inteligência" (p.68). Uma certa deriva, um descompromisso que pode levar o indivíduo a qualquer lugar. Uma outra forma de aproximação. Uma certa paquera adaptada às “condições históricas de marginalização e clandestinidade dos contatos homossexuais" (p.166).

Como discute Foucault (2000), ao mesmo tempo em que nossa sociedade reprime rigorosamente a homossexualidade, habitualmente os homens desfrutam de um maior grau de liberdade sexual do que as mulheres, já que se acredita que seu desejo sexual seja mais intenso. Nesse sentido, a homossexualidade masculina também se beneficiou de alguma tolerância. Uma intensificação de desejos, ora; se um homem deseja muito, dois desejam muito mais. Uma tolerância desde que as práticas sexuais se limitassem a meros encontros físicos. Algo fortuito. Nada além disso. Um paradoxo assistido ao longo de nossa história, que possibilitou uma inversão: homossexuais, reprimidos em suas práticas, desfrutam de relações 
físicas com uma liberdade maior do que a experimentada por heterossexuais, supostamente livres em suas práticas.

Contrapondo as experiências hétero e homossexuais, Foucault (2000) observa uma importante diferença entre elas: a heterossexualidade, ao menos desde a Idade Média, sempre foi constituída por dois momentos, a corte, na qual o homem seduz a mulher, e o ato sexual em si. O momento de sedução torna-se o momento central no enlace entre homem e mulher. Já na experiência homossexual moderna, a corte tem pouco valor e lugar. Diz o autor que

na cultura cristã ocidental a homossexualidade se viu repelida e teve portanto de concentrar sua energia no próprio ato sexual. Não se permitiu aos homossexuais elaborar um sistema de corte, uma vez que lhes foi negada a expressão cultural necessária a essa elaboração. A piscadela na rua, a repentina decisão de ir logo ao que interessa, a rapidez com que as relações homossexuais são consumadas, todos esses fenômenos têm sua origem numa proibição (FOUCAULT, 2000, pp.30-31).

Proibições, repressões que instauram novas possibilidades de relação entre as pessoas. Uma proibição que reforçou e acelerou a separação entre sexualidade e afetividade, lembra Pollak (1987), da mesma forma que instaurou a possibilidade de cálculos racionais, afinal, "toda vida clandestina exige uma organização que minimize os riscos ao mesmo tempo otimize a eficácia” (p.57). Resultado: o ato sexual destaca-se no tempo e no espaço, restringese ao máximo ritos de preparação (como a corte), dissolve-se a relação imediatamente após o ato e, para que tudo isso corra da melhor forma possível, desenvolve-se um sistema de comunicação próprio. Na clandestinidade, o alvo deve ser bem escolhido e o tiro, certeiro.

Daí, uma nova forma de enlace. Antes e depois. Se, para heterossexuais, "o melhor momento do amor é quando subimos as escadas", para homossexuais, "o melhor momento do amor é quando o amante está indo embora de táxi” (FOUCAULT, 2000, p.31). Algo que indica que a importância nas relações homossexuais é atribuída não à atribuição dos atos, mas, sim, à lembrança deles. Sem tempo para a corte, "a energia passa a ser dedicada à 
intensificação do ato sexual em si, e se desenvolve um novo tipo de práticas sexuais que tentam explorar todas as possibilidades internas da experiência sexual” (p.34). Sexo fácil, então. Sem tempo para a corte, os sujeitos derivam por aí.

Nessa deriva, um deslize entre a multidão. Uma disponibilidade para o novo, para o inesperado, para a aventura, para "acontecer". Mas não qualquer deriva. Uma deriva regrada, na qual eficácia e economia entrarão em jogo na seleção de um possível parceiro. Procura-se pelo maior rendimento, com o menor custo possível. Um cálculo feito já pelo primeiro olhar: de quem olha, para quem olha. Um cálculo que mede o grau de desejabilidade e de periculosidade e risco de recusa do candidato. Olhares distraídos e atentos ao mesmo tempo. Sem tempo a perder, sem jogos, hesitações. Silêncio e anonimato. Características que garantem uma deriva também nômade, de grande mobilidade, pouco sedentária. Deriva marcada pelo acaso, aventura, promiscuidade, relações anônimas e impessoais. Novas conexões possíveis.

Afinal, “os outros não são vistos como "identidades pessoais”, mas apenas como possibilidade de um contato parcial, de órgão a órgão. O corpo é parcelado, certas partes são “separadas” do conjunto" (PERLONGHER, 2008, p.171). A conexão não se dá, assim, com identidades, mas com forças. Mas, a partir do momento em que o que está em jogo são identidades, como fica a conexão entre homossexuais?

Aquilo que Pollak (1987) chamou de coming out parece diferir nos casos de Frank, Ennis e Jack. Um coming out que parece ir além; parece almejar reconhecer desejos e ultrapassar (ou passar muito rapidamente) pelo aprendizado de lugares e modos de encontro, indo quase que diretamente para a estabilização de reclacionamentos.

Ambos os personagens, de alguma forma, buscam a superação dessa situação de deriva. Quer dizer, buscam superar um certo nomadismo, com diversos parceiros, incertezas, anonimato, instabilidade, rotatividade, alcançando uma certa sedentariedade. Buscam fugir às 
supostas faltas trazidas com o nomadismo. Mas esses modos de relação não resultam apenas da impossibilidade de acesso ao paradigma da normalidade - e, assim, à corte, à estabilidade, à publicidade; esses modos de relação dizem respeito também à afirmação de uma recusa fatual:

essas práticas (...) servem de alicerce a verdadeiras redes de sociabilidade "alternativas" a respeito da cultura oficial, "desviantes" ou marginais com relação à norma social dominante, nômades com relação aos módulos de heterossexualidade sedentária (PERLONGHER, 2008, p.194).

São modos de relação onde há um certo afrouxamento do controle. Uma forma também de se opor a valores hegemônicos, que quase sempre exaltam o amor e relações monogâmicas que busquem a reprodução. Da potência afirmativa à falta.

Aí podemos extrair uma grande lição de $O$ segredo de Brokeback Mountain. Jack, de alguma forma, é promíscuo. Deriva por aí. Já que não consegue um relacionamento estável (e assumido) sai à caça de outros homens. E é essa caça que o leva o expõe a perigos. Teria sido ele morto enquanto caçava? Não sabemos e não cabe especularmos. O que importa é que em sua trajetória, somos convidados a pensar que o mercado de intercâmbios sexuais, onde há apenas trocas de orgasmo por orgasmo (POLLAK, 1987), com quase incontáveis parceiros e mais incontáveis relações sexuais; enfim, onde a promiscuidade atravessa as práticas; este seria um mercado a ser tirado da vida das pessoas. A promiscuidade é perigosa; faz mal à saúde. Uma ideia de que, com Ennis, Jack estaria salvo. Quer dizer, se casado, se tranquilamente casado, estavelmente casado, poderia estar salvo. Uma ideia de que um certo tipo de relacionamento, estável, sedentário, entre duas pessoas salva; o casamento salva.

De nômades a sedentários, esta parece ser uma importante transformação operada na construção dessa identidade. E, se para o nômade, a organização se dá pelo bando, pela 
matilha, para o sedentário, a família será a organização paradigmática (PERLONGHER, 2008). Uma situação ensaiada por Harvey e desejada por Frank, Jack, Ennis, Brandon; uma situação concretizada pela dupla Jim e Jim de Beleza Americana.

No filme, vamos conhecer o lado obscuro da família estadunidense, acompanhando a vida de Lecter e Carolyn Burnham, um típico casal de classe média, aparentemente bem sucedidos e felizes. Aparentemente, pois, de perto, suas aparências são desmanteladas, trazendo à tona uma série de práticas, a princípio, pouco convencionais.

De perto, vemos o quanto o casal se odeia e pouco se importam com a filha adolescente. A paixão de Lecter pela melhor amiga de sua filha efetuará uma importante reviravolta em sua vida. Abandona o emprego, resolve malhar para conquistar a garota e deixa de fingir ter um casamento que não tem. Enquanto isso, sua esposa passa a traí-lo. Sua filha cada dia está mais próxima de um garoto vizinho, recém-saído de uma clínica psiquiátrica e traficante de drogas. Na família dele, mais um desmonte: sua mãe tem problemas psiquiátricos e passa os dias embotada; seu pai, um ex-fuzileiro, é homofóbico e agressivo.

Desmonte do American way of life, olhado para além da vitrine. Se na vitrine tudo é harmônico e soberbo, de perto, vemos a luta a qualquer custo pelo sucesso; o culto à beleza e às formas perfeitas; a valorização de um eu individualizado e individualizante, produzido em práticas de auto-ajuda, de disciplinamento militar ou de redenção. De um lado, carros novos, uma casa imponente, com um jardim perfeito; do outro, o tédio, o esvaziamento das relações, o embotamento diante do outro. O sonho do self made man custa caro, muito caro.

Se na vida dos Burnham reina a desordem, não podemos dizer o mesmo de seus vizinhos, Jim e Jim. O casal, que se apresenta como "sócios" à vizinhança, são cordiais, educados, bem vestidos, em forma, estáveis. Criam uma cachorrinha à imagem de uma filha e discutem pela educação dela. Contraposição. A típica família estadunidense se encontra em 
ruínas. Brigas, traições, distanciamento, pura fachada. Se tudo vai mal, não podemos dizer o mesmo em relação ao casal gay da vizinhança. Harmonia, cuidados, diálogo. Uma nova família à vista. Uma mesma família. Como aquela que conhecemos outrora.

Quarta lição: de posse de uma identidade, a estabilidade de si e conjugal deverá ser almejada.

\section{5- Quinta Lição: a forma-família}

Na construção dessa identidade, a sedentarização se torna uma marca presente. Da matilha à família. Uma certa rima paradigmática. Na afirmação de sua possibilidade enquanto família, a descaracterização da família tradicional (de bases heterossexuais, monogâmica, nuclear) como o lócus natural do cuidado e proteção. Parece que é isso que vemos em Preciosa - Uma história de esperança. A trajetória da personagem nos interessa, ajudandonos a entender a construção de uma certa identidade sexual, mesmo que este não seja o foco do filme.

Ambientado no Harlem americano do final da década de 1980, o filme conta a história de Claricee "Preciosa" Jones, uma adolescente de 16 anos, pobre, negra, obesa, analfabeta, portadora do HIV, atendida pela assistência social e expulsa da escola quando é descoberta grávida de seu segundo filho.

Como uma gata borralheira, Preciosa é feita de empregada por sua mãe, que passa o dia todo em casa em frente à $\mathrm{TV}$, além de ser vítima dos mais diversos maus tratos: é agredida física e verbalmente, moralmente rebaixada e ainda abusada sexualmente pela mãe e pelo pai - que as visita ocasionalmente. Em cenas impactantes, assistimos Preciosa sendo estuprada pelo pai e logo descobrimos que ele é o pai de seus dois filhos - a primogênita, Mongo, tem síndrome de Down. 
Ao ser descoberta grávida, Preciosa é expulsa da escola e transferida para uma escola alternativa - a sugestiva "Each One Teach One" - especializada em "alunos problema". Lá conhece Blue Rain, uma professora atenta a cada um de seus alunos. Seu método de ensino: a confecção de diários individuais, onde tudo deverá ser escrito. Pela primeira vez, Preciosa tem amigos e pode participar da aula, começando a ser alfabetizada.

Um divisor de águas na vida de Preciosa. Sorridente, esperançosa, Preciosa sonha em poder cuidar dos filhos e continuar os estudos. Aliás, mesmo no hospital - quando do nascimento de seu filho - Preciosa continua a escrever em seu diário, dialogando com Sra. Rain. Escreve sobre seu dia a dia, de seus sonhos; lê sobre a importância em continuar estudando, para que possa superar as desgraças de sua vida.

Sra. Rain se torna uma importante referência para Preciosa. Professora, faz às vezes de assistente social em busca de um abrigo para Preciosa, quando esta briga com a mãe e sai de casa. Professora, amiga, cuidadora. Tão cuidadora que leva Preciosa e o filho recémnascido para sua casa, onde são acolhidos por ela e sua companheira. Enfim, uma referência imprescindível para as transformações na vida de sua aluna.

$\mathrm{Na}$ trama, falências. A primeira dela, aqui já anunciada, diz respeito à escola, incapaz de ensinar um número cada vez maior de alunos, responsabilizando-os pelo seu fracasso. Em sua primeira escola, Preciosa está jogada às traças, passando desapercebida a maior parte do tempo, com notas altas, apesar de ser completamente analfabeta. Só é lembrada para ser ridicularizada pelos colegas. Exemplo da derrocada escolar em sua função de possibilitar a aquisição de conhecimentos e da capacidade de pensar, produtora de diplomados analfabetos aos borbotões, situação tão próxima de qualquer escola pública brasileira (PATTO, 2005; AQUINO, 2007).

Examinada não apenas em suas destrezas intelectuais, mas, sobretudo, nas vulnerabilidades e riscos que vivencia, Preciosa é transferida de escola. E será em uma escola 
alternativa, onde receberá a atenção individualizada de uma professora-salvadora, que, finalmente, poderá desabrochar, mostrando quem é e quais são suas potencialidades. Mais uma vez a ideia de que o enfrentamento da derrocada escolar pode se dar pela atitude messiânica de professores, comprometidos com a salvação de seu alunado-rebanho. Para isso, uso e abuso de técnicas de auto-ajuda, que primam pelo resgate de uma certa auto-estima perdida nas intempéries da vida. Ao mesmo tempo, a ideia de que Preciosa precisa querer isso. É preciso querer mudar.

Por mais que Preciosa receba ajuda - sobretudo de sua professora -, ela se faz por si mesma. Ou procura se fazer. Assistimos a uma construção subjetiva paulatina, bem à moda do self made man, na qual esperança, perseverança, coragem, superação, autoconfiança são mais do que palavras de ordem. Afinal, diante tantas adversidades, cabe uma suposta escolha em não corromper o caráter.

Aquino (2004) analisa que esta é uma das dimensões para a difusão de valores típicos da sociedade estadunidense. Acrescenta que a relação com o outro é marcada por uma "solidariedade de fachada", que visa a reforma do caráter, a partir da atribuição de culpas, vergonhas, para, enfim, se ter misericórdia. Uma certa luta do bem contra o mal. Seja a relação de Preciosa com sua nova professora, seja com a assistente social, parece que é isso que se busca: uma reforma de seu caráter, uma certa prevenção de tudo aquilo de pernicioso que guarda em si, herança de sua mãe e de sua família desestruturada. Reformada, agraciada: com dinheiro, com possibilidade de ser ensinada, com a ideia de uma nova vida.

Se há uma preocupação com o que Preciosa é hoje, a preocupação com o que ela pode vir a se tornar em um futuro nem tão distante parece maior. Há um certo receio de que ela se torne alguém como sua mãe, tida como indolente, acomodada, violenta. Preocupação que nos faz pensar naquilo que Coimbra (2000), aos moldes de Morel, chamou de "classes perigosas", quer dizer, pessoas que trazem consigo uma espécie de "má herança", portadores 
das "degenerescências", pessoas que "não possuem nem a inteligência do dever, nem o sentimento da moralidade dos atos, e cujo espírito não é suscetível de ser esclarecido ou mesmo consolado por qualquer ideia de ordem religiosa" (MOREL ${ }^{28}$ apud COIMBRA, 2000, p.59).

Há quem carregue consigo maior grau de periculosidade. Riscos diferenciais. Periculosidade que historicamente também esteve associada aos não-heterossexuais. Mas não aqui.

Chama a atenção a maneira como sua mãe lida com o imperativo de reforma de caráter. Ao receber uma assistente social em sua casa, finge. De peruca e com Mongo - a neta que lhe parece um animal - em seu colo, responde tudo aquilo que querem ouvir. Diz estar procurando emprego, cuidando da neta, preocupada com Preciosa. Se a reforma de caráter não se deu, ao menos que se faça parecer que se operou. Oscilante, aproxima-se de Preciosa e logo a agride novamente. Entrevistada pela assistente social, percebe-se examinada em suas entranhas. Recusa tal exame, sendo alvo de repulsa da profissional.

Acrescentaríamos um terceiro meio de divulgar o american way of life: além da relação consigo e com os outros, a relação com o Estado. Afinal, Preciosa deseja deixar de precisar da assistência social, apontada pela Sra. Rain como ineficaz. Ainda, é difundida uma visão pejorativa daqueles que recebem benefícios financeiros do governo, entendidos como preguiçosos, acomodados e preocupados apenas com o dinheiro que irão receber. Ou esta não é uma das imagens difundidas da mãe de Preciosa?

Um outro aspecto do filme chama a atenção: a apresentação da família de Preciosa. O filme joga com a ideia de falência do universo familiar, ao mesmo tempo em que joga com a ideia de fundamentalismo familiar. Ora, mais do que as violências sofridas por Preciosa, o que choca (ou o que se quer chocar) é que essas violências são praticadas por sua mãe e seu

${ }^{28}$ MOREL, B.A. Tratado das degenerescências, 1857. 
pai. Um choque respaldado na ideia de que "família" naturalmente cuida, ou fora feita para cuidar, o que aponta para um modelo de família pautado na necessidade de prole e cuidados dela. Uma família atomizada, composta por uma dupla de adultos cuidadores e filhos. As referências giram em torno dessa ideia de família, de que todos devem ter uma família, essa família, afinal, trata-se de

uma instituição secular que, historicamente, se define pela ligação estrita e íntima entre pessoas que se dispõem a conviver e partilhar suas experiências vitais - com destaque para a guarda e a criação das novas gerações segundo as regras da tradição própria, bem como os usos e costumes típicos de determinado tempo e espaço (SAYÃO \& AQUINO, 2006, pp.9-10).

Ao longo do filme, as famílias são apresentadas como famílias que não dão conta daquilo que as definiria: a convivência entre Preciosa e sua mãe é para lá de tumultuada, as relações de guarda e criação são marcadas por negligências e violências das mais diversas ordens. Da mesma forma, uma vizinha de Preciosa, uma garota de seus dez anos, é atendida pela assistência social com o olho roxo, e a Sra. Rain fala brevemente de uma má relação com sua mãe. Nesse sentido, o enredo parece apontar para uma não naturalidade da instituição familiar, naquilo que se costumou definir.

Nesse aspecto, vale destacar a oposição feita entre a família de bases heterossexuais e a família constituída pelo casal lésbico do filme. Ao mesmo tempo em que joga com a ideia de um "cuidado natural e espontâneo" que inexiste, dizendo que nem todos estão aptos a cuidar de alguém, sobretudo, de um filho, aponta para algo como "deixemos que cuidem aqueles que são capazes". Entre os capazes, muitos casais homossexuais. Capacidade que diz respeito à valorização da educação e cuidado, atributos mais valorizados do que a simples “criação" dos filhos. 
Srta. Rain e sua companheira são descoladas, alegres, requintas, bebem vinho, conversam sobre o dia, falam de amenidades, se preocupam com os cuidados do bebê de Preciosa. Um deslumbre. Pensando em sua mãe e no quanto esta discrimina homossexuais, nos diz Preciosa: "os homossexuais não me violentaram. O que lhe fizeram? Eles não me mantiveram anos a fio numa classe sem aprender nada. Não são eles que vendem crack às pessoas no Harlem (...) Foi a Srta. Rain que pôs o giz na minha mão. Ela me fez a rainha do abecedário". Uma constatação: os homossexuais, não apenas deixam de apresentar um certo perigo (mesmo que virtual), como se tornam uma alternativa à corrupção das relações interpessoais. São bons. Honestos. Cuidadores. Sobretudo quando se põem em família. De malvados em potencial, a boas pessoas.

Saudades da família. De uma família que estava habituada a cuidar. Pelo menos em tese. Em um momento em que cada vez mais se enfatiza a função protetiva da família, aquilo que seria sua função básica deixa de acontecer, ao menos nas famílias tradicionais. Momento também em que assistimos cada vez mais a presença de arranjos do tipo "não-famílias", como pessoas solteiras, que moram sozinhas. O que poderia ser entendido, segundo Pollak (1987), como o desejo em experimentar estilos de vida nos quais sejam combinadas relações sexuais transitórias e uma vida sexual e afetiva baseada em uma multiplicidade de relações, passa a ser vivido como uma falta. Falta de companhia, de estabilidade... Ao mesmo tempo, parece faltar famílias no mercado e, entre as que têm, não necessariamente exercem suas funções.

Se falta na prática, as concepções que dão o lastro para sua importância permanecem pouco ameaçadas. Weeks (2007) aponta que o casamento, característica-chave da heterossexualidade institucionalizada, permanece em alta. Casando-se ou não, permanece hegemônica a crença de que a intimidade doméstica, alcançada no e pelo casamento e a constituição de uma família, é fundamental como base para a vida social. Há, assim, toda uma 
manutenção da ideia de casamento e família; manutenção e alargamento dessa ideia, com, por exemplo, a inclusão de novos arranjos sob tal égide.

Casa-se e se constitui família. Não qualquer família. Apesar de novas composições também serem considerados oficialmente como tais, na experiência cotidiana não é bem assim. Mesmo morando juntos, compartilhando a vida, vários são os casais que não se vêem como uma família, apontando para uma certa falta, como discute Paiva (2007). Falta por a família da concretude nem sempre conseguir se adequar às devidas exigências tidas como definidoras de uma família tradicional. A começar pela presença de um homem e de uma mulher.

De qualquer forma, a quinta lição: casais homossexuais são boas famílias em potencial. E podem ocupar um lugar que vem sendo deixado por heterossexuais.

\section{6- Muitas e tantas lições}

Nos filmes aqui analisados, uma semelhança: personagens não-heterossexuais apresentados como pessoas quaisquer, com seus trabalhos, amores, medos, dramas, esperanças, possibilidades... Gente como a gente, praticamente. Sob a premissa de possibilitar a legitimidade de certos desejos, uma nova imagem desses personagens. Basta de estereótipos e tratamentos pejorativos, como aqueles identificados por Moreno (2002), mesmo que eles também digam da realidade de vida de muitas pessoas. Uma nova maneira de apresentar homossexuais ao público. É preciso, por exemplo, para um jovem se reconhecer como homossexual, como lembra Louro (1997), que ele deixe de perceber gays e lésbicas como desvios, patologias, formas não-naturais e ilegais de sexualidade. 
Isso parece se dar nos filmes em questão. Parece haver uma ruptura com o tratamento pejorativo e desqualificador, costumeiro ao se falar de personagens homossexuais no cinema. Um avanço, então?

Pollak (1987), discutindo como a homossexualidade passou a habitar um campo de visibilidade e dizibilidade, entende que, com a retirada pela Associação Psiquiátrica Americana (APA) da homossexualidade do rol de perturbações mentais, ocorrida em 1974, além de uma reviravolta nas relações de forças de então, se deu um favorecimento à naturalização do fenômeno homossexual. Uma armadilha, que leva a duas possibilidades de entendimento. Em primeiro lugar, entende-se que a homossexualidade, naturalizada, em nada difere da heterossexualidade, exceto por sua escolha de objeto; em segundo, o entendimento de que a natureza homossexual seria completamente diferente, constituindo uma espécie de "terceiro sexo".

Ambas, carregariam esse caráter naturalizado, no qual, então, aquilo que é da ordem social se torna biológico, e o que diz respeito a questões coletivas se torna questões individuais. Quer dizer, torna-se a homossexualidade algo a-histórico, algo que supostamente sempre teria existido. Parece que é isso que acontece nos filmes em questão. Frank, Ennis, Jack, Harvey, Brendon, Jim \& Jim, Srta. Rain, todos estavam ali, como se sempre tivessem estado. Dito de outra maneira, suas existências ultrapassam o tempo e o espaço, podendo serem transpostos para décadas outras, sem grandes sustos causados com suas presenças. São personagens parecidos, com questões parecidas - a discriminação, o preconceito, o enfrentamento da violência, o desejo por um amor, o desejo em cuidar daquele que se quer bem...

Bem, a mudança na apresentação de personagens homossexuais, agora naturalizados, tem seus custos. Não ser mais estereotipado e não fomentar preconceitos e exclusões de maneira alguma é o único efeito nessa mudança. 
Sedgwick (2007) aponta o outro lado dessa moeda: ao mesmo tempo em que uma definição (positiva) é capaz de organizar e descrever experiências, dando sentidos a existências, ela é indispensável para aqueles que se definem contra ela. Dizer-se, então, homossexual, significa também dar armas àqueles que se quer combater. Swain (1999, p. 118), é enfática quanto essa questão: “a criação de corpos sexuados, a instalação de diferenças e de espaços de exclusão afirmam uma normalidade que apaga o múltiplo e naturaliza o binário”. Quer dizer, de alguma forma, mesmo não se querendo, afirmar-se homossexual viria junto de uma reafirmação da relação normal-anormal.

Assumir-se a partir dos nomes dados às práticas consideradas desviantes tem um efeito muitas vezes negligenciado: a (re)legitimação da norma que criara as zonas de exclusão. Afinal, “uma definição já é uma delimitação, é cercar um espaço que logo dará origem a novas exclusões" ${ }^{29}$. Buscam-se definições, mas a pergunta central deixa de ser feita: o que tornam necessárias definições a nosso respeito? Quer dizer, definições que nos colocam em devidos lugares, que fixam, que paralisam, que pouco falam de nossas possibilidades de vir a ser, de não estarmos mais nesses lugares que ocupamos e virmos a ocupar outros. A questão, então, não se trata da busca de si e sim da busca que se empreende, que dificilmente diz respeito a uma busca em si, não de si, mas de potências desejantes.

Referindo-se à identidade lésbica, Swain (1999), lembra que a visibilidade, a partir da qual maneiras outras de se vestir, de ser, agir, de destacar uma singularidade,

"não fazem senão internalizar a ordem binária na medida que expõe uma diferença e a diferença supõe um modelo. Assim, na questão espinhosa de "sair do armário", de "ser ou não ser" não se coloca que se a heterossexualidade é obrigatória e que a homoliga sexo/gênero, sexualidade/desejo define a normalidade em sua exata correspondência” (p.117).

${ }^{29}$ SWAIN, op. cit., pp.118-119. 
Definitivamente, não se pode querer que novos Brandons e Jacks sejam assassinados ou que pessoas sejam consideradas doentes como Frank nem presas como conhecidos de Harvey. Na busca por uma certa igualdade, a polaridade entre homossexualidade e heterossexualidade parece se manter. Talvez até ganhe forças. Afinal, pouco se questiona sobre a produção dessa polaridade, o que a tornou concebível e necessária no mundo em que vivemos. Discute-se, de um modo geral, que a manutenção dessas desigualdades não deve permanecer. Não se questionando a produção dessas desigualdades, direitos e diferenças sexuais permanecem sendo concebidos em relação à heterossexualidade. E a defesa de um discurso que propõe a valorização e mesmo exaltação às diferenças - o "Viva a diferença!" parece implicar, diz Louro (1997), uma conformação ao status quo das relações sociais, como se as aceitasse tal como se dão costumeiramente. Valorizar as diferenças sem se por em questão o contexto no qual elas são produzidas, significa, de alguma forma, referendar tal contexto, aceitando que as coisas são do jeito que são.

De qualquer forma, os filmes trabalham com novas imagens a respeito dos homossexuais. Trabalhadores, respeitáveis, buscam a felicidade. No amor, no estabelecimento de relacionamentos estáveis, na constituição de casamentos e famílias, no oferecimento de cuidados. A diferença? A falta de oportunidades do mundo em que vivem; suas práticas e desejos sexuais são meros detalhes. Questão de desigualdades, então. Se práticas sexuais parecem, assim, não destacar nenhum deles em seus atributos, paradoxalmente, defende-se a afirmação de uma identidade. Uma identidade construída a partir da sexualidade. Paradoxo. Reconhecer-se em sua diferença para que esta se torne indiferença.

Como aponta Perlongher (2008), para compreendermos a construção dessa identidade homossexual, devemos nos lembrar que ela se dá na perspectiva do chamado “modelo igualitário". Assim, 
sua instauração não implicaria somente um desvelamento das paixões "reprimidas" e condenadas à penumbra ao longo dos séculos (clandestinidade que imprime sua marca em muitas das práticas atuais, como no mecanismo do trottoir), mas suporia uma espécie de tradução, como se antigas paixões pudessem, graças à versatilidade fundamental do desejo humano, ser vertidas em novos moldes. Operativo de "modernização" que, após, certo estágio de festividade difusa, rapidamente recuperado pelo consumismo das modas e a indústria do lazer, parece proceder a uma redistribuição dos enlaces homoeróticos, reagrupando seus cultores nas novas casinhas da identidade e, o que é mais grave, condenando os praticantes das velhas modalidades, as "homossexualidades populares", a uma crescente marginalização que pode conduzir a um recrudescimento da intolerância popular a respeito da nova homossexualidade "branqueada", beneficiária da tolerância burguesa (PERLONGHER, 2008, p.202).

Parece importar menos a suposta interioridade pré-existente do que aquilo que pode ser feito com ela. Descobrir a si mesmo é fundamental, por oferecer uma cara matéria-prima a ser utilizada na construção de identidades. Bem, com a construção de uma identidade homossexual, assiste-se a uma certa reterritorialização, na qual o sujeito passa a se guiar por outros códigos instrumentais, por outras normas. Quer dizer, ocupa territórios de maneiras outras, o que traz efeitos no modo de se relacionar consigo, com os outros, com o mundo. Uma reinserção em códigos que não é meramente simbólica; uma reinserção literal, concreta, com a "produção de marcas no corpo, tipificação da indumentária, modelizações de tiques e trejeitos, serialização de moldes gestuais e sexuais, seleção e valorização do parceiro sexual, etc.” (PERLONGHER, 2008, p.192).

Novos corpos são produzidos, então. Corpos e almas. É disso que falamos ao nos referirmos à construção de uma identidade homossexual.

Butler (2007), referindo-se a Foucault, lembra que o sexo é uma categoria, por definição, normativa. Partindo de uma prática regulatória, produz os corpos que governa. Quer dizer, produz aquilo que se apresenta com ares de naturalidade: mulheres, homens, 
heterossexuais, homossexuais... Diz respeito a um ideal regulatório que vai se materializando através do tempo. Dito de outra maneira, o sexo refere-se a discursos que possuem efeitos físicos, concretos, que tratam da maneira como as pessoas existem. Uma concretude. Concretude que se faz enquanto efeito do poder. Efeitos. Efeitos que tornam alguém viável, possível, inteligível. Ou inviável, impossível, ininteligível.

Nesse sentido, podemos entender o sexo como um ideal cujas normas regulatórias "trabalham de uma forma performativa para construir a materialidade dos corpos e, mais especificamente, para materializar o sexo do corpo, para materializar a diferença sexual a serviço da consolidação do imperativo heterossexual” (BUTLER, 2007, p.154). Processos de materialização que buscam se estabilizar para produzir efeitos de fronteira; efeitos de fixidez, de superfície. Fronteira de matérias. Matérias que se materializam tendo em vista efeitos produtivos.

Nessa materialização, uma tendência à biologização dos corpos. Tomadas pelo discurso psiquiátrico do século XIX, fronteiras entre o que se convencionou chamar de homossexualidade foram traçadas em relação à tal da heterossexualidade. Uma fronteira que dizia respeito à definição entre o normal e o anormal, que circunscrevia o que era perverso. Momento em que a preocupação com o sexo se mostrava generalizada, como nos mostrou Foucault (1988). Uma certa "pan-sexualidade" rondava, conclui Ariès (1987), já que a sexualidade começa a deixar de ter um campo próprio, invadindo o corpo dos indivíduos e todo o espaço social. Uma preocupação generalizada que destaca certas sexualidades, sobretudo as ditas "anormais".

Tomando de empréstimo a concepção clerical da homossexualidade, a medicina, segundo Ariès tornou-a uma doença, uma enfermidade a ser diagnosticada e tratada. Antes, um pecado contra a alma, agora, uma aberração psíquica. Em ambas, culpa e vergonha. Daí a necessidade em se identificar características e o que havia de homogêneo nessa "espécie" - os 
homossexuais - que emergia. Nesse contexto, sair da clandestinidade, tornar-se visível, significava "retornar ao mundo marginal da perversão onde havia vegetado, até que a medicina de lá o tirasse, no século XVIII, para seu museu de horrores e de moléstias contagiosas" (ARIÈS, 1987, p.82).

Traçando parte da história da homossexualidade, Weeks (2007) identifica que as transformações na vida familiar ocorridas a partir do século XVIII, associadas às marcadas distinções de papeis sociais e sexuais masculinos e femininos "tiveram o efeito de aumentar a estigmatização dos homens que não se conformassem prontamente aos papeis sociais e sexuais deles esperados" (p.67). A homossexualidade, assim, refere-se a uma invenção que falava de uma tentativa de regular e controlar aquilo que era considerado a perversidade sexual, trazendo consigo a ideia de uma natureza própria, distintiva. Buscam-se essências. Quer dizer, inventam-se essências, que logo deverão ser buscadas. Corpos subtraídos do campo social, pois. E do tempo, do espaço, da história.

Quando se refere à performatividade do sexo, Butler (2007) a entende como práticas reiterativas e citacionais pelas quais o discurso produz os efeitos que ele nomeia. Uma reiteração normativa. Isto é, a repetição de algo. Algo que é produzido acaba envolto por ares de naturalidade, de pré-existência, simplesmente por tanto se repetir. Como uma mentira, que de tanto contada, se tornou verdade. Nesse sentido, as próprias diferenças sexuais podem ser entendidas já como efeito do poder, de um poder que visa distinguir, categorizar, para, enfim, gerir, controlar. Ser mulher, homem, heterossexual, homossexual: não há nada de natural nisso. O que há são efeitos de poder. Tudo isso já é efeito. Efeito de naturalidade, de préexistência. Um efeito que materializa corpos, sentimentos, desejos, comportamentos, identificações. Um efeito que, por fim, materializa um sujeito.

A partir de uma matriz excludente - pela qual apenas certas identificações sexuadas são possibilitadas - produzem-se, ao mesmo tempo, seres abjetos, isto é, seres que inabitam a 
vida social, seres que não são "sujeitos", que não gozam desse status. Seres que, por isso, terão de reivindicar o direito à autonomia e à vida. Formas marginais de existência, formas estas, que deverão ser negadas, com as quais não se deve ter qualquer identificação, caso queiramos uma existência possível (BUTLER, 2007). Sujeitos que "não são", nas palavras de Louro (1997), por não poderem ser associados aos atributos desejados, seja por não poder existir ou por não poder ser nomeado. E algo que existe não existindo pode ser facilmente eliminado. Ou ao menos essa pode ser uma pretensão. Mais do que respondermos que formas são essas - e, assim, confirmarmos aquilo que, de alguma forma já sabemos: não-brancos, não-heterossexuais, não-ocidentais, não-urbanos, não-burgueses, e assim por diante, constituem os considerados excluídos, dominados, ou qualquer denominação semelhante -, que perguntemos que formas abjetas vêm sendo (re)produzidas pelo cinema contemporâneo?

Nos filmes, uma incitação a se nomear. Não se nomear adequadamente tem um alto preço, como o pago por Brandon, em Meninos não choram. Buscas por adjetivos, substancializados. Adjetivos que se transformam em substantivos. Que substantivam. Que produzem sujeitos. “A nomeação, diz Butler (2007, p.161), é, ao mesmo tempo, o estabelecimento de uma fronteira e também a inculcação repetida de uma norma". E que fronteiras vêm sendo estabelecidas?

A primeira delas, talvez, a fronteira entre a homossexualidade e a heterossexualidade. Fronteira que serve a diversas distinções. Físicas, psíquicas, comportamentais, relacionais, de aptidões, de direitos. Uma atração por pessoas do mesmo sexo ganha um nome, uma categoria pela qual as pessoas devem se definir. Uma fronteira que reclama a distinção entre normal e anormal.

Fronteiras também dentro da própria delimitação de homossexualidade. Uma repartição desse campo, com áreas mais ou menos possíveis de existir. Assim, fronteiras entre gestos permitidos, jeitos de se olhar, de se falar, de se preferir. Fronteiras entre os sentidos 
permitidos, autorizados. Os filmes não apenas expressam modos de vida, eles os instituem, procuram fixá-los. Desejar pessoas do mesmo sexo? Pode. Desde que se sigam algumas regras. Que se deseje homens masculinizados, assumidos. E que os deseje de forma estável. Um por vez e pelo maior tempo possível. Que se deseje de forma não promíscua, fiel, honesta, limpa. Que se deseje quase como um heterossexual.

Parece haver nos filmes um desejo de sair da marginalidade. Estar à margem parece significar unicamente não ter sua existência e direitos reconhecidos. Parece ter de fugir com seu amor, como Frank o fez; parece se desencontrar por uma vida toda; como Jack e Ennis; parece não poder ser professor, contra o qual lutou Harvey; parece ser morto, como Brandon. A luta passa a ser contra os efeitos, contra os efeitos de marginalidade, não contra a produção de marginalidades. Um puxão de rédeas na luta, diria Ariès (1987). Parece que a luta travada resume-se ao aumento da tolerância, da aceitação, em bares, hotéis, na rua. E o aumento dessa tolerância seria proveniente de "uma mudança de representação dos sexos, não apenas de suas funções, de seus papeis a nível profissional e familiar, mas de suas imagens simbólicas" (p.80). Daí, a produção de um novo homossexual.

Logo, um discurso que incita a construção de uma identidade estável, fixa, autêntica, tendentemente universal (mas com ares particulares). Descoberta ou construída, o ponto de chegada será o mesmo: um novo bloco monolítico a ser duramente alcançado pelos sujeitos. Algo da ordem do privado, que, posto nestes termos, deixa de ter a ver com uma construção que se faz necessariamente no coletivo, no social. A identidade, assim, se torna um problema de cada um, uma tarefa com a qual se haverá durante a vida.

Se não se nasce homossexual, mas se torna, se aprende a ser, como diz Pollak (1987, p.61), "raros são os que conseguem se libertar da socialização a que foram submetidos na influência, socialização exclusivamente orientada para uma vida heterossexual”. O autor identifica uma certa esquizofrenia na gestão da vida, já que o hábito homossexual, que guia as 
maneiras de viver, "resulta da socialização anterior ao coming out e do grau de interiorização das regras do meio" (p.61). A tarefa na construção de uma identidade homossexual, assim, tratará de (des)conciliar as regras aprendidas desde a mais tenra infância - relacionadas a ser heterossexual - e as novas regras, relacionadas ao mundo homossexual.

Nessa (des)conciliação, desencontros. Dificilmente a regra de um se aplica ao outro. Desencontros produtores de intensos sofrimentos, sobretudo ligados à cisão entre afetividade e sexualidade, “cisão que resulta da falta desse cimento social e material que tende a fazer durar os relacionamentos heterossexuais" (p.65). Sofrimento que fala de uma falta produzida, superimposta pela norma heterossexual. Quer dizer, uma norma que incide sobre indivíduos e casais homossexuais, que, sem um modelo próprio de vida, buscam parâmetros outros, muitas vezes pouco adequados a sua realidade. Uma falta que fala de um ideal sentimental, hegemônico entre relacionamentos heterossexuais e que passa a se expandir também para relacionamentos de outras ordens.

Ariès (1987) entende que a afetividade não se encontra ausente da relação sexual homossexual. Diferentemente da relação heterossexual, a afetividade fica reportada para após o ato sexual e configura um momento breve. Dura um instante, "na intensidade do instante não-renovável, uma intensidade pouco compatível, parece, com a ternura, com o sentimento" (ARIÈS, 1987, p.86). O que se tem, então, é uma outra possibilidade de conectar afetividade e sexualidade, correspondendo a outras sensibilidades possíveis. Mas uma outra possibilidade que acaba vivida como falta, uma disparidade entre aquilo que se aprendeu por uma vida e aquilo com o qual se depara na concretude cotidiana. Esquizofrenia.

Esquizofrenia a ser facilmente contornada com a promoção de socializações do tipo daquela orientada exclusivamente para uma vida heterossexual, agora diretamente para os homossexuais. Sim, uma espécie de heterossexualização da socialização e, assim, da gestão da vida. 
Controle, gerenciamento de corpos e da população. Esses parecem os mais evidentes efeitos do transbordamento da sexualidade para todo o campo social. Ariès apresenta um outro efeito, um tanto quanto curioso. Entende que a sexualidade, até meados do século XVIII, estava contida no interior ou da procriação ou da perversidade, sendo, respectivamente, legitimada ou condenada; fora desses limites, o espaço estaria livre para o sentimento, para a afetividade. O que acontece é que, sistematicamente, o sentimento passou a ser captado pela família, que o vai monopolizando. Antes, a amizade era um importante espaço para o sentimento, mas como, desde o século XIX vem se intensificando seu declínio (ao menos quando falamos da amizade entre adultos), a afetividade, os sentimentos passam a ser associados à sexualidade. Afetividade passa a ser algo de casados, já que somente a sexualidade ligadas à procriação era permitida. "O objetivo era fazer do homem o homem-pai, cidadão ocupado exclusivamente em trabalhar, cuidar dos filhos e fiscalizar a moral sexual das esposas", lembra Costa (1992, p.34), apontando que tais exigências eram incompatíveis com as experiências homoeróticas ligadas à afetividade que perpassavam redes de camaradagem, exclusivamente masculinas. Uma forma de melhor gerir aquilo que acontecia em círculos restritos, nos quais pouco se sabia o que acontecia. Pescarias, acampamentos, passeios a cavalos, bares... atividades restritas a homens e de difícil controle.

Nesse contexto, a sensação de falta derivada da separação entre sexualidade e afetividade vivenciada por muitos homossexuais era absolutamente prevista, normal, há alguns séculos. Fazia parte de algo dentro da normalidade. Invenção recente esta, que, para Ariès, se relaciona com a extensão de um campo de uma homossexualidade que possui normas específicas. Esta homossexualidade, então, viria junto com o declínio da amizade.

Aquilo que era vivido como uma ambiguidade, uma indecisão, uma "amizade particular", vai ganhando contornos da homossexualidade. Diz o autor: 
Penso que é a partir de uma sexualidade aparentemente assexuada, que se enraíza, em determinadas culturas (Quattocento italiano, Inglaterra elizabetana), uma forma de amor viril nos limites da homossexualidade, mas de uma homossexualidade que não se confessa nem se reconhece, que deixa subsistir o equívoco, menos por receio das proibições que por repugnância em se classificar num dos dois compartimentos da sociedade da época: o não-sexual ou o sexual. Ficava-se numa zona mista, que não pertencia inteiramente nem a um nem a outro (ARIÈS, 1987, p.87-88).

Nesse contexto, uma nova forma-família, agora também entre os homossexuais, que buscam superar a cisão entre afetividade e sexualidade. A "família homossexual ampliada", composta por um círculo de antigos amantes que se tornaram amigos, passa a conviver (e talvez a dar lugar) a uma família de bases heterossexuais, composta por um casal monogâmico e filhos. Filhos que podem ser animais de estimação, desde que tratados como tais, como a cachorrinha de Jim \& Jim.

Falamos, assim, da perpetuação de um modelo outrora contestado e que já se encontra em plena mutação. Uma perpetuação que se refere a um grande desejo de normatividade e uma possível supressão da diferença sexual, como defende Roudinesco (2003). Esse desejo por família, diz ela, tem a ver com um desejo de gerar e de transmitir uma história. Desejo forjado em um momento no qual toda uma geração de homossexuais foi dizimada pela AIDS. Daí, uma busca por se adaptar à estrutura familiar que essas pessoas conheciam, uma estrutura "desconstruída, medicalizada, esfacelada, periciada" (ROUDINESCO, 2003, p.196).

Constituir família e criar filhos assume também uma posição de contraargumentação diante de idéias de perversão e imoralidade. Uma prova de que gays e lésbicas poderiam ser bons pais tanto quanto - ou mais - que famílias heterossexuais. Para isso, a criação de um campo indiscriminado entre diferentes famílias. Pais homossexuais e pais heterossexuais tornam-se pais apenas. Ou pais homossexuais adentram às normas da 
paternidade heterossexual, provando o quão bons e cuidadosos podem ser e procurando garantir não criar novos homossexuais. Mas

\begin{abstract}
"Será preciso admitir um dia que os filhos de pais homossexuais carregam, como outros, mas muito mais que os outros, o traço singular de um destino difícil. E será preciso admitir também que os pais homossexuais são diferentes dos outros pais. Eis porque nossa sociedade deve aceitar que eles existem tais como são. Ela deve lhe conceder os mesmos direitos. E não é obrigando-se a serem "normais" que os homossexuais conseguirão provar sua aptidão a criar seus filhos" (ROUDINESCO, 2003, p.195).
\end{abstract}

A AIDS, aponta Perlongher (1991), tem outros efeitos sobre a homossexualidade. Com ela, uma radicalização no refluxo da revolução sexual antes operada. Uma intensificação no processo de medicalização da vida social, que associa cada vez mais o sexo à morte. Acontece, assim, “outra volta do parafuso do próprio dispositivo de sexualidade, não no sentido de castidade, mas no sentido de recomendar, através do progressismo médico, a prática de uma sexualidade limpa, sem riscos, desinfetada e transparente" (p.42). Mais uma deixa para a valorização de um amor romântico, que associa sexualidade e afetividade, dentro das fronteiras da vida conjugal.

Podemos pensar, então, numa aproximação crescente entre a homossexualidade e a heterossexualidade. O resultado: uma homossexualidade masculinizada, viril, não-promíscua, de família, legalista e legalizada. Uma homossexualidade de valores heterossexuais. Saída da margem, da marginalidade, se torna autônoma, perseverante, autoconfiante. Bem à moda do self made men. Afinal, deixar a margem significa compartilhar esses valores. Vemos, assim, um processo de higienização, algo semelhante ao acontecido com Preciosa, saída das raias da exclusão para um local onde poderia ser melhor gerenciada. 
Nesse processo de higienização, marginaliza-se cada vez mais aqueles que não se adéquam às definições homossexuais em voga. Travestis, "bichas loucas", os "modelos populares", a promiscuidade, os relacionamentos passageiros, isso tudo parece ficar fora da fronteira traçada. Fronteiras que são efeitos de poder. Entendendo o poder como uma ação sobre uma ação, sobre que ação se tem atuado? Que força se tem buscado neutralizar, aniquilar? Que formas de existência, então, são excluídas e apagadas?

Foucault (2000) acredita que o que mais perturba quem não é gay é a forma de vida gay. O que incomoda tem pouco a ver com se assumir publicamente, acariciando-se e vestindo de outras maneiras, nem seus atos sexuais. O que incomoda diz respeito ao

temor geral de que os gays desenvolvam relações intensas e satisfatórias apesar de não se ajustarem à ideia que os outros têm do que sejam essas relações. O que muitas pessoas são incapazes de tolerar é a possibilidade de que os gays sejam capazes de criar tipos de relações não previstas até agora (p.40).

Incomodam novas relações, novas formas de se relacionar, com normas mais flexíveis, menos institucionalizadas. É isso que incomoda. A sexualidade burguesa, diz Costa (1992), não podia (e não pode) admitir um erotismo fluido, ambíguo, indiferenciado, rebelde. Assim, era preciso "mostrar que os limites do gozo estavam seguramente inscritos na ordem do parentesco e na fronteira da morte, mas também nos interesses da raça; das classes; das nações; dos Estados; das metrópoles e impérios" (COSTA, 1992, p.43), enfim, em seus próprios interesses.

Incômodo a ser combatido com a ideia de que podem (e talvez devam) estabelecer relações mais heterossexualizadas. Ou mesmo relações homossexualizadas. Um passo atrás.

Costa (op. cit.), ao falar da metamorfose do homoerotismo em homossexualismo, aponta que o rótulo de homossexualidade, criado no século XIX, sempre se mostrou largamente insuficiente para descrever a diversidade de experiências dos sujeitos com 
inclinações homoeróticas, da mesma forma que a heterossexualidade procura designar fatos absurdamente disparatados. A homossexualidade estaria associada à captura de experiências homoeróticas - “experiências orientadas por finalidades ético-estéticas, que visam construir domínios eróticos, onde os prazeres proibidos ou permitidos não obedecem à codificação moral criada pela ciência” (COSTA, 1992, p.43). Uma modulação a essas experiências, múltiplas, incontáveis, que cria regras, funcionamentos, repetições, parâmetros... Um aprisionamento de potenciais, na verdade. Nesse sentido, produzir homossexuais já significa uma tentativa em controlar, gerir aquilo que incomoda. Já significa produzirmos sujeitos normativos, afinal, qualquer que seja a identidade, ela trata de um momento, de algo relativo, localizado político-culturalmente, que responde a certas necessidades.

Se a identidade se trata de um momento, parece que não é isso que assistimos nos filmes escolhidos. Ao longo do tempo, características comuns. Desejo em viver a sexualidade mais publicamente; desejo por relacionamentos estáveis; desejo por uma felicidade associada à visibilidade e ao casamento. Parece ter sido sempre assim. O avanço de Jim \& Jim, um casal que mora junto, em um relacionamento estável, quase completamente visível (já que eles se apresentam como "sócios") parece pouco se comparado à vida dos outros personagens. Nos anos 90, Brandon buscava estabelecer-se com Lana. Em plena década de 80, Sra. Rain já era casada e se mostrava apta a ter filhos. Na década de 70, Harvey teve relacionamentos estáveis e públicos. Na década de 60, Jack e Ennis lutavam para conseguir manter o relacionamento. Na década de 50, Frank abandona a família e vai viver com seu amado. Uma só história. Passado e presente tornam-se um só.

O preço da estratégia de glorificação do passado será o reforço da ideia de que o "homossexual" representa uma espécie de povo, etnia, agrupamento político ou seita religiosa, com seus momentos de apogeu, declínio, opressão e liberação. Como consequência, pede-se, implicitamente, a todos os indivíduos com inclinações homoeróticas que aceitem pertencer a esta comunidade de tradição, aceitando um só 
passado, uma só herança cultural e, por fim, uma só identidade de desejos e aspirações (COSTA, 1992, p.50).

Parece que é isso o que acontece quando colocamos lado a lado os filmes em questão. Desejos e aspirações são acachapados. Essa parece uma das mais importantes lições: os desejos e aspirações daqueles com inclinações homoeróticas - transformados em homossexuais - são os mesmos ao longo do tempo e, se assim o são nas telas, que o sejam fora delas. Uma operação meticulosa, invisível, sorrateira. O que está em jogo, dessa forma, é a gestão de desejos e aspirações dessas pessoas. Para uma melhor gestão, seu nivelamento, a produção de desejos e aspirações niveladas. Deseja e aspira-se o mesmo. O mesmo que fora estabelecido outrora pela norma.

Nesse sentido, evocamos um questionamento de Bourdieu (2010), que, de tamanha precisão, o reproduzimos na íntegra:

Como se revoltar contra uma categorização socialmente imposta organizando-se como uma categoria construída segundo esta categorização e fazendo assim existirem as classificações e as restrições às quais se pretende resistir - em vez de, por exemplo, lutar por uma nova ordem sexual em que a distinção entre os diferentes estatutos sociais fossem indiferentes? (p.145).

Homossexual, gay, lésbica... qualquer uma dessas categorias parecem pouco se distinguir. Ambas falam de construções sociais; uma pura ficção, todas inventadas em uma ordem heteronormativa. Não basta, assim, atacar a representação dessas pessoas, procurando uma suposta representação mais próxima de uma suposta realidade. Sem colocar em xeque as próprias categorias a que se quer melhor representar, giramos em falso. Um suposto avanço apenas. 
Avanço por garantir a visibilidade das pessoas, avanço pela garantia de direitos. Garantia de "existência". De reconhecimento. Mas o reconhecimento de sua sexualidade, dessa particularidade, implica sua anulação, como se os homossexuais, "que tiveram de lutar para passar da invisibilidade para a visibilidade, para deixarem de ser excluídos e invizibilizados, visassem a voltar a ser invisíveis, e de certo modo neutros e neutralizados, pela submissão à norma dominante" (BOURDIEU, 2010, p.146). Afirmarem-se bons cônjuges, bons pai, bons trabalhadores, "pessoas comuns", assim, assume ares de retorno à norma, à mesma norma que produziu tais categorizações e desigualdades.

Acabada a orgia homossexual. Acabada a revolução sexual. Perlongher (1991) é incisivo quanto a esta questão. Para ele, a homossexualidade contemporânea comemora a sua morte. A morte da potência intespestiva. Ao menos da homossexualidade masculina. Diluída na vida social, a homossexualidade, na maior parte do tempo, pouco chama a atenção. "Uma intriga a mais. (...) Um sentimento nada especial, como algo que pode lhe acontecer a qualquer um” (p.43). Uma banalidade. Não por ter sido, enfim, completamente repreendida. Uma morte endógena, vinda de dentro. Justamente com o reconhecimento do direito à diferença sexual. Uma intensa produção de desinteresse; a homossexualidade vai se tornando desinteressante, aborrecida. Uma coisa qualquer. Anestesiante. Limpa, medicalizada, desinfetada.

Na luta por direitos, a letra morta da lei. Pela defesa da visibilidade, da união civil, do direito à herança, à adoção, ao plano de saúde, ao imposto de renda. Bandeiras que não necessariamente aproximam a vida daquilo que ela pode. Bandeiras que não necessariamente falam da expansão da vida. 
PARTE V-CORTA 


\section{6- Por FIM...}

Algo acontece quando assistimos um filme. Somos interpelados por imagens, por sons, por idéias, concepções. Fluxos que traçam fronteiras. De quem somos, do que somos. Do que desejamos, de quem desejamos ser. Lições sutis, discretas e de um intenso potencial, justamente por pouco falar de seu caráter educativo. Um jogo de produção de verdades; uma técnica utilizada também para compreendermos quem somos.

No tocante às diferenças sexuais, um paradoxo. Uma mudança significativa no retrato (e produção) de homossexuais. Antes o cinema parecia ensinar um modo de ser homossexual sobretudo de forma estereotipada e desqualificada, fomentando concepções e práticas de exclusão. A experiência homoerótica que se traduzia na qualificação dos sujeitos sobretudo como "bichas loucas" vai dando lugar a novas qualificações. Esses sujeitos passaram a ser progressivamente vistos como pessoas quaisquer, com certa dignidade e a necessidade de direitos a serem garantidos. Uma mudança de valor do negativo para o positivo. Uma inversão, considera Rolnik (1996, p.121) que, "além de manter tais personagens no mesmo lugar, às vezes até os reforça em seu modo de subjetivação identitário". Criação de uma redundância, considera Costa (1992): a inclinação homoerótica passa a ser resumida como homossexualidade. E uma divisão natural se instaura: heterossexualidade de um lado, homossexualidade de outro.

No enredo que criamos, um certo apaziguamento. Do potencial disruptivo de sexualidades marginais. Das possibilidades de invenção de maneiras outras de agenciar afetos, de se conectar com outras pessoas. Da possibilidade de diferenciação, a reafirmação do mesmo. Mais do mesmo. Aderência à norma. Adesão voluntária, intimamente desejada. Um mesmo vocabulário, um mesmo ideal, um mesmo desejo. Mesmo que seja para experiências tão díspares. Colamento do ideal moral das condutas sexuais com a conjugalidade. Uma 
moralidade que carrega valores de fidelidade e defesa da família. Um ideal moral que "deixa órfão de aprovação muitos outros pleitos eróticos" (COSTA, 1992, p.80). Criação de novas utilidades; utilidades mais úteis. Utilidades para certas inclinações homoeróticas. Condutas que são conduzidas dessa maneira; possibilidades ordenadas; normas que serpenteiam e acolhem multiplicidades.

Tudo se passando junto com a inclusão dessas pessoas.

Inclusão esta, que se configura uma prática política de governamentalidade, aponta Lopes (2009). Melhor dizendo, um conjunto de práticas inserido em um contexto neoliberal, responsável também pela constituição de formas de vida "cada vez mais conduzidas para princípios de mercado e de autorreflexão, em que os processos de ensino/aprendizagem devem ser permanentes" (p.154). Inclusão que fala da ampliação de condições de sustentabilidade de si, de um si atravessado pelo capital e pelo neoliberalismo. Este é o jogo. Um jogo que deve ser jogado por todos. Um jogo que deve ser ensinado permanente também pelo cinema. Um jogo que deve ser desejado por todos. E um desejo que deve ser ensinado. De forma diuturna.

Mas quem se quer incluir? Excluídos, ora. Aqueles que

não são capturados pelo sistema e serviços do Estado, embora estejam capturados pela governamentalidade do Estado. Não são capturados simplesmente porque são invisíveis. Invisíveis não porque não são vistos nas ruas, mas por estarem capturados pela governamentalidade, não causam problemas, não geram ruídos, não perturbam a ordem estabelecida para a população (LOPES, 2009, p.158).

A luta pela inclusão, nesse sentido, significa também trazer aqueles que desviam para dentro das fronteiras da normalidade, abafando os grunhidos que ousaram ter. Uma melhor possibilidade de controle, decerto. A criação de novos Estados; o Estado de si, em si. O autogoverno, a autocondução. Um sequestro de si operado por si mesmo. 
A essa altura, poderíamos pensar que não há saídas, ou, se há, elas são poucas e insuficientes por demais. Uma possível superdeterminação do poder; tudo tende a ser capturado, sempre cooptado e enredado pelas tramas do poder. Mas há de se lembrar que onde há poder, há necessariamente liberdade; sempre há possibilidades de resistir. "Sempre há possibilidade, em um determinado jogo de verdade, de descobrir alguma coisa diferente e de mudar mais ou menos tal regra, e mesmo eventualmente todo o conjunto do jogo de verdade" (FOUCAULT, 2004b, pp.282-283). Um pouco de possível, senão eu sufoco, diria Deleuze.

Tomadas como jogos estratégicos entre liberdades, isto é, jogos nos quais cada um tenta conduzir a conduta dos outros, as relações de poder se constituem necessariamente em relações entre homens livres. Algo a nos lembrarmos.

No exercício da liberdade, Foucault (2004a, 2004b) destaca a importância o cuidado de si. Cuidar de si; ocupar-se de si mesmo. Não simplesmente um princípio de vida, mas uma prática constante. Mais do que uma atitude, uma atividade real, concreta. Uma tarefa prioritária. Uma tarefa que exige se conhecer e se formar, superando a si mesmo, dominando em si "os apetites", desejos que poderiam arrebatá-lo. Dominar desejos que o dominariam. Uma maneira de entrar em um jogo de verdade, verdade de si. Uma atenção a detalhes, a pormenores, àquilo que parece não ter importância. Detalhes a serem administrados, não julgados e punidos. Um cuidado de si que implica o cuidado dos outros; quer dizer, governarse bem para bem governar, conduzir a família, os outros, a cidade. Um cuidado que se faz na relação com o outro, com o mestre e suas lições.

Em exercício de liberdade. Mas uma liberdade que pouco tem a ver com um estado natural a ser encontrado em lugares recônditos de nossa existência, íntima e auto-regulatória.

Pois bem, se falamos em inclusão, ater-se a efeitos parece pouco. Quando outrora falamos de rupturas necessárias para a construção de práticas inclusivas (MACHADO et al., 2009), falávamos em experimentações e criações de novas sensibilidades. Falamos, então, na 
interferência no campo de forças na qual modos de existência são produzidos e valorados, interferência capaz de das vazão a diferenças emergentes. Algo que implica, nas palavras de Rolnik (1996, p.121) “a criação de contornos subjetivos singulares e efêmeros - e portanto não generalizáveis - já que singularidades e efêmeras são as misturas de forças/fluxos de que é feita cada diferença que vai se produzindo ao longo da existência”.

Nesse exercício de si, a inculcante tarefa de construção de identidades é frequente. Mas nem tudo é captura. Butler (2007, p.156) nos traz um norte em um campo tão minado, de tantas capturas: as "desidentificações coletivas podem facilitar uma recontextualização da questão de se saber quais corpos pesam e quais corpos ainda devem emergir como preocupações que possam ter um peso crítico". Há possibilidades de estranhamentos, de sentir-se, de uma poltrona qualquer, perdido em terras desconhecidas. Há possibilidade de criação de novos corpos, novos pesos. O filme francês Johan é uma dessas ocasiões em que o chão nos é tirado.

No enredo do filme, acompanhamos Philippe às voltas com a direção de um filme sobre sua história de amor com Johan, que está preso. Um filme sobre a intensidade desse amor; é isso que ele pretende captar, pouco conseguindo.

Em seu cotidiano de filmagens, busca por atores certos para o estrelar. Muitos interpretam Johan e Philippe. Muitos são Johan e muitos são Philippe. Uma quebra em uma suposta identidade monolítica. Uma aposta na multiplicidade. De forças. Uma aposta que significa também apostar no devir, isto é, na possibilidade de tornar-se outro, de outrar-se. Da mesma forma, uma fronteira escorregadia entre o filme que assistimos e o filme que é filmado por Philippe, que constantemente se misturam. Fantasia que se confunde com a fantasia. E com a realidade; o filme Johan também é dirigido por Philippe, que interpreta a si mesmo no filme que assistimos. Mas, se tudo é invenção, não se é problema não sabermos "ao certo" que filmes assistimos. Multiplicidade. Multiplicidades que correm para todos os lados. 
No cotidiano de Philippe, encontros com outros homens. Encontros com homens em praças e parques públicas. Olhares, sorrisos, piscadelas. Poucas palavras. Da praça para o apartamento. Sexo. Sexo em banheiros públicos. Sexo em ruas e becos escuros. A experimentação de novas práticas, de novos mundos. Fisting, cock ring, poppers, drogas, sado-masoquismo. Deriva. Sexo, muito sexo. Invenção de novas possibilidades de amar, de se ter prazer, de se relacionar.

Uma história de amor. Philippe ama com tamanha intensidade, como vemos nas cartas enviadas para Johan. Conflito algum entre esse amor sem tamanho e os encontros fortuitos que tem frequentemente.

É isso que nos tira o chão, que assusta. Uma trama atravessada pelo caos. Pela quebra de fronteiras. Outras possibilidades. Pela possibilidade de tornar-se outro, de outrar-se; de resistir a pessoalidades. Louro (2009), ao discutir e caracterizar o queer nos ajuda a pensar o que incomoda. Incomoda o jeito transgressivo de estar no mundo e de pensar o mundo. $\mathrm{O}$ movimento, a não-acomodação, a ambigüidade, o não-lugar, o estar-entre. $\mathrm{O}$ deslize. $\mathrm{O}$ impensável. Indo mais além, parece, por exemplo, impensável amar alguém e transar com tantos outros. Parece impensável a utilização de partes do corpo, como um punho, para se sentir prazer. Parece impensável usar o próprio corpo de forma quase aleatória, tirando prazer do mais improvável. Parece impensável, insuportável, inadmissível.

Aqui, não estamos imbuídos da ideia de que há, por si só, um cinema bom e um cinema ruim. A valoração de um filme se relaciona, a nosso ver, com as possibilidades que temos diante dele. O que um filme nos faz fazer? Esta é uma pergunta de extrema importância a ser feita. O que fazemos de nós quando assistimos um filme? Como vimos utilizando filmes para combater em nós a afirmação de identidades, estáveis, estagnadas, delimitadas? Perguntas que deixam claro que nosso combate não é contra um tipo de cinema, por exemplo; o combate que queremos tecer é entre. Um combate entre que possibilita que o cinema seja 
usado para pensarmos o que estamos a fazer de nós mesmos. O que estamos a fazer conosco. Entre forças, entre relações, pois, como conjectura Foucault (1994, p.239),

Talvez, o objetivo hoje em dia não seja descobrir quem somos, mas recusar o que somos. Temos que imaginar e construir o que poderíamos ser para nos livrarmos deste "duplo constrangimento" político, que é a simultânea individualização e totalização e própria às estruturas do poder moderno.

O exercício de si permanece; há de permanecer. Não em busca de uma conversão ou do auto-deciframento. Um exercício de si no qual se efetue um combate entre a cumplicidade que nos liga ao modo que aprendemos a existir e a nos aprisionar (mesmo quando essas prisões são investidas de ares de liberdade). Um combate que nos aproxime de potências desejantes, que aproxime a vida daquilo que ela pode, que a expanda. Um combate que exige criação, uma postura criativa, que amplie nossas possibilidades de existir, de inventar realidades, desejos, nortes.

Que suba o letreiro e se acendam as luzes. 


\section{REFERÊNCIAS}

ADORNO, Theodor W. \& HORKHEIMER, Max. Dialética do esclarecimento: fragmentos filosóficos. Rio de Janeiro: Jorge Zahar Ed., 1985.

AGAMBEN, Giorgio. Infância e história: destruição da experiência e origem da história. Belo Horizonte: Editora UFMG, 2005.

. O que é o contemporâneo? e outros ensaios. Chapecó: Argos, 2009.

AQUINO, Julio Groppa. Sobre a lógica do controle na atualidade: o caso Stuart Little. In: SETTON, M.G.J. A cultura de mídia na escola: ensaios sobre cinema e educação. São Paulo: Annablume: USP, 2004, pp.137-151.

. Instantâneos da escola contemporânea. Campinas: Papirus, 2007.

\& RIBEIRO, Cintya Regina. Processos de governamentalização e a atualidade educacional: a liberdade como eixo problematizador. Educação \& Realidade, v.34, n.2, 2009, pp.57-71. http://www.seer.ufrgs.br/index.php/educacaoerealidade/issue/view/765. Acesso em 20 nov. 2010.

ARIÈS, Phillippe. Reflexões sobre a história da homossexualidade. In: $\&$ BÉJIN, A. (Orgs.). Sexualidades ocidentais: contribuições para a história e para o sociologia da sexualidade. $3^{\text {a }}$ Ed. São Paulo: Brasiliense, 1987, pp. 77-92.

BADIOU, Alain. El cine como experimentación filosófica. In: YOEL, Gerardo (Comp.). Pensar el Cine I: imagen, ética y filosofia. Buenos Aires: Manntial, 2004, pp. 2381.

BALÁZS, Bela. Der sichtbare mensch (O homem visível). In: XAVIER, I. (org.). A experiência do cinema: antologia, $4^{\mathrm{a}}$ Ed, Rio de Janeiro: Graal, 1923 [1983], pp.77-83.

BARROS, Regina Benevides. Grupo: a afirmação de um simulacro. Tese (doutorado). PUC-SP, 1994.

BENJAMIN, Walter. A obra de arte na era de sua reprodutibilidade técnica. In: , Magia e técnica, arte e política: ensaios sobre literatura e história da cultura. 7 ed. São Paulo: Brasiliense, 1936 [1994] (Obras escolhidas, volume 1), pp.165-196.

BESSA, Karla. Os festivais GLBT de cinema e as mudanças estético-políticas na constituição da subjetividade. Cadernos Pagu, n.28, jan-jun 2007, pp. 257-283. Disponível em http://www.scielo.br/scielo.php?script=sci_arttext\&pid=S0104-83332007000100003\&lng=pt\&nrm=iso Acesso em 01 fev. 2011.

BOURDIEU, Pierre. Algumas questões sobre o movimento gay e lésbico. In: A dominação masculina. $9^{a}$ Ed. Rio de Janeiro: Bertrand Brasil, 2010, pp.143-149. 
BUTLER, Judith. Corpos que pesam: sobre os limites discursivos do "sexo". In:

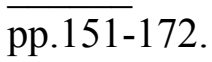

O corpo educado: pedagogias da sexualidade. Belo Horizonte: Autêntica, 2007,

CANGUILHEM, Georges. O normal e o patológico. Rio de Janeiro: Forense Universitária, 2009.

CASTRO, Edgardo. Vocabulário de Foucault - um percurso pelos seus temas, conceitos e autores. Belo Horizonte: Autêntica, 2009.

COIMBRA, Cecília Maria Bouças. Classes perigosas: uma pequena genealogia. In: FERREIRA, G. e FONSÊCA, P. (orgs.). Conversando em casa. Rio de Janeiro: 7Letras, 2000, pp. 56-65.

COSTA, Jurandir Freire. A inocência e o vício: estudos sobre o homoerotismo. Rio de Janeiro: Relume-Dumará, 1992.

DELEUZE, Gilles. Conversações. São Paulo: Editora 34, 1992.

DELEUZE, Gilles. \& GUATTARI, Félix. Introdução: rizoma. In: Mil platôs - capitalismo e esquizofrenia. Volume 1. São Paulo: Ed. 34, 1995, pp. 11-37.

DUARTE, Rodrigo. Indústria cultural hoje. In: DURÃO, F.A., ZUNIN, A. \& VAZ, A.F. (orgs.). A indústria cultural hoje. São Paulo: Boitempo, 2008, pp.97-110.

EISENSTEIN, Serguei M. Montagens de atrações. In: XAVIER, I. (org.). A experiência do cinema: antologia, $4^{\mathrm{a}}$ Ed, Rio de Janeiro: Graal, 1923 [1983], pp.187-198.

FABRIS, Eli Henn. Cinema e Educação: um caminho metodológico. Educação \& Realidade, Porto Alegre, v.33, n.1, 2008. Disponível em http://www.seer.ufrgs.br/index.php/educacaoerealidade/article/view/6690. Acessos em 01 mai. 2010.

FERNANDES, Wânia Ribeiro \& SIQUEIRA, Vera Helena Ferraz. O cinema como pedagogia cultural: significações por mulheres idosas. Estudos Feministas, v.18, n.1, Florianópolis, 2010, pp. 101-119. Disponível em http://www.scielo.br/scielo.php?script=sci arttext\&pid=S0104-026X2010000100006\&lng=pt\&nrm=iso. Acessos em 15 dez. 2010.

FISHER, Rosa Maria Bueno. Mídia e educação da mulher: uma discussão teórica sobre modos de enunciar o feminino na TV. Estudos Feministas. 2001, pp.586-599. Disponível em $\quad$ http://www.scielo.br/scielo.php?script=sci_arttext\&pid=S0104$\underline{026 X 2001000200015 \& \operatorname{lng}=p t \& n r m=i s o}$. Acessos em 15 dez. 2010.

. O dispositivo pedagógico da mídia: modos de educar na (e pela) TV. Educação e Pesquisa, v.28, n.1, São Paulo, 2002, pp.151-162. Disponível em http://www.scielo.br/scielo.php?script=sci_arttext\&pid=S1517-97022002000100011\&lng=pt\&nrm=iso Acessos em 10 dez. 2010. 
. Pequena Miss Sunshine: para além de uma subjetividade exterior. ProProsições, Campinas, v. 19, n. 2, ago. 2008a. Disponível em http://www.scielo.br/scielo.php?script=sci arttext\&pid=S0103-73072008000200005\&lng=pt\&nrm=iso.

Acessos em 08 abr. 2010.

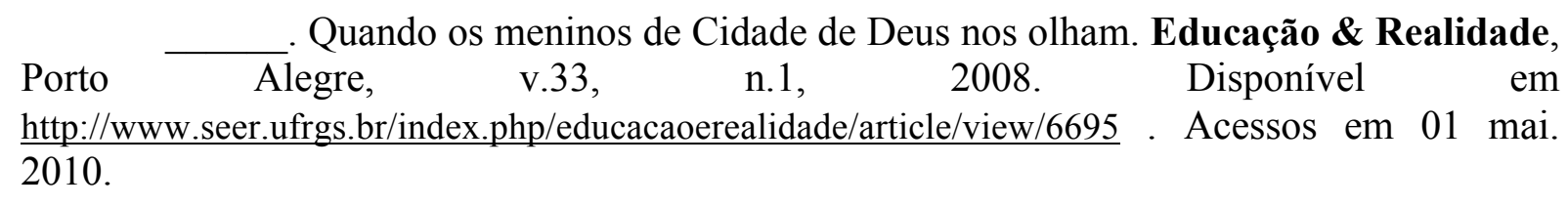

FOUCAULT, Michel. A verdade e as formas jurídicas. Rio de Janeiro: Nau, $3^{\text {a }}$ ed, 1973 [2003].

. Vigiar e punir. Petrópolis: Ed. Vozes, 5ª ed, 1975 [1987].

. Microfísica do poder. Rio de Janeiro: Ed. Graal, 24ª ed,1979.

[2006].

. O nascimento da clínica. Rio de Janeiro: Forense Universitária, 6 6 ed, 1980

. História da sexualidade I: a vontade de saber. São Paulo: Graal, 18 ed, 1988.

. O sujeito e o poder. In: Dreyfus, H.; Rabinow, P. Michel Foucault, uma trajetória filosófica. Rio de Janeiro: Forense Universitária, 1995.

. A ordem do discurso. São Paulo: Loyola, 9ª ed, 1996.

. Em defesa da sociedade. São Paulo: Martins Fontes, 1999.

. Um discurso sobre os prazeres do sexo; Nietzche, Freud e Marx; Theatrum philosoficum. São Paulo: Landy Editora, 2000.

. Dits et écrits II. 1976-1988. Paris: Gallimard, 2001.

. Tecnologias de si. Verve, n.6, pp.321-360, 2004a.

. A ética do cuidado de si como prática da liberdade. In:

sexualidade, política. (Ditos e escritos V). Rio de Janeiro: Forense Universitária, 2004b.

. Segurança, território, população. São Paulo: Martins Fontes, 2008a.

. Aula de 21 de março de 1979. In: . Nascimento da biopolitica. São Paulo: Martins Fontes, 2008b.

FRANCO, Renato. A televisão segundo Adorno: o planejamento industrial do “espírito objetivo". In: DURÃO, F.A., ZUNIN, A. \& VAZ, A.F. (orgs.). A indústria cultural hoje. São Paulo: Boitempo, 2008, pp.111-122. 
GREEN, James N. "Mais amor e mais tesão": a construção de um movimento brasileiro de gays, lésbicas e travestis. Cadernos Pagu, vol.15, 2000, pp.271-295. Disponível em http://www.pagu.unicamp.br/node/61. Acesso em 05 fev. 2011.

GUATTARI, Félix. \& ROLNIK, Suely. Micropolítica: cartografias do desejo. 7 ed. Petrópolis: Vozes, 2005.

HULLOT-KENTOR, Robert. Em que sentido exatamente a indústria cultural não existe mais. In: DURÃO, F.A., ZUNIN, A. \& VAZ, A.F. (orgs.). A indústria cultural hoje. São Paulo: Boitempo, 2008, pp.17-27.

LOPES, Maura Corcini. Políticas de inclusão e governamentalidade. Educação \& Realidade, v.34, n.2, 2009, pp.153-169. Disponível em http://seer.ufrgs.br/educacaoerealidade/article/view/8297/5536. Acesso em 20 fev. 2011.

LOUREIRO, Robson. Educação, cinema e estética: elementos para uma reeducação do olhar. Educação \& Realidade, Porto Alegre, v.33, n.1, 2008. Disponível em http://www.seer.ufrgs.br/index.php/educacaoerealidade/article/view/6691 . Acessos em 01 mai. 2010.

LOURO, Guacira Lopes. Gênero, sexualidade e educação: uma perspectiva pósestruturalista. Petrópolis: Vozes, 1997.

. Pedagogias da sexualidade. In:

sexualidade. Belo Horizonte: Autêntica, 2007, pp.7-34.

O corpo educado: pedagogias da

Foucault e os estudos queer. In: RAGO, M. \& VEIGA-NETO, A. (orgs.).

Para uma vida não-fascista. Belo Horizonte: Autêntica, 2009, pp.135-142.

. O cinema como pedagogia. In: LOPES, E.M.T., FARIA FILHO, L.M \& VEIGA, C.G. (Org.). 500 anos de educação no Brasil, $4^{\mathrm{a}}$ Ed, Belo Horizonte: Autentica, 2010, pp. 423-466.

MACHADO, Adriana Marcondes; ALMEIDA, Izabel \& SARAIVA, Luís Fernando de Oliveira. Rupturas necessárias para uma prática inclusiva. In: CONSELHO Federal de Psicologia. Educação inclusiva: experiências profissionais em psicologia. Brasília: Conselho Federal de Psicologia, 2009, pp.21-35.

MAIA, Antônio Cavalcanti Maia. Foucault e Adorno: mapeando um campo de convergências. In: RAGO, M., ORLANDI, L.B.L. \& VEIGA-NETO, A. Imagens de Foucault e Deleuze: ressonâncias nietzschianas. Rio de Janeiro: DP\&A, 2005, $2^{\mathrm{a}} \mathrm{Ed}$, pp.6384.

MASSCHELEIN, Jan. E-ducando o Olhar: a necessidade de uma pedagogia pobre. Educação \& Realidade, Porto Alegre, v.33, n.1, 2008. Disponível em http://www.seer.ufrgs.br/index.php/educacaoerealidade/article/view/6685/3998 . Acessos em 01 mai. 2010. 
MAUERHOFER, Hugo. A psicologia da experiência cinematográfica. A atenção. In: XAVIER, I. (org.). A experiência do cinema: antologia, $4^{\mathrm{a}}$ Ed, Rio de Janeiro: Graal, 1949 [1983], pp.375-380.

METZ, Christian. História / Discurso (nota sobre dois voyeurismos). In: XAVIER, I. (org.). A experiência do cinema: antologia, 4 ${ }^{\mathrm{a}}$ Ed, Rio de Janeiro: Graal, 1975 [1983], pp.403-410.

MIRANDA, Luciana Lobo. Subjetividade: a (des)construção de um conceito. In: JOBIM E SOUZA, S. (Org.). Subjetividade em questão: a infância como crítica da cultura. Rio de Janeiro: 7 Letras, 2005, pp.29-46.

MONTEIRO, Maria Zeneide. Afinal, de que subjetividade estamos falando? Subjetividades Contemporâneas. São Paulo: Instituto Sedes Sapientiae, n.1, 1997, pp.2627.

MORENO, Antônio. A personagem homossexual no cinema brasileiro. $2^{\mathrm{a}}$ Ed. Rio de Janeiro: Funarte; Niterói: EdUFF, 2002.

MOYSÉS, Maria Aparecida Affonso. A institucionalização invisível: crianças que não-aprendem-na-escola. Campinas: Mercado de Letras; São Paulo: FAPESP, 2001.

MUNSTERBERG, Hugo. A atenção. In: XAVIER, I. (org.). A experiência do cinema: antologia, $4^{\mathrm{a}}$ Ed, Rio de Janeiro: Graal, 1983, pp.27-35.

PAIVA, Antônio Crístian Saraiva. Reserva e invisibilidade: a construção da homoconjugalidade numa perspectiva micropolítica. In: GROSSI, M.P.; UZIEL, A.P. \& MELlO, L. (Org.). Conjugalidades, parentalidades e identidades lesbicas, gays e travestis. Rio de Janeiro: Garamond, 2007, pp. 23-46.

PATTO, Maria Helena Souza. Exercícios de indignação: escritos de educação e política. São Paulo: Casa do Psicólogo, 2005.

2003.

PELBART, Peter Pal. Vida capital: ensaios de biopolítica. São Paulo: Iluminuras,

PERLONGHER, Nestor. O negócio do michê: a prostituição viril em São Paulo. São Paulo: Ed. Fundação Perseu Abramo, 2008.

$39-45$.

. O desaparecimento da homossexualidade. SaúdeLoucura, n.3, 1991, pp.

POLLAK, Michael. A homossexualidade masculina, ou: a felicidade do gueto? In: ARIÉS, P. \& BÉJIN, A. (Orgs.). Sexualidades ocidentais: contribuições para a história e para o sociologia da sexualidade. $3^{\text {a }}$ Ed. São Paulo: Brasiliense, 1987, pp. 54-76.

PUDOVKIN, V. Métodos de tratamento do material (montagem estrutural). In: XAVIER, I. (org.). A experiência do cinema: antologia, $4^{\mathrm{a}}$ Ed, Rio de Janeiro: Graal, 1926 [1983], pp.57-65. 
ROLNIK, Suely. Guerra dos gêneros \& guerra aos gêneros. Estudos Feministas, n.1, 1996, pp.118-123. Disponível em http://www.periodicos.ufsc.br/index.php/ref/article/view/16660/15229. Acesso em 25 fev.2011.

ROSE, Nikolas. Governando a alma: a formação do eu provado. In: SILVA, T.T. (org.) Liberdades reguladas. Petrópolis: Vozes, 1998, pp. 30-45. 2001, pp. $\overline{\text { 33-57. }}$

. Como se deve fazer a história do eu? Educação \& Realidade, v.26, n.1,

ROUDINESCO, Elisabeth. A família do futuro. In:

A família em desordem. Rio de Janeiro: Zahar, 2003, pp.181-199.

SARAIVA, Luís Fernando de Oliveira. Olhares em foco: tensionando silenciamentos. In: Souza, B.P. Orientação à queixa escolar. São Paulo: Casa do Psicólogo, $2^{\mathrm{a}}$ ed, 2010, pp. 59-78.

SAYÃO, Rosely \& AQUINO, Julio Groppa. Família: modos de usar. Campinas: Papirus, 2006.

SEDGWICK, Eve Kosofsky. A epistemologia do armário. Cadernos Pagu, vol.28, jun. 2007, pp.19-54. Disponível em http://www.scielo.br/scielo.php?script=sci_arttext\&pid=S0104-

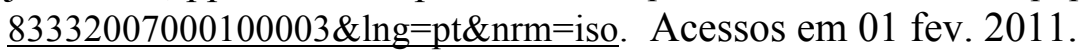

SWAIN, Tania Navarro. Feminismo e lesbianismo: a identidade em questão. Cadernos Pagu, vol. 12, 1999, pp.109-120. Disponível em http://www.pagu.unicamp.br/node/58. Acessos em 01 fev. 2011.

VASCONCELLOS, Jorge. A Pedagogia da Imagem: Deleuze, Godard - ou como produzir um pensamento do cinema. Educação \& Realidade, Porto Alegre, v.33, n.1, 2008. Disponível em http://www.seer.ufrgs.br/index.php/educacaoerealidade/article/view/6692 . Acessos em 01 mai. 2010.

WEEKS, Jeffrey. O corpo e a sexualidade. In: O corpo educado: pedagogias da sexualidade. Belo Horizonte: Autêntica, 2007, pp.35-82.

XAVIER, Ismail. Cinema: revelação e engano. In: O olhar e a cena melodrama, Hollywood, Cinema Novo, Nelson Rodrigues. São Paulo: Cosac \& Naif, 2003, pp. 31-57.

Paulo: Paz e Terra, 2008.

. O discurso cinematográfico: a opacidade e a transparência. $4^{\mathrm{a}}$ ed., São 


\section{Filmes analisados}

BELEZA Americana (American Beauty). Direção: Sam Mendes. Produção: Alan Ball, Bruce Cohen. Intérpretes: Kevin Spacey, Annette Bening, Thora Birch, Wes Bentley, Mena Suvari, Peter Gallagher, Chris Cooper. Roteiro: Alan Ball. EUA. 1999. 1 DVD (121 min), color.

JOHAN (Johan, mon été 75). Direção: Philippe Vallois. Intérpretes: Marie-Christine Weill, Patrice Pascal, Philippe Vallois, Laurent Laclos, Georges Barber, Jean-Lou Duc, Karl Forest, Pierre Commoy, Manolo Rosales, Alexandre Grecq, Nicole Rondy, Éric Guadagnan, Walter Manley, Jacques Léon, Thierry Loret. França. 1976. 1 DVD (80 min), color.

LONGE do Paraíso (Far from heaven). Direção: Todd Haynes. Produção: Jody Patton, Christine Vachon. Intérpretes: Julianne Moore, Dennis Quaid, Dennis Haysbert, Patricia Clarkson, Viola Davis, James Rebhorn, Bette Henritze e outros. Roteiro: Todd Haynes. EUA/ França. 2002. 1 DVD (107 min), color.

MENINOS não choram (Boys don’t cry). Direção: Kimberly Peirce. Produção: John Hart, Eva Kolodner, Jeff Sharp, Christine Vachon. Intérpretes: Hilary Swank, Chloe Sevigny, Peter Sarsgaard, Alison Folland e outros. Roteiro: Andy Bienen. EUA. 1999. 1 DVD (116 min), color.

MILK, a voz da igualdade (Milk). Direção: Gus Van Sant. Produção: Bruce Cohen, Dan Jinks, Michael London. Intérpretes: Sean Penn, Josh Brolin, Emile Hirsch, James Franco, Diego Luna, Brandon Boyce, Kelvin Yu, Lucas Grabeel e outros. Roteiro: Dustin Lance Black. Fotografia: Harris Savides. EUA. 2008. 1 DVD (128 min), color.

O SEGREDO de Brokeback Moutain (Brokeback Moutain). Direção: Ang Lee. Produção: Diana Ossana e James Schamus. Intérpretes: Jake Gyllenhaal, Heath Ledger, Michelle Williams, Anne Hathaway, Randy Quaid e outros. Roteiro: Larry McMurtry, Diana Ossana, baseado em conto de E. Annie Proulx. EUA. 2005. 1 DVD (130 min), color.

PRECIOSA, uma história de esperança (Precious: Based On the Novel Push by Sapphire). Direção: Lee Daniels. Produção: Lisa Cortes, Tom Heller, Lee Daniels. Intérpretes: Gabourey Sidibe, Mo'Nique, Paula Patton, Mariah Carey, Lenny Kravitz e outros. Roteiro: Geoffrey Fletcher. EUA. 2009. 1 DVD (110 min), color. 


\section{Bibliografia CONSUltada}

AMARAL, Ligia Assumpção. Conhecendo a deficiência (em companhia de Hércules). São Paulo: Robe Editorial, 1995.

COSTA, Marisa Vorraber (org). Caminhos investigativos I: novos olhares na pesquisa em educação. 3 ed. Rio de Janeiro: Lamparina, 2007.

DELEUZE, Gilles. \& GUATTARI, Félix. Mil platôs - capitalismo e esquizofrenia. São Paulo: Ed. 34, 1995.

FUGANTI, Luiz. Biopoder em Foucault. Anotações de aula. Curso ministrado na Escola Nômade de Filosofia, São Paulo, 2010.

Biopolítica, governamentalidade e cuidade de si em Foucault. Anotações de aula. Curso ministrado na Escola Nômade de Filosofia, São Paulo, 2011.

GROSSI, Miriam; UZIEL, Anna Paula; MELLO, Luiz (orgs.). Conjugalidades, parentalidades e identidades lésbicas, gays e travestis. Rio de Janeiro: Garamond, 2007.

RAMOS DO O, Jorge Ramos. A crítica pós-estruturalista e a emergência de uma escrita científica de si: os desafios de Barthes, Deleuze, Derrida e Foucault. Anotações de aula. Disciplina ministrada na Faculdade de Educação da USP. 2009. 2000.

LOURO, Guacira Lopes. Currículo, gênero e sexualidade. Porto: Porto Editora,

SETTON, Maria da Graça Jacintho (org.) A cultura da mídia na escola: ensaios sobre cinema e educação. São Paulo: Annablume: USP, 2004.

XAVIER, Ismail. (org.). A experiência do cinema: antologia, $4^{\mathrm{a}} \mathrm{Ed}$, Rio de Janeiro: Graal, 1983. 